Historic, Archive Document

Do not assume content reflects current scientific knowledge, policies, or practices. 

Flowers + Seeds

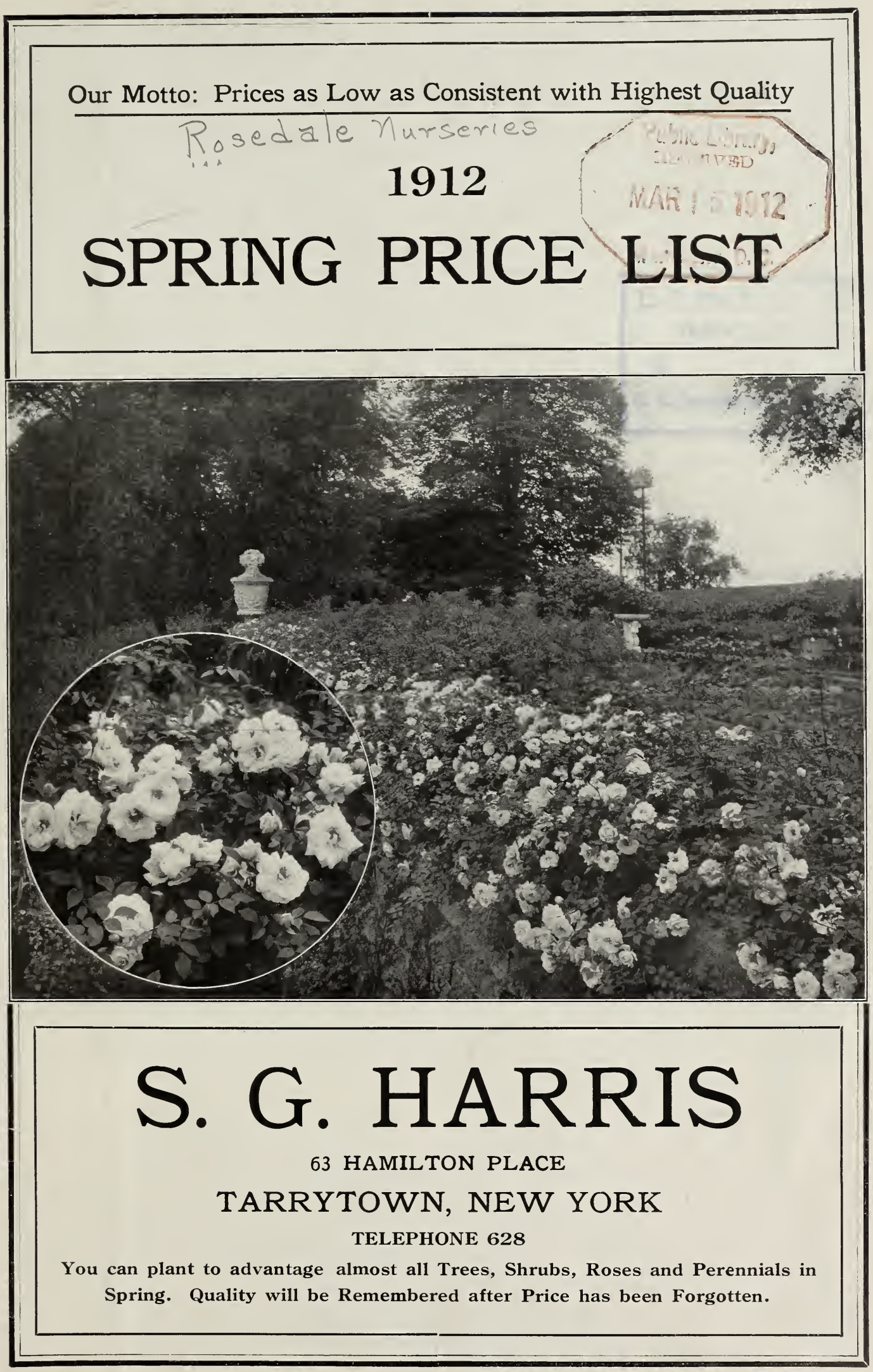




\section{Remarks To Customers}

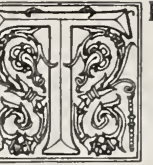

HANKING my customers for their generous patronage for the past year, I am pleased to announce that we are better prepared than ever to furnish strictly high-grade stock in all departments. We furnish annually many of the finest estates, parks and cemeteries in the country, which is proof that our goods are satisfactory, both in quality and price. We solicit a trial order from those who have not previously had our plants.

Before Ordering, please send to us for quotations, if you do not find desired plants printed herein. Lowest rates will be given on trees by the hundred and thousand and in car-load lots.

Early Orders. - Much time can be saved in the busy shipping season if customers will send in early orders. Spring orders should be in by March 15; and for fall by October 1. Catalogue of bulbs will be sent in midsummer to all whose names appear on our list.

No Substitutions are made without permission. It is well in ordering varieties of fruit and ornamental trees to name possible substitutes, especially in late orders, since some varieties are likely to be sold out.

Express.-Since Express Companies deliver plants, seeds and bulbs at a reduction of 20 per cent from the merchandise rate, we advise all shipments of small orders by that method. We guarantee safe arrival by express.

Plants by Express.-We always add liberal extras to help defray charges. We make no charge for boxes or packing. Prices are f. o. b. Tarrytown.

Remittances should be by express money order, post-office money order or bank draft.

No Accounts Opened for Less than \$10.-Less than this amount must be accompanied by remittance, unless a customer has a regular account.

Orders from a new customer must be accompanied by remittance or satisfactory reference.

Name and Address.-Please remember to write your name, post-office, county, and state; also (when necessary) give number of street distinctly; also give the name of your express company.

Gardeners.-I keep a list of gardeners seeking employment, and shall be pleased to recommend to customers men of proper qualifications.

"It is my belief that the art of cultivating flowers must be regarded as no less important than the art of sculpture or painting, because the flowers form the most beautiful part of nature."

\section{Hints for Proper Planting}

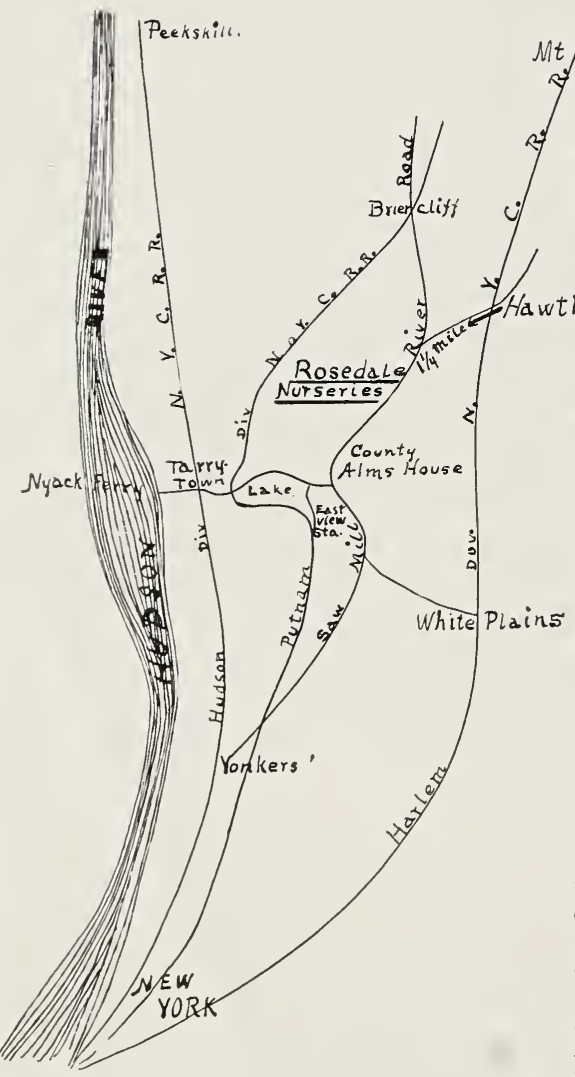

To properly plant a tree or shrub is a very easy Mt $k$ isco matter if one will carefully follow these four rules:

FIRST.-Dig the holes large enough to admit the roots spread out in their natural position, and deep enough to allow the plant to stand at the same depth it stood in the nursery. More trees are lost by deep planting than by shallow.

SECOND.-Use no fertilizer, but sprinkle fine soil among the roots, shaking the tree a little if necessary, or using the hand, if the fibrous roots are very numerous, so that every root may come in contact with the soil.

THIRD.-When the roots are well covered, the earth should be tramped, or tamped, as firm as a post. Put in more earth and tamp again. The last two or three inches of earth should not be tamped, leaving it loose for the rain to be taken in. Do not round up the earth about the tree, lest the water run off. If the weather is dry early in fall or late in the spring, water may be poured in about the tree; otherwise it is seldom necessary.

FOURTH.-Give the tree a good mulching to hold the moisture.

\section{Trees and Shrubs for Nursery Planting}

Where large future plantings are to be made in cemeteries, parks or large estates, the economy of growing trees for a year or more in the nursery row, from which they are readily transplanted to other parts of the grounds, is evident. The cost of packing, transportation, etc., is hereby reduced to the minimum, and the cost of the plants is inconsiderable.

Having best facilities for furnishing nursery grown, twice-transplanted stock, we solicit opportunity to quote prices to those intending large plantings. 


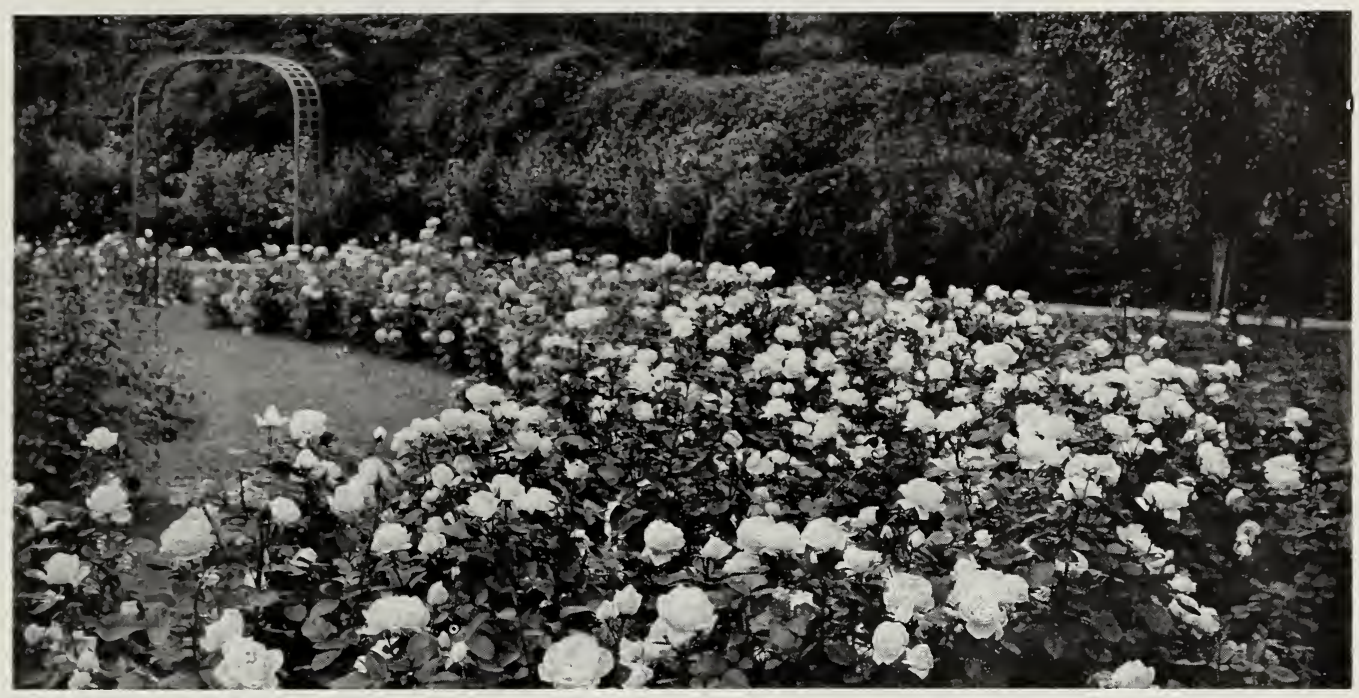

View of Two Beds in Helen Gould's Superb Rose Garden, Tarrytown, New York

\section{NEW ROSES}

All our Roses are field grown, heavy two-year-old plants, no pot-plants; no Holland stock; no second size. For prices see order sheet.

We take pleasure in offering a select list of Roses, heavy plants which will easily pay for themselves in bloom the first year. Why not have the best, since a good plant requires no more space or care than a poor one, except to pick the extra bloom? A Rose-garden cannot be made of weeds. Of thousands of varieties, not more than one hundred are worth growing in any given locality, unless one has a very large Rose-garden. Some varieties do well in one section, some in another. When we say we have only first-olass varieties and first-class plants of all colors of Roses, including several of the best yellow sorts, we are prepared to back up our statements; and, as the Rose has long been acknowledged the "queen of flowers," and has held its place as such among nearly all flower-lovers, we have spared no pains to provide our customers with heavy, twoyear old plants, which will produce grand blooms the first season. We offer several thousand plants, grown by Dickson Sons, of Ireland, including Killarney, Mildred Grant, Bessie Brown, etc. No Holland stock. That we Dickson Sons, of Ireland, including Killarney, Mildred Grant, Bessie Brown, etc. No Holland stock. That we
have succeeded in pleasing the public may be seen from the increased demand and the many letters of commendation from our customers.

\section{Budded vs. Own Root Plants.}

Growers are apt to argue for their own method of propagation. An impartial opinion by an eminent rosarian may be found in an excellent article by Dr. Robert Huey in the March, 1905, number of "Country Life in America." Speaking of budded plants, he says: "They are much more vigorous, produce finer blooms, come into bearing sooner and last just as long, if not longer." $\mathrm{He}$ further states that "many fine varieties are utterly worthless unless budded."

\section{Novelties of 1911 and 1910}

Carine. (H. T.) The many phases of color depicted in the development of this exquisite rose are almost too intricate to describe, including as they do, orangecarmine, blush-buff, creamy-fawn and coppery-salmon. The growth is vigorous, erect and branching, flowering in great profusion.

Duchess of Westminster. (H. T.) A peerless Tea-like Rose, with beautifully smooth and massive petals. The blooms are very large, full and perfectly formed, with high, pointed center; very sweetly perfumed. The color is a dainty, clear rose-madder. The growth is vigorous, erect and of very free flowering habit.

Mabel Drew. (H. T.) A truly magnificent Rose, superb in every respect; exquisitely shaped, with smooth circular petals of great substance. The blooms are large and full. The color is deep cream in the young state passing to intense canary-yellow in the center, as the bloom develops. The growth is vigorous; the perfume deliciously refreshing. Awarded a gold medal at the National Rose Society of London.

Mrs. Chas. Curtis Harrison. (H. T.) Deep crimson pink on front of petals, crayoned deep crimson carmine on reverse side; a warm color, blooms large, full and globular; petals smooth, circular and of great substance: free-flowering, very highly perfumed, absolutely distinct, fine.

Mrs. Foley Hobbs. (Tea.) Delicate, ivory white, faintly tinged clear pink on edge of petals; blooms large, exquisite form, perfect finish; petals thick and shell shaped, floriferous, deliciously tea perfumed, exceptionally fine for exhibition. Superb. Gold Medal, N. R. S.

Mrs. Fred Straker. ( H. T.) Orange-crimson in the bud, developing as the bloom expands to silvery-fawn on front of petals, and delicate orange-pink on back buds long and elegant, with a perfectly spiral finish very floriferous, and in every respect a splendid rose, highly tea perfumed.

Irs. Leonard Petrie. (H. T.) Honey yellow with delicate claret smear on back of outer petals, passing to pale sulphur-yellow in the developed blooms: flowers large, full, very smooth, with delightful fragrance.

Mrs. Walter Easlea. (H. T.) Glowing crimson- carmine, deepening to intense crimson-orange back of petals satiny-crimson; blooms large, full, imbricated form and very freely produced; petals massive, smooth and circular, deliciously perfumed, a fine forcing variety, good.

Mrs. Wilfred Lloyd. (H. T.) Lovely bright rose-pink, of great intensity as the bloom expands; flowers large, full and globular, perfect in form, a very highly perfumed variety.

Hybrid Teas of recent introduction, all of which are vigorous in growth, with the exception of My Maryland, which is robust.

Carola Konigin. Satiny rose, reverse of petals silverywhite; large, good form; floriferous.

Dorothy Page Roberts. Coppery-pink suffused apricot-yellow, petals very large. A very unique rose, possessing remarkably beautiful shades of color. Gold Medal, N. R. S.

Earl of Warwick. Soft salmon-pink, shaded vermilion; large, full, a fine decorative variety.

Elizabeth Barnes. Satiny salmon rose, with a fawn center, suffused with yellow, outside of petals, deep rosy red shaded with copper and yellow; large, full, perfectly formed, delightfully fragrant.

His Majesty. Deep vermilion, crimson toward the edges; full, large, sweetly perfumed. Awarded Gold Medal, N. R. S.

J. B. Clark. Deep scarlet, shaded blackish-crimson; large. Gold Medal, N. R. S.

Lady Alice Stanley, Deep coral-rose on outside of petals; inside pale flesh, slightly flushed deeper flesh; 
blooms large, full; fragrant, Gold Medal, N. R. S.

Lady Ashtown. Very large Rose du Barri, shading to yellow at base of petals; large, full, and pointed: excellent for any purpose.

La Tusca. Silvery-pink with deeper center'; large, full, fioriferous; a first-rate garden rose.

Lady Ursula. Flesh pink, large full, great substance, good form, petals large, smooth, circular, deliciously tea scented. Fine for all purposes.

Laurent Carle. Brilliant velvety carmine; very large, aluable either for exhibition or decoration.

Madame Melanie soupert. Yellow suffused carmine, lalge, full, fine.
My Maryland. Bright salmon-pink, with paler edges; delightfully fragrant; very floriferous.

Miss Alice de Rothschild. (Tea.) Rich deep citronvellow, wich intensifies as the bloom expands. Flowers are full, and of perfect form, with high pointed centers the petals charmingly reflexed. Deliciously fragrant.

Mrs. John Bateman. Deep China rose-color, with yellow at base of petals; blooms are perfect formation, very full with highly pointed center.

Otto Von IBismark. Growth vigorous, of free-branching habit, flowering freely and continuously; color somewhat like la France; grand for massing.

Prince de Bulgarie. Deep rosy flesll, shaded with salmon; large, full; good.

\section{Select List of Everblooming Roses}

In addition to the list of New Roses, we offer the following varieties, the very cream of constant blocmers. They should not be confounded with the so-called monthly Teas, sent out as pot-plants by some firms. They are hardy with a little protection if planted in spring, in order that they may become established during the summer. Being large plants they will bloom freely from June to November, and are worth many times mailing sizes, sent out by some growers. As they have all been thoroughly tested for hardiness, freedom of bloom and rigorous growth, one tries no experiment in planting these beautiful Everblooming Roses. They are all Hybid Teas with the exception of a few, which are designated; and, all things considered, are most valuable for bedding out and summer-flowering. They are a cross between the Hybrid Perpetuals and the delicate Teas. They have the hardiness of the former and the charming form and fragrance of the latter. This is the class to wich La France belongs.

Nice Gralname. Irory-white, tinted salmon. In this Ne have an absolutely distinct and magnificent Rose of the highest excellence. It is a strong, vigorous srower, of free and erect branching character, with massive, dark green foliage. Growth very smooth, with the appearance of being highly varnished. Every shoot is crowned with a bud, which develops into a flower of large size, enormous substance and perfect forll. This variety frequently varies both in form and colol. A marvelously free and continuous blooming color:
Rose.

Intoine Rivoire. Rosy flesh, shaded and edged with carmine; base of petals yellow, large, full and $1 \mathrm{mbri-}$ caterl; superb. Doctor Huey, the noted rosarian of Philadelphia, says of this Rose: "I quite agree with you about Antoine Rivoire. Have a dozen plants doing finely. I place it as the third best Hybrid Tea."

Isalduin (Helen Gould.) Beautiful pure carmine: large, full and fragrant; a most continuous flowering

IBardon Job. Tea. Flowers large, saucer-shaped, rich crimson, shaded with black, semi-double and very heautiful; foliage large and leathery. Plant exceeding1y. vigorous and productive.

Belle Siebrecht. Bright rosy pink; large, double and beautifully formed; very sweet and exceedingly floriferous. One of the best.

Betty. Color ruddy gold (a coppery rose overspread with golden yellow). Its blooms are extremely large, fairly full and of a glorious form; petals of ten 4 inches long. and is never out of bloom from June until cut off by frost. Its growth is extremely vigorous, erect and f a very free-branching habit.

Bessie Brown. A Rose of transcendent beauty totally distinct. The blooms are perfectly formed, of immense

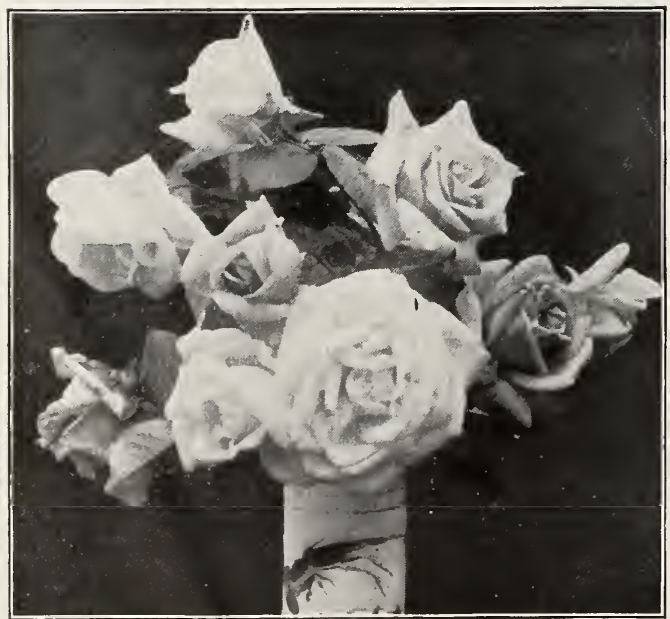

IIybrid Tea Roses size and substance; petals very smooth and shellshaped; creamy white; very highly perfumed. One of the finest Roses ever raised.

Captain Christy. Delicate flesh-color, deeper in the center; large. Effective; one of the best.

Caroline Testout. A beautiful rosy salmon; exquisite form, very sweet; vigorous grower, free and constant bloomer.

Clothilde Soupert. Polyantha. Flowers medium size, very double and beautiful. varying from light to pink No better light Rose for bedding, whether we consider its profusion of bloom the entire season or its vigorous growth.

Corallina. Tea. Flowers deep rosy crimson; pretty in bud and highly perfumed; an autumnal bloomer.

Countess of Gosford. Salmon, pink-rose and pink intermingled; base of petals suffused saffron-yellow. and the whole bloom shaded salmon. Color never and the whole bloom shaded salmon. Color never fades. The blooms are of perfect form, large, full,
very long and pointed; petals large and of great substance; very floriferous.

Dean Hole. Silvery carmine, shaded salmon; absoutely distinct and by far the finest in its way of color. The growth is vigorous, branching and very floriferous; flowers large, of great substance and fine form. A variety of great excellence and useful for any purpose. Gold Medal, National Rose Society.

Etoile de France. Color velvety crimson, center vivid cerise-red; blooms very large, full and magnificent cupped form; very beautiful. Vigorous in growth fragrant and lasting.

General McArthur. Bright crimson; large, full, free flowering; highly perfumed; very fine.

Gladys Harkness. Deep salmon-pink, of good shape; large and fragrant; vigorous, floriferous.

Grace Darling. Creamy white, tinted and shaded with peach; distinct flowers, large and full. One of the best.

Gruss an Teplitz. Brilliant cinnabar-scarlet shaded with velvety fiery red; a very effective decorative Rose. It is very fragrant, a free, strong grower, and the most profuse bloomer of all bedding Roses. The foliage is extremely beautiful, all the young growth being a bronzy plum-color.

Gustave Regis. Canary-yellow, with orange center beautiful in bud.

Gustave Nabbonnand. Tea. Delicate rose, shaded with yellow, fragrant and free-flowering; extra.

Harry Kirk. Tea. Absolutely unique. A splendid Rose, of most robust growth, with free-branching habit, flowering freely and continuously. The blooms are large, full, with large, smooth petals of great substance; the form is perfect; the buds are long and elerant: color deep sulphur-yellow passing to a lighter shant: color deep sulphur-yellow, pasing Awarded Gold Medal. N. R. S. Dict or Huey, of Philadelphia. writes: "Harry Kirk is a great and glorious Rose. had five different periods of bloom last summer. I had several blooms that opened $4 \frac{1}{2}$ inches in diameter. As the inner row of petals is incurved, even when fully opened, it does not present a flat appearance. Petals are of great substance, and the flower is quite fragrant." 
Kaiserin Augusta Victoria. Pure white, with yellow center; outer petals reflexed; its fragrance is unique; its foliage vigorous and glossy:

Iillarney. A charming Rose of robust growth and free-branching habit; blooms large, buds long and pointed; petals very large and of great substance; flesh shaded white, suffused pale pink; a lovely and distinct Rose of great merit.

Lady Battersea. Beautiful cherry-crimson, permeated with an orange shade; the flowers are of moderate size and almost full; very free-flowering.

Lady Clanmorris. Creamy white, with delicate salmon center, edge of petals margined pink; sweetly perfumed: vigorous and free-flowering. A fine variety.

I France, Beautiful pale peach, rose center; very large and full; free bloomer. An old favorite, without which no collection is complete.

Lyon. Shrimp-pink, at ends of petals, center coralred or salmon, shaded with chrome-yellow, making a most distinct and charming combination. The flowers meres or great substance, broad, and very smooth; very fragrant.

Madame Jules Grolez. Fine, satiny china-rose color rery bright and attractive; large full and of good form and very free-blooming. A distinct and excellen new Rose. Regarded as one of the best new Roses in Europe.

Madame Jos Combet. Creamy white; large, full, fine form. A grand Rose; rather late-blooming.

Madame Abel Chatenay. Rosy carmine, shaded with pale vermillion-rose, and tinged with salmon; very distinct and attractive.

Iadame Cadeau-Ramey. Rosy flesh, shaded with yellow at base of petals; large, full, and of perfect form. One of the best newer Roses.

Madame Ravary. Hardy and very floriferous; color beautiful orange-yellow; flowers very large. The best yellow Rose.

Iaman Cochet. Tea. Flowers large, full and double; color clear carmine-rose; exquisite in bud. Bloom. in great profusion; very fragrant. Almost as hardy as the Hybrid Teas.

Mildred Grant. Silvery white, edge of petals shaded and bordered with pink; blooms are of enormous size and great substance, with high-pointed center, and last long in good condition. The petals, which are of unusual length, are perfectly shell-shaped and very massive; the growth is robust, vigorous and absolutely distinct, every shoot being crowned by a flower-bud, which is carried on a perfectly erect and very stout flower-stem; the wooc and foliage which is light glossy green, is most striking and attractive. Altogether this is the orandest variety ever raised and may be termed the Rose of the century. Received a Gold Medal from the National Rose Society of England. See illustration.

Mrs. Peter Blair. A decorative Rose of exceptional merit, though occasionally it will produce exhibition blooms. It is of robust habit, with large spines and lovely foliage. The flowers are lemon, with golden yellow center, produced continuously throughout the season. Deliciously perfumed.

Mrs. David Jardine. A glorious and most charming Rose, and one that is of immense importance to this section. It possesses vigorous and erect growth, together with marvelously free-flowering habit. The blooms, which are produced on every shoot, are of very large size and perfect form, beautiful in its several stages of development. The color is a delightful shade of bright rosy pink, shading in the outer petals to salmon-pink. quite distinct from any existing variety. In this Rose we have produced a flower possessing all the chasteness and floriferousness of a Tea combined with the erect and vigorous growth of a Hybrid Perpetual. It

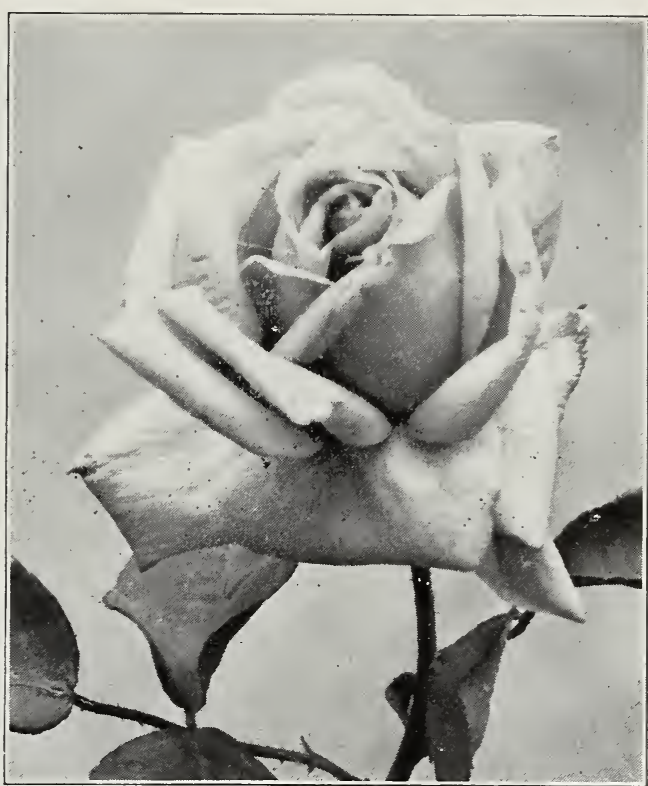

Mildred Grant

will eventually supersede the Catherine Mermet type. It has been inspected growing and flowering by the Committee of the New York Florists' Club, who gave their diploma of superiority, awarding it the highest number of points ever given to a new Rose since the formation of the Society.

Perle d'Or. Polyantha. Nankeen-yellow, with orange center; small, but full; very beautiful and always in bloom

Souv. de la Malmaison. Bourbon. This is the best of all Bourbon Roses. One of the best flesh-white Roses in cultivation; especial favorite because of its large, sweet Roses continuing in bloom until late in the season.

Souvenir de Pierre Notting. Tea. Apricot-yellow, blended with coppery yellow; bud long, opening into a large, full and finely formed flower; a very distinct and beautiful variety.

Souv. du President Carnot. Rosy flesh, shaded with white; fine long buds on stiff and long stems; delightfully fragrant. One of the best ever-blooming Roses ever introduced.

Viscountess Folkestone. Creamy pink, center salmonpink; large and sweet. Extra variety.

White Maman Cochet. Tea. Habit strong and upright like its parent, Maman Cochet having all the fine qualities of that grand Rose. Flowers are of enormous size, remarkably round and full; clear snowy white throughout and very fragrant.

Wm. Shean. A glorious Rose of unquestionable merit, having immense size, perfect form and substance. Color the purest pink. One of the largest Roses yet distributed.

\section{Hardy Hybrid Perpetual Roses.}

The following list, selected for hardiness, freedom of bloom, vigorous growth, fragrance and form, includes only first-class sorts-the cream of remontants. The plants are select, extra size two-year-old; grown on land especially adapted for Roses. In planting, the bud or joint should be planted 2 or 3 inches below the surface, which, to a great extent, prevents wild shoots. If one does appear, it is readily recognized by its seven leaflets, and is easily removed. About fifteen varieties may be had on own roots if desired. Formerly we offered Holland-grown stock at $\$ 15$ per 100 , but about 99 in 100 of our customers prefer to pay a little more for the Holland-grown stock at $\$ 15$ per 100 , but about 99 in 100 of our customer
best. We therefore offer no Holland stock. For prices see order sheet.

Alfred Colomb. Bright carmine-red; large and full; fine globular form.

Anna de Diesbach. A beautiful carmine of perfect form and very sweet.

Baron de Bonstetten. Rich, velvety maroon; large and full; very fine.

Baroness Rothschild. Light pink, suffused with white; large, globular form; extra fine.

Ben Cant. Flowers large and finely formed; deep clear crimson, darker in the oenter; sweet-scented, thoroughly perpetual; very promising. "It is undoubtedly one of the finest Hybrid Perpetuals of its color ever raised."-The Garden, London.

Clio. Flesh-color, shaded in the center with rosy pink; flowers large and globular; handsome foliage.

Fisher Holmes. Shaded crimson-scarlet; very brilliant; large and full.

Francois Michelon, Deep carmine-rose, reverse of petals silvery; fragrant and free bloomer; excellent 
late in June and July, when other varieties are gone and also in the autumn.

Frau Karl Druschki. We cannot speak too highly of his grand Rose. It is perfectly hardy, vigorous, and a free and continuous bloomer. No Rose has attracted greater attention of late years than has this one. It is the purity of whiteness. We sold more plants of this Rose last season than of any other variety, Mildred Grant holding it a close second. Blooms very large, perfectly formed; snow-white, with shell-shaped petals, opening well; strong and vigorous; an ideal white Rose. Has won many prizes since its introduction in 1900 .

General Jaqueminot. Brilliant red; velvety, large and double; fine for massing.

Grand Mogul. Deep crimson, shaded with scarlet and black.

Earl of Dufferin. Rich velvety crimson, shaded with maroon; large, full and deliciously fragrant.

Jean Liabaud. Velvety crimson-maroon; large, full and fragrant.

Iugh Dickson. ( $H$. P.) Brilliant crimson, shaded scarlet; good size and fine form; petals smooth, slightly cupped and reflexed Free-flowering and vigorous in growth; very highly perfumed. Gold Medal.

John Hopper. Bright rose, with carmine center; a profuse bloomer and standard sort.

La Rosiere. Maroon-crimson, shaded with black; cupped, double and effective.

Mabel Morrison. A sport from Baroness Rothschild, which it resembles in many respects. Color is white, sometimes tinged with pink. In autumn flowers are pale pink.

Madam Gabriel Luizet. A delicate and beautiful pink large and full; cupped and very sweet. Equal to the Baroness Rothschild as an exhibition Rose.

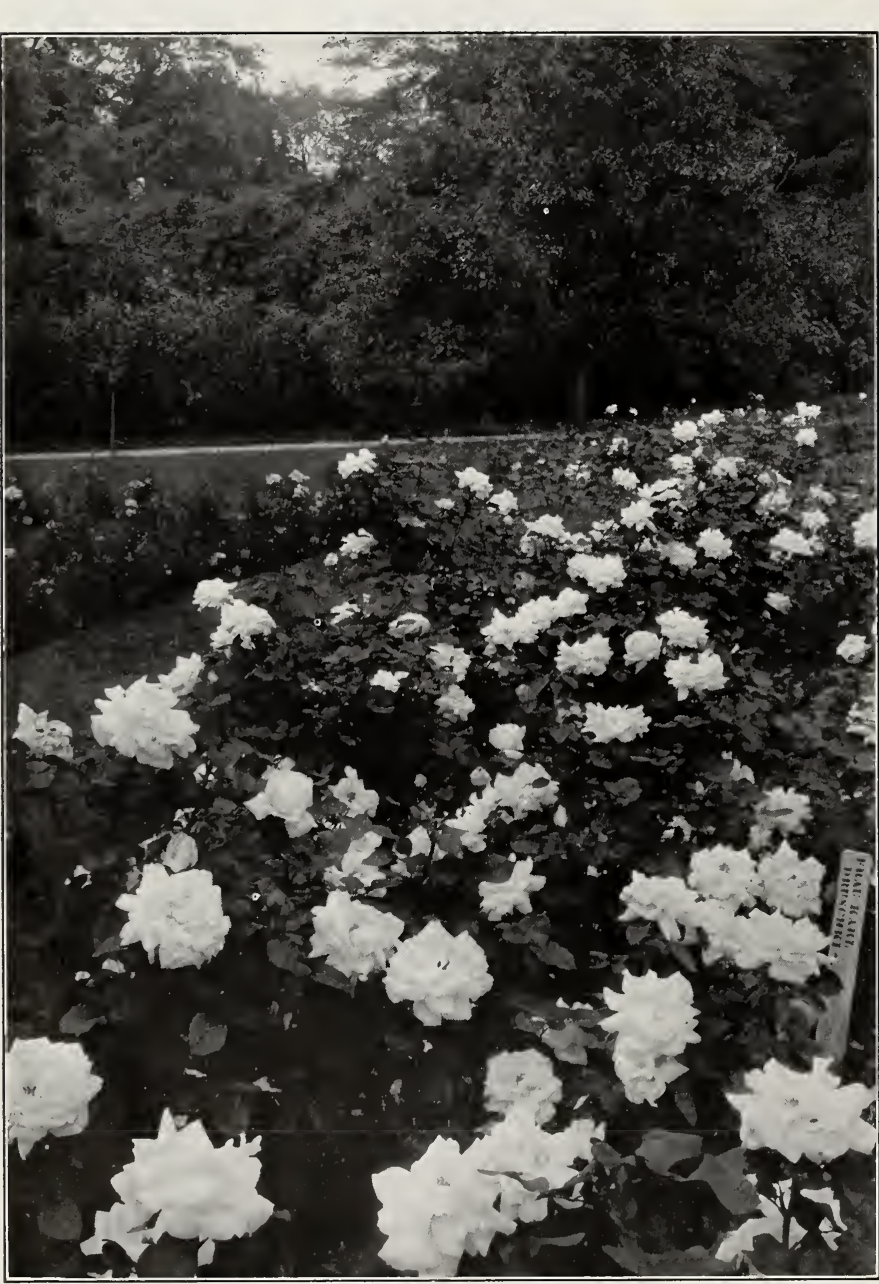

Frau Karl Druschki
Iadam Victor Verdier. Rich bright cherry-color large, full, fine cupped form; superb; a most effective

Magna Charta. Bright pink suffused with carmine very large, full and of good form; habit erect; foliage ich; very abundant in bloom.

Marchioness of Londonderry. Ivory-white; large, shell-shaped petals of great substance; highly perfumed; growth vigorous and foliage very handsome. Awarded a Gold Medal by the National Rose Society of England.

Margaret Dickson. Is white, with pale flesh center large shell-like petals of good substance; form good; foliage handsome, dark green; fragrant.

Marcuerite de St. Amande. Bright rose, very beautiful in the bud state. This variety will give more fine blooms in the autumn than almost any other in the class.

Marie Baumann. Brilliant carmine-crimson; large, full, of exquisite color and form; fragrant; extra fine

Marshall P. Wilder. Cherry-red; large, well formed and very fragrant. Very free bloomer late in autumn.

Maurice Bernardin. Vermilion; large, full and of fine form. Blooms in clusters; very prolific.

Merveille de Lyon. Pure white, sometimes washed with satin-rose; very large, full and cupped; similar to parent, Baroness Rothschild, but larger.

Mrs. George Dickson. (H. P.) Delicate soft pink: continuous bloomer.

Mrs. R. G. Sharman-Crawford. Deep rosy-pink, outer petals shaded blush; large and of good imbricated form; one of the most constant flowering from early summer until late in autumn. Received a gold meda from the National Rose Society of England. One of the

Mrs. Harkness. A blush sport from Heinrich Schulteis.

Prince Camille de Rohan. Crimson maroon, rich and velvety: large and full; one of the best of the old Roses.

Mrs. John Laing. Soft pink, of beautiful form; very fragrant and freeflowering.

Paul Neyron. Deep rose color, very large, fine form and habit; the largest Rose; very desirable. One of the best.

Queen of Queens. Pink, with blush edges: large and full, of perfect form and a true perpetual-flowering Rose; distinct and equally good as a garden and exhibition Rose. One of 4.e finest of its color. Gold Medal National Rose Society.

Reynold's Hole. Maroon, shaded with crimson; large and of globular form; distinct and good.

Rodocanachi. Soft transparent rosepink good form, and fragrant; growth vigorous; a grand Rose.

Soleil d'Or. Hybrid Perpetual. The only yellow Hybrid Perpetual. A cross between Persian Yellow and Antoine Ducher; it has the perfect hardiness: of the former, with more full, globular flowers, varying in color from gold and orange to reddish gold, shaded with nasturtium-red. Strong two-year plants.

Tom Wood. Cherry-red; large, shell-shaped petals of great substance. Flowers freely and continuously from: early summer until late in the autumn.

Uldrich Irunner. Bright cerise-red. In all respects a very fine Rose

\section{Roses in Tree Form}

Roses in tree form are among the most showy of plants. Stock grown on Rngosa has proven so successful in our trying climate that we have this season prepared to furnish larger numbers than ever of tree Ramblers and other choice varieties. For prices. see order sheet.

Crimson Rambler in Tree Form. The accompanying photo-engraving of Tree Rambler gives but a faint idea of the mass of crimson bloom. We offer these plants in 2-, 3- and 4-year sizes on Rugosa.

Dorothy Perkins and Farquhar in Tres Form. Our customers have been so much pleased with Crimson Rambler in tree form that we have this: year prepared a fine stock of two oth- 
er climbing Roses as standards. These are on strong Rugosa stems and will produce a magnificent effect.

Standard Baby Rambler. The continuous bloom and perfect hardiness of this perfect hard Rose has made it very popular. We are pleasvery popular. We are pleassupply a limited number of plants on Rugosa.

\section{Other Standards}

We offer other varieties, among which are the following:

Alfred Colomb

Antoine Rivoire

Baroness Rothsehild

Clio

Caroline Testout

Etoile de France

Frau Karl Druschki

Gruss an Teplitz

General Jaqueminot

J. B. Clark

K. A. Victoria

Killarney

La France

Maman Cochet

Magna Charta

Mrs. R. G. Crawford

Mrs. John Laing

Marie Baumann

Ialmaison

Paul Neyron

Prince Camille de Rohan

Ulrich Brunner

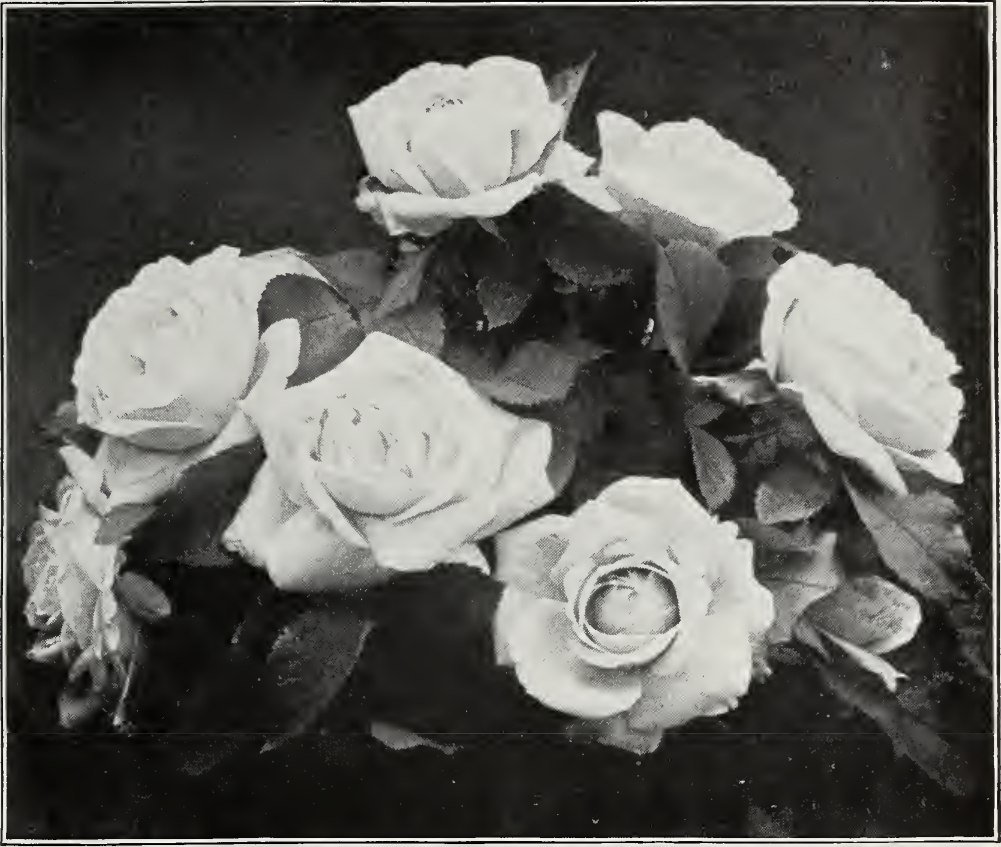

\section{Miscellaneous Roses}

Austrian Copper. Flowers single, brilliant, coppery red, outside of petals dull gold; a very effective Rose.

Cabbage Centifolia (Cabbage Rose). Rose-color; large size, globular form; very fragrant; superb variety.

Coquette des Alpes. White, slightly shaded with carmine; medium size; form semi-cupped; wood longjointed; larger flowers than the others. The strongest grower of its class.

Coquette des Blanches, Pure white, sometimes faintly tinged with pink. flowers of medium size, some what flat, but full and very pretty; growth more bushy
Mrs. R. G. Sharman-Crawford

and symmetrical than any of the others. One of the hardiest. Later than the rest to flower.

Harrison's Yellow. Fine golden yellow, semi-double; flowers profusely.

Iadame Plantier. Pure white; about medium size; full; produced in great abundance early in the season. One of the best white roses for hedges.

Mignonette. A splendid variety of Rose for edging beds; deliciously perfumed and constantly in bloom. Dwarf.

Iultiflora Japonica. Exceedingly free-flowering, fairly covering itself with great clusters of small white single, sweetly fragrant flowers. It grows rapidly, and is a valuable shrub.

Persian Yellow. Bright yellow, small, nearly full; like the above two, should be pruned little, as the flowers are produced from the terminal shoots of the old wood, or prune one bush one year and another the next.

Rosa spinosissima. Low shrub, with upright branches; 3 to 4 feet high. Foliage is small and dark; flowers single, pure white or pink; a very persistent bloomer during a large portion of the summer, followed by deep black heps or seed pods during the winter. Being exempt from insect pests and perfectly hardy, it should be freely planted. $75 \mathrm{c}$.

Rubiginosa. (Sweetbrier; Eglantine.) Dense shrub, attaining 6 feet. Flowers bright pink, $1 \frac{1}{2}$ to 2 inches in diameter; heps ovoid, orange-red or scarlet; a handsome hardy Rose of compact habit, whose foliage exhales a very agreeable, aromatic odor.

\section{Rugosa Roses and Their Hybrids}

A very interesting group from Japan. They are exceedingly hardy, and thrive in almost any soil or situation. They form strong bushes 3 to 4 feet high, furnished with handsome glossy foliage which renders them highly ornamental. They continue to bloom from June to November, after which the bright red seed-pods are striking objects during winter. They make striking objects during
grand shrub effects.

Atropurpurea. The flowers, produced in 


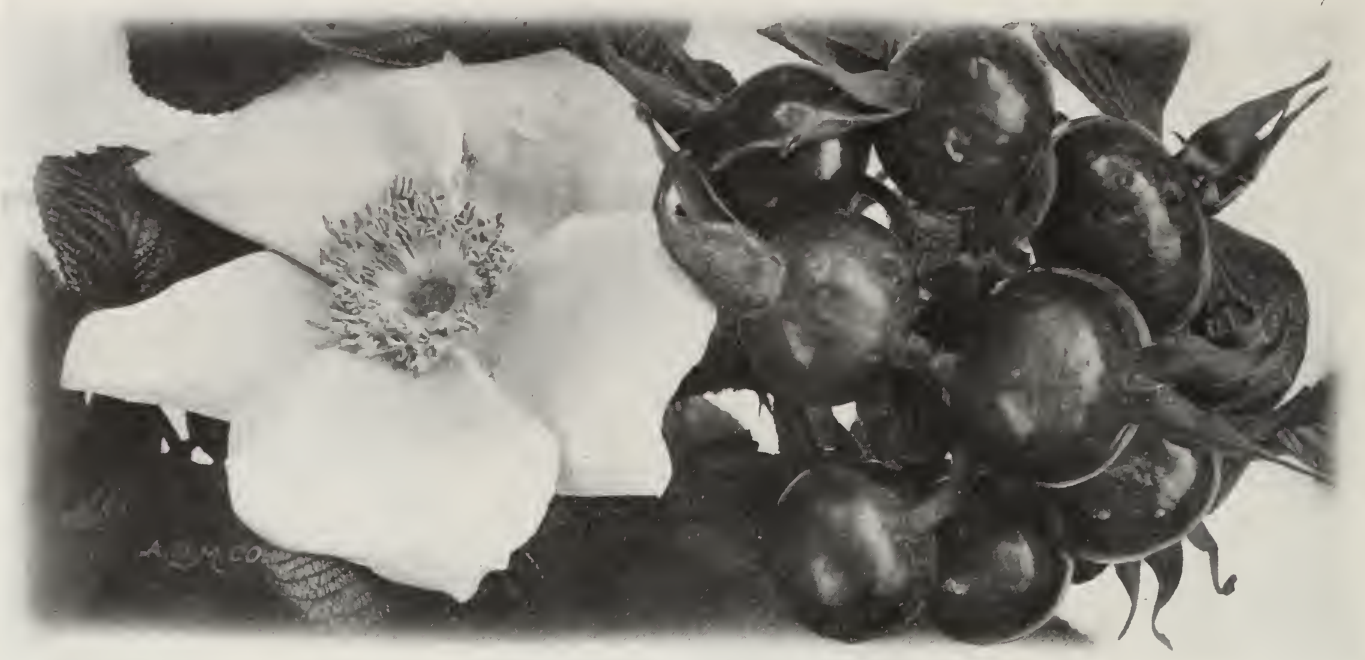

Rugosa Rose and Heps

large bunches, are crimson-maroon, and in the bud state almost blackish crimson.

Belle Poitivine. Rose-color, double, very floriferous and very sweet.

Blanc Double de Coubert. A double white form of Rugosa alba, large and showy; delightfully fragrant. Superb.

Conrad F. Meyer. Clear silvery rose; large fragrant flowers; bud well formed; foliage not like Rugosa.

Madame G. Bruant. Buds long and pointed, when open semi-double; pure white and fragrant.

Rugosa rubra. A most beautiful bright rosy crimson. Its flowers, borne in clusters nearly all summer, are delightfully fragrant.

Rugosa alba. Same as above, except that color is pure white,

\section{Moss Roses}

This is a favorite class on account of the beautiful buds, which, for bouquets and cut flowers, are invaluable. They require close pruning and high culture. The four kinds that follow are considered best sorts.

Crested Moss. Deep pink-colored buds, surrounded with a mossy fringe and crest; a fragrant and very beautiful Rose.

Gracilis. Deep pink, buds beautifully crested.

Salet. Light rose, large, full and beautiful in bud.

White Bath. The best white Moss Rose.

\section{¿Climbing and Trailing Roses}

American Pillar. (Polyantha.) Very vigorous, producing huge clusters, followed in autumn with red heps; flowers single and large, three to four inches across; lovely shade of pink, with a clear white eye and bright yellow staimins.

Ards Pillar. Rich velvety crimson, the perfection of an exhibition, garden and pillar Rose; the growth is very vigorous, with very large, most distinct and attractive foliage; the blooms are produced with great freedom. and are large, full and of cupped form; petals very large and smooth; one of the finest varieties sent out of late years.
Carmine Pillar. Flowers very large, single, bright rosy carmine; grows 10 to 12 feet in a season.

Climbing Kaiserin Augusta Victoria (Mrs. Robert Peary). A sport from the well known namesake, from which it has inherited the floriferous and other beautiful qualities, but hardy as a Moss Rose.

Climbing Folkestone. Hybrid Tea. Flesh color; same excellent qualities as the Viscountess Folkestone.

Climbing Caroline Testout. Caroline Testout has long held a very high rank among ever blooming Roses, and this climbing sport bids fair to be as popular. Extra-strong, two-year plants.

Crimson Rambler. It succeeds everywhere, is perfectly hardy and retains its foliage into the winter. Notwithstanding the fact that this Rose has been on the market several years, the demand is now greater than ever.

Dawson. This is a cross between the Japanese Rose, Multiflora compacta and General Jacqueminot. A wonderfully strong grower, with flowers of a bright carmine, very double and produced in large, pyramidal clusters.

Empress of China. Flowers of good size, soft red; blooms from June to November. A strong grower and free bloomer.

Flwwer of Fairfield. (Polyantha.) Very vigorous grower; color, brilliant crimson, base of petals white, flowering in profusion.

Helene. Individual flowers larger than those of Crimson Rambler; semi-double; color violet-rose, with yellowish white center. Habit fully as strong as the Rambler, but more graceful.

Leuchstern. A new polyantha, producing in great profusion large bunches of cineraria-like flowers; color bright rose with large white eye; growth and foliage distinct and beautiful; excellent for pyramids. Caused a great sensation at the Temple Flower Show in London.

Rubin. Deep crimson blooms larger and fuller than Crimson Rambler; beautifully formed; hardy and very vigorous.

Setigera. A very popular single flower; 3 inches in diameter; blooms just after Crimson Rambler. Very showy and effective.

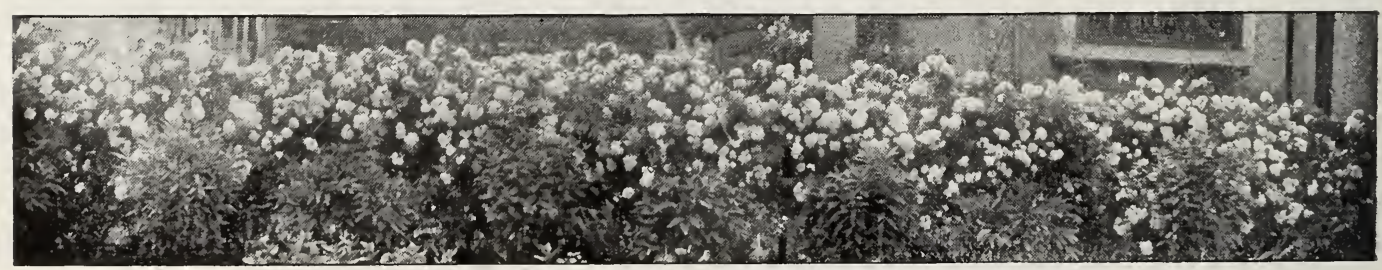

Lady Gay and Improved Dorothy Perkins. 
Tausendschon. (Polyantha). Pink, rosy carmine when expanded; large clusters.

Trier. Semi-double, producing large clusters of creamy white flowers in great abundance all summer. One of the best new climbing Roses.

Veilchenblau. (Polyantha.) Very vigorous, producing flowers of medium size, in large bunches; color, reddish lilac, changing to amethyst and steel blue.

Zepherine Drouhin. Bourbon. This is an old Rose which is very popular with those who have been for tunate in securing it. It is large, semi-double and of exquisite rose color; a very strong grower and may be used either as a pillar or bush Rose. Sweet and floriferous.

\section{Wichuraiana and its Hybrids}

This includes some of our most beautiful climbing Roses. The Hybrids crossed with this type, a rampant trailing Rose, and various strong, upright growers, produce vigorous growth and freedom of bloom combined with the beautiful Wichuraiana or evergreen foliage. The foliage is of a leathery texture, a beautifu age. The foliage is of a leathery texture, a beautiful shiny green, and not only is proof against all in

but is retained

Debutante. Beautiful soft pink, double fowers in and again in September and October.

Delight. Color, a bright carmine, base of the petals white, with the center filled with yellow stems. This harmonious color combination is intensified by the rich glossy foliage common to the Wichuraiana Hybrid.

Dorothy Perkins. We consider this the best pink climber, rivaling Crimson Rambler in all but color which is clear shell-pink and does not fade. It excels in beautiful foliage, size and fragrance of bloom.

Evergreen Gem. Flowers buff in bud, changing to almost white; 2 inches in diameter; perfectly double and with the scent of the Sweetbrier; foliage very dense and bronzy.

Farquhar. Undistinguishable from Dorothy Perkins. Gardenia. Flowers cream, 3 to $3 \frac{1}{2}$ inches in diameter; delightfully fragrant.

Lady Gay. Polyantha Seedling from Crimson Rambler; flowers of good size, delicate cherry-pink, fading to soft white; borne in very large clusters; a magnificent variety.

Pink Roamer. A strong grower with clsuters of rich pink flowers with almost white center; orange-red stamens.

Sweetheart. Bright pink in bud, on opening shades to a white; double flower, deliciously fragrant.

W. C. Egan. Flowers large, very full, silvery pink, in clusters.
Wichuraiana. (Memorial Rose). This is a distinct and valuable low trailing species from Japan. The pure white flowers are produced in profusion during the month of July.

\section{Roses for Green House Planting}

Besides the heavy two and three year old plants offered in the preceding pages, we would call the attention of those who annually plant young stock in greenhouses, to the following choice varieties which we offer at the prices named. These will be shipped direct from Cromwell, Conn., where we have found one of the best growers of greenhouse stock.

Greenhouse Stock from $2 \frac{1 / 4}{4}$ ch pots. Not for outdoor planting.

\begin{tabular}{|c|c|c|c|c|}
\hline Aaron Ward. & $\begin{array}{l}\text { Doz. } \\
\$ 4.00\end{array}$ & $\begin{array}{c}100 \\
\$ 20.00\end{array}$ & $\begin{array}{l}\text { Doz. } \\
\$ 2.50\end{array}$ & $\begin{array}{r}100 \\
\$ 10.00\end{array}$ \\
\hline Melody & & & 2.50 & 12.00 \\
\hline Hillingdon & 4.00 & 25.00 & 3.00 & 20.00 \\
\hline My Maryland & 2.00 & & & 10 \\
\hline Mrs. Taft (Antoine Rivoire) & 2.00 & & & 7.50 \\
\hline$\ldots \ldots \ldots \ldots \ldots$ & 2.00 & 1 & 1.50 & 7.50 \\
\hline Sunburst & 7. & & & \\
\hline Double White Killarney. & 7. & & 6.00 & 32.00 \\
\hline Double Pink Killarney... & 3. & & & \\
\hline Killarney Queen ... & 7. & 36 & 6.00 & 32.0 \\
\hline Harry Kirk & 2.0 & 15.00 & & \\
\hline $\begin{array}{l}\text { Golden Gate, Mrs. Ja } \\
\text { dine, K. A. Victoria, etc }\end{array}$ & & & & \\
\hline
\end{tabular}

We regret that our pages leave scarcely any room for letters of commendation of our stock. We have now been handling Dickson's Irish Roses for several years. These, with the climbing roses, grown to two, three and four years' sizes by us, have brought us many letters of commendation from buyers.

The fact that we filled an order for $\$ 1,200$ worth of roses for a well known rosarian who had bought of us for several seasons, is pretty good proof of the vigor of the plants we send out.

For the convenience of our customers we enclose an order sheet, giving the price of these roses, (which, by the way, are often much cheaper than those offered elsewhere for common stock).

C He is planning an addition to his rose garden and thought of sending to several firms for their best roses, but I told him he would do much better to send you the whole

I was talking over roses with Mr.— and we both came to the conclusion after trying roses from many of the prominent growers that yours were the best.

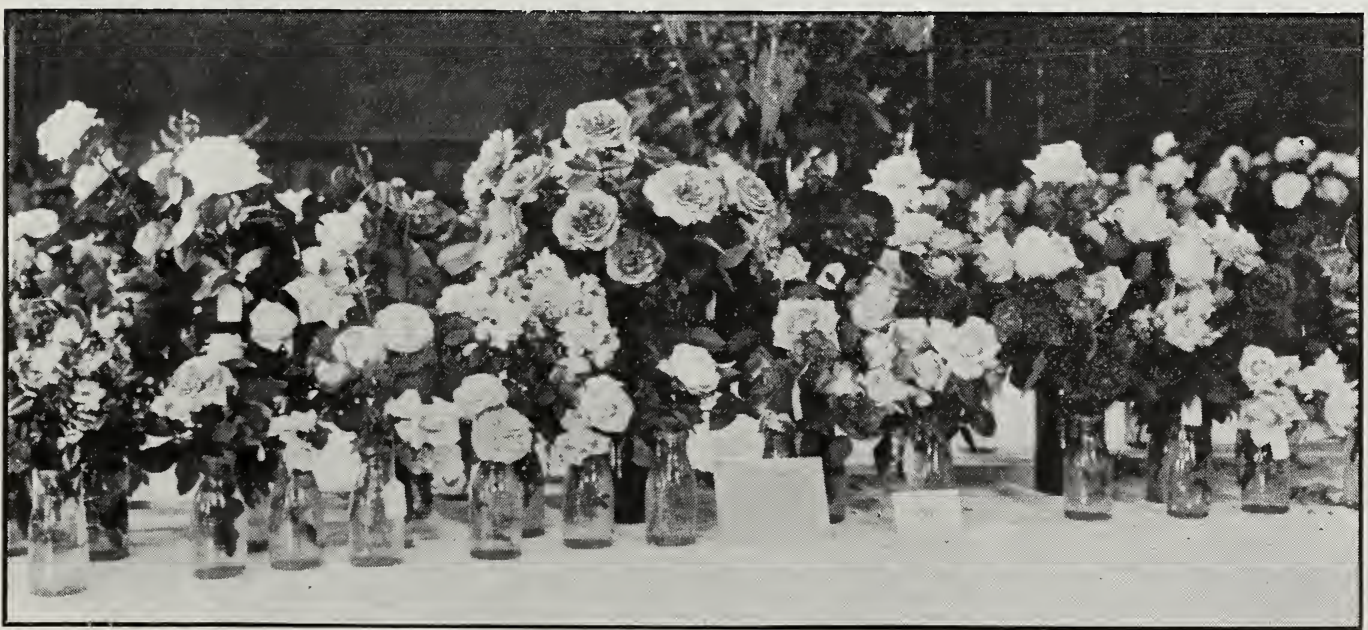

Group of Roses winning first prize by one of our cus tomers at Newport, $R$. I. 


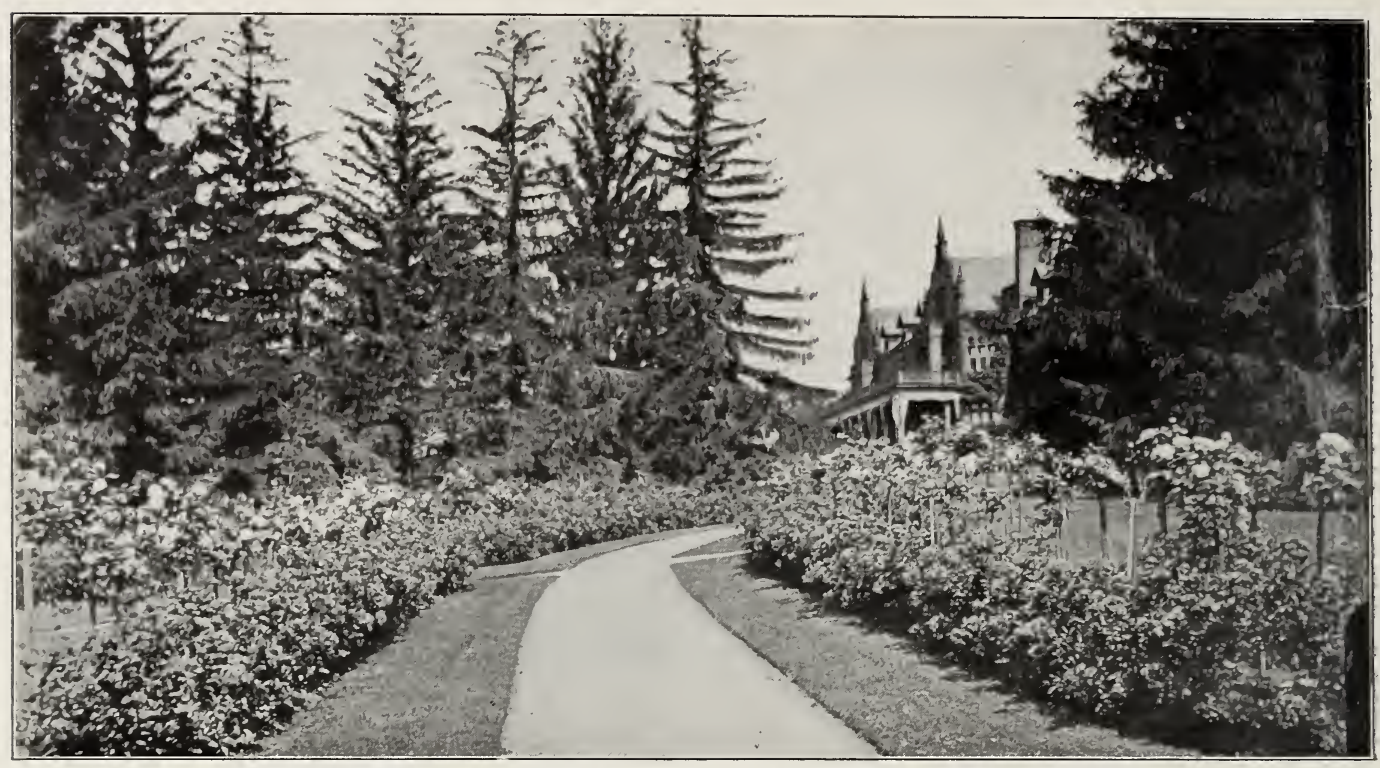

Path to Garden, showing Standard Roses back of those in bush form

\section{Time of Planting}

The sooner Rose plants are set in the spring the better, for no plant suffers more from being set out late than the Rose. We begin shipping about April 1, which is the proper time in this section and farther south. Northern shipments are made a little later, so that they will arrive as soon as the frost is out of the ground for planting. For the best results, the ground should be rich, friable and retentive of moisture, so that a constant and sturdy growth may be made throughout the season, for the more new growth the more Roses. In planting, care should be used not to bruise the roots, but after sufficient soil is on the roots to avoid this, the earth should be tamped very firm.

\section{Pruning, etc.}

All Rose plants should be severely pruned when planted and, in fact, every year pruning should be very thorough before the buds begin to swell, which, in this section, is the latter part of March. As a general rule, the more vigorous the variety the less it should be pruned. All dead, weak and unripe shoots should be cut out clean, the center of the plant thinned to admit air and light. For exhibition purposes, the well-ripened shoots may then be cut back to three or four eyes. It may be necessary to go over the plants again when the buds are formed to remove weak growth and buds that are not required.

As a preventive of insects attacks, dust hellebore (one part) and flour (two parts) on the foliage when leaves are fully expanded. This done in the morning, dew and flour forms a paste to hold poison on the leaves One application at the right time is usually sufficient to keep the foliage as clean as desired. If proper attention is paid to soil, planting and culture, one will be very little troubled with insects, as healthy plants are not so liable to attack and are strong enough to fight their own way.

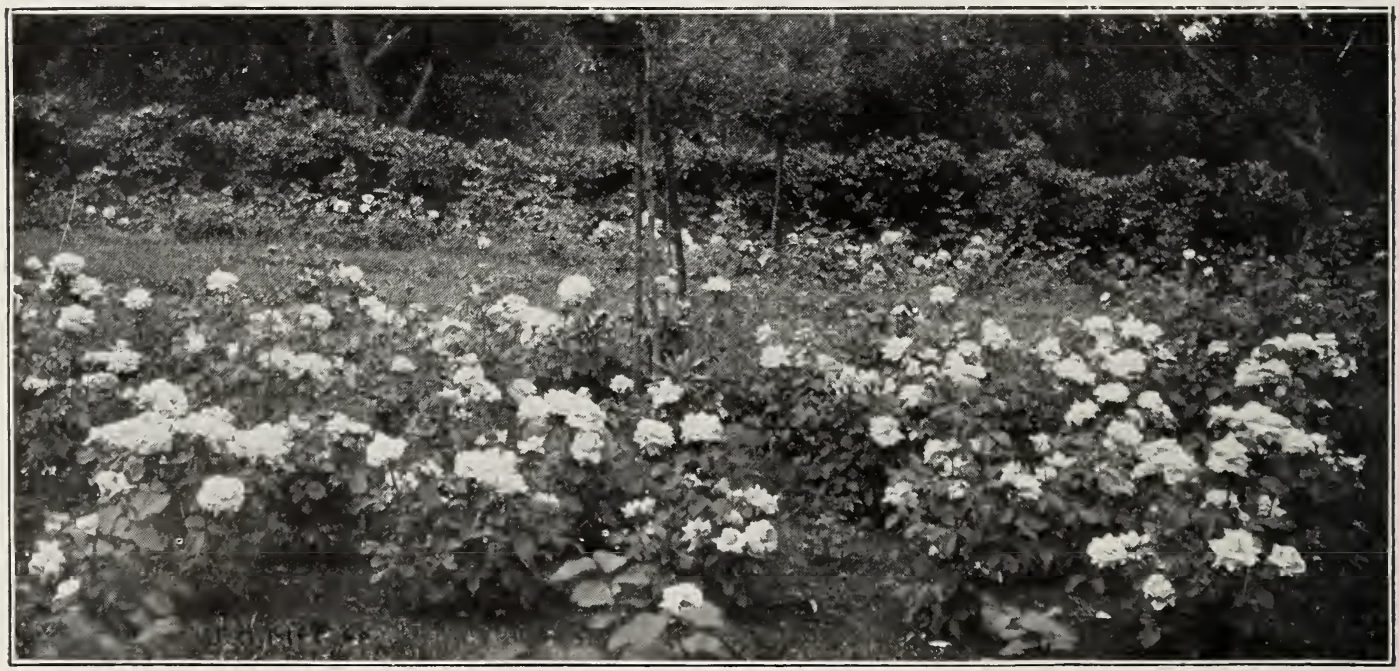

Bed of Crawford Roses in the Rose Garden at Greystone, Yonkers, N. Y. 


\section{Hardy Perennials}

Ordinary 15 cts. each, $\$ 1.50$ per dczen, except as noted. Extra Heavy, 25 cts. each, $\$ 2.50$ per dozen.

From the beginning the Rosedale Nurseries have made a leading specialty of Perennials. While we do not carry a large number of varieties, yet we grow a very select list of the best and liardiest. For example: We have not had the ambition to carry a large number of varieties of peonies, having eliminated many of the common while we do not call ourselves peony cranks or peony specialists we aim to carry a hundred of the finest kinds attainable. Why more? This would give us a dozen of the best white varieties, a dozen of the best flesh, a dozen of the best salmon, and so on through the different shades to the deepest crimson.

Design for proper arrangement of plants to give pleasing effects furnished at moderate cost. We have given attention to the matter of old-fashioned flowers a number of years, believing them far superior to the ordinary bedding plants. We have furnished many of the finest estates with plans and plants.

ANEMONES. Double and Single. Among the finest flowers for masses of bloom or for cutting. Some of the flowers are 4 inches across. They bloom in great profusion from September to November. 2 to 3 feet high.

Japonica. Carmine, with yellow center. Japonica alba. A fine large pure white.

Queen Charlotte. Large, semi-double flowers of La France rose pink, a color as rare among flowers as it is beautiful.

Whirlwind. A pure white semi-double variety.

ACHILLEA Ptarmica fl. pl., The Pearl. Milfoil. Dense masses of flowers from June to October, 2 feet high, of purest white.

AQUILEGIA. The Columbines are old favorites that succeed in any garden; they are beautiful in flower and foliage. The following are the best:

California Hybrids. A grand mixture.

Canadensis. Our native Columbine; bright red and yellow.

chrysantha, The beautiful golden-spurred variety.

caerulea. Rocky Mountain Columbine. Blue and white. One of the handsomest of the family.

Erskine Park Hybrid. This strain of Aquilegia originated at Lenox, Mass., by Mr. E. J. Norman, his result of hybridizing the finest of European and American varieties. Colors include blue, lavender, white, yelrieties. Colors include

Skinneri. Scarlet, with greenish tips; very distinct.

ASCLEPIAS tuberosa. Butterfly Weed. One of the showiest of our native perennials; about 2 feet high: blooms from July to September: close, compact heads and brilliant orange-colored flowers.

ASTILBE. Goat's Beard. Herbaceous Spirea. One of the most beautiful flowers in cultivation. They like partial shade; fine for cutting.

astilboides floribunda. White flowers; compact and graceful.

Japonica. The old favorite.

compacta multiflora. A variety much used for greenhouse growing.

Gladstone. Large white; new.

palmata elegans. A free-flowering silvery pink form.

BOLTONIA. False Chamomile. Among the showiest of our perennial plants, with large, single asterike flowers. The plant is in bloom during the summer and autumn months, and with its thousands of flowers open at one time, it produces a very fine effect.

asteroides. Pure white; very effective.

latisquama. Pink, slightly tinged with lavender.

CAMPANULA. (Bellflower.) Elegant genus; rich in color, profuse in bloom and of easy culture.

persicifolia. (Peach Bells.) Grows $1 \frac{1 / 2}{2}$ to 2 feet high and produces an abundance of blue, salvershaped flowers during June and July.

alba. A pure white form of the above.

gigantea Moerheimi. A giant new sort with large spikes of double fiowers 2 to $21 / 2$ inches in diameter. Blooms from the last of May to late in July.

pyramidalis. A most striking plant for tlie border, a perfect pyramid 4 to 5 feet covered with large blue flowers in September.

rotundifolia. (Blue Bells of Scotland.) This is the true Harebell or Bluebell famed in song and story, with beautiful clear blue flowers from June to with beautiful clear
August. 12 inches.

Medium. (Canterbury Bells. Cup and Saucer.) With out doubt this is the finest type of the old-fashioned, much-prized garden plant.

Medium roseum. Delicate rosy pink.

CHRYSANTHEMUM. (Mognpenny Daisy.)

maximum, Triumph. A strong-growing perennial about 2 feet in height, which continues in bloom from July until October; flowers daisy-like, 3 to 4 inches in diameter, with a golden center; of great substance lasting a week or more when cut.
hasta Daisy. Large, snowy white flowers 4 inches across; in bloom all summer and fall.

CHELONE. (Shell-Flower.) Stately, handsome perennials, growing 2 feet high; bears numerous spikes of large flower heads during the summer and fall.

Lycnii. Heads of deep red flowers; very fine.

CLEMATIS, SHRUBBY. This type of Clematis is deserving of the greatest popularity, and should be in every collection. They form bushes 2 to 3 feet high and during their long bloom are very attractive.

Davidiana. A most desirable variety, with fresh, bright green foliage and tubular, bell shaped flowers; very fragrant; erect habit. August and September.

COREOPSIS lanceolata grandiflora. One of the most popular hardy plants. The flowers are a rich golden yellow of graceful form and invaluable for cutting. The main crop comes during the latter part of June, but it continues in bloom, more or less, the entire summer and autumn.

DELPMINUM. (Hardy Larkspur.) What is more graceful in the flower bed than the delicate blue Larkspur? Bold, attractive, and perfectly hardy, it is of the easiest culture, and will establish itself in almost any garden soil. Plant early in the spring in deep soil in a sunny position. Cut out the old flower-spikes as soon as through fowering the old fiower-spikes as soon as through fowe

Belladonna. Probably the finest of this fine family; beautiful sky-blue flowers, always in bloom. 2 to 3 feet. $25 \mathrm{c}$ each; $\$ 2.00$ per doz.

Chinense. Grows about 18 inches high, and has large open panicles of handsome flowers in all shades of light blue to white.

elatum. Blue, with dark center.

Erskine Park Hybrids. These choice Hybrids were developed from a number of the best English varieties grown by E. J. Norman, of Erskine Park, Lenox, and are sure to please all who see them. They are the most vigorous in growth we have seen, and give a profusion of bloom unsurpassed by any. $20 \mathrm{c}$ each; $\$ 2.00$ per doz.

formosum. The old favorite dark blue variety; grows 3 to 4 feet high, and is in flower almost continuously from June to frost.

formosum coelestinum. A new variety of Formosum. of light color and an exquisite celestial bloom. 


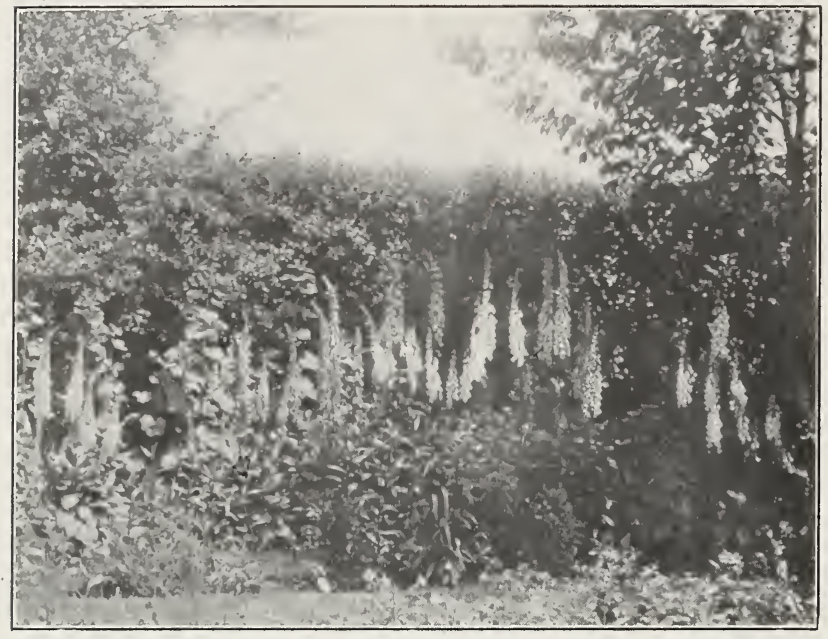

Digitalis (Foxglove)

IIANTHUS barbatus. (Sweet William.) Choice strain of mixed colors. We also offer a strain of dark crimson.

Dianthus deltoides. (Maiden pink.) A low-growing, creeping variety with pink and white flowers; fine for rockery.

arenarius. (Sand Pink.) A single-flowering variety of the common garden Pink; very sweet.

plumarius semperflorens. These are the old favorite hardy garden Pinks, bearing sweet, clove-scented flowers in May and June.

DICENTRA. (Bleeding Heart.) Combines a fern-like grace with the flowering qualities of a good hardy perennial.

DIGITALIS. (Foxglove.) These well known plants give a wealth of bloom in June and July; are very effective in shrubbery and other half-shady places. See cut on opposite page from a photograph in a celebrated Newport garden.

ambigua, or grandiflora. Showy flowers of pale yellow, veined brown. July and August.

gloxiniaeflora. Very ornamental; color of the flowers varying from pure white to deep pink. We offer these in white, purple, lilac, rose and mixed colors.

lanata. Corolla gray, lip creamy white.

DORONICUM excelsum. (Leopard's Bane.) No plant is more effective than this for early bloom. Orangeyellow flowers 3 to 4 inches in diameter, on stems 18 to 20 inches long. $20 \mathrm{c}$ each, $\$ 2.00$ per doz.

ERIANTHUS. See Grasses.

ERYNGIUM. (Sea Holly.) Handsome ornamental plants from 2 to 3 feet high; well suited for borders, woodland, wild gardens, etc. The flower heads, which are produced from July to September, are useful to cut for vases or to dry for winter ber, are use

amethystinum. The finely cut, spiny foliage and beautiful thistle of amethyst-blue make this a very ornamental plant.

EULALIA. See Grasses.

FORGET-ME-NOT See Myosotis.

FOXGLOVE. See Digitalis.

FUNKIA. (Plantain Lily.) The different species are free-flowering, with spikes of bell-shaped flowers, but the chief value is in the foliage.

caerulea. Blue flowers; broad green leaves.

subcordata grandiflora. Pure white, lily-shaped, large, fragrant flowers in clusters. This day lily is very attractive in bed or border.

undulata media picta. Green and white variegated foliage; purple flowers.

Thos. Hogg. Broad, glaucous foliage, white border.

GAILLARDIA grandiflora. (Blanket-Flower.) One of the most effective and showy hardy flowering plants; beginning to flower in June, they continue one mass the entire season; they will thrive in almost any soil, but respond freely to liberal treatment. One flower is often a combination of yellow, orange and deep crimson.

GRASSES, Hardy Onnamental. These make very attractive groups.
Arundo Donax. A massive variety, growing to a height of 12 feet.

Arundo variegata. A beautiful variegated torm of the above. Foliage creamy white and green; grows 6 to 8 feet.

Erianthus Ravennae. Grows 9 to 12 feet high frequently throwing up 30 to 50 flower-spikes. Closely resembles the pampas grass.

Eulalia gracillima univittata. Compact in habit; narrow foliage, bright in color, with a silver midrib.

Eulalia Japonica variegata. A very ornamental variety, striped green and white, and often yellow; flower-stalks 4 to 6 feet high.

Eulalia Japonica Zebrina. (Zebra Grass.) The long blades of this variety are marked with bright yellow bands across the leaf.

GYPSOPHILA. (Baby's Breath.) These beautiful flowers of easiest culture delight in open, rather dry places; they are especially desirable for rock-work; also good for covering urkempt places with a mass of delicate bloom.

paniculata. A very elegant light and graceful perennial; when in bloom during August and September it forms a symmetrical mass 2 to 3 feet in height, of minute pure white flowers, forming a beautiful gauze-like appearance. flowers, forming a be

repens. An excellent trailing plant for the rockery, with clouds of small, white flowers.

HEIANTHUS. (Hardy Sunflower.) Where large borders are planted, the perennial sunflowers are among the most effective hardy plants. They are admirably free-flowering, succeed in any soil and are fine for cutting.

multiflorus fl. pl. (Double, Hardy Sunflower.) Flowers in great profusion during July and August; one of the best.

multiflorus maximus. Gigantic single variety, growing 5 to 6 feet high, surmounted by single golden yellow flowers; August and September.

HELloPSIS Pitcheriana. (Orange Sunflower.) Growing 2 to 3 feet high, and a perpetual bloomer; deep golden yellow, about 2 inches in diameter. very graceful for cutting.

HEMEROCALLIS aurantiaca major. (Yellow Day Lily.) New. Japanese variety, with brilliant orangeyellow flowers. Not so hardy as the other sorts.

flava. Few plants can be grown with so little trouble in the border and give such a valuable return as this one. It is so fragrant that it is sometimes called the yellow tuberose. The beautiful light green foliage curving gracefully is suitable for banks. Heavy plants.

Florham. Large; yellow; sweet-scented flowers during June and July. One of the best.

Kwanso fl. pl. A very free-flowering variety, with double flowers of rich copper color; $4 \mathrm{ft}$.

Thunbergii. Lemon-yellow, flowering in July and August. 2 to 3 feet. Excellent for cutting.

HIBISCUS. (Rose Mallow.) A valuable border plant, having handsome bright leaves and large showy blossoms.

albus. (Crimson Eye.) Large, showy white flowers; crimson eye. 4 to 5 feet. Blooms in August.

Moscheutos. Purplish red to nearly white, with darker eye; 5 feet; July to September.

roseus. Large showy rose flowers. 4 to 5 feet.

HOLLYIOCK (Althaea Rosea). One of the noblest of hardy plants. It is well fitted to break up ugly lines of shrubs or walls by its tall, stately growth. Deep cultivation, much manure and frequent watering in dry weather will secure fine spikes.

Double. Flowers form rosettes of lovely shades of yellow, crimson, rose, pink, orange and white.

Allegheny Fringed. Semi-double, graceful and beautifully fringed at the edge of the petals; 5 to 6 inches in diameter.

old-fashioned Single. The old-time favorites in choice mixture.

Montreal, Oct. 31,1911

rrived $O$. K. today in perfect condition and $I$ must say that they are larger and healthier than I have bought elsewhere." 


\section{Japanese Iris - Kaempferi}

Flower 9 to 12 inches in diameter; will grow in almost any siol that does not become too diy in summer. Prefer a warm sunny location. Prices: 20c each, $\$ 2.00$ per doz.; $\$ 12.00$ per 100 . A superb mixture made fron these varieties, $\$ 9$ per 100 . Our river bottom land produces extra fine plants at low cost of production, hence these low prices.

This set of varieties was selected from a large number of the best Japanese introductions and is, without doubt, as fine as any collection offered.

Spring is the best time to plant Japanese Iris. They are very easy of culture and are unsurpassed in NO. wealth of bloom by few, if any, perennials.

1 Iso-no-nami-Silvery white veined violet.

15. Gekka-no-nami-Dense, pure white, yellowish blotches, petaloid stigmas; six petals.

65 Ho-ojo-Ruddy crimson, primrose blotches, with white halo; petaloid stigmas white tipped with white halo; petaloid stigmas white tipped with purple; six petals.

20 Kuma-Funjin-Purple, overlaid with navy-blue, two standards; petaloid stigmas purple and blue; large orange blotches; six petals.

94 Komochi-Guma-Violet, double; several blooming close together at one time; six petals.

53 Bandai-no-nami-Clear white, with large radiating yellow blotches; oreamy standards; six petals.

56 Kakujakuro-Blue with purple heavily feathered Kakujakuro-Blue with purple heavily feathered
white; yellow blotches; standards blue, edged white; petaloid stigmas white; tipped blue; large flowers.

59 Osho-kun-Intense tyrian blue; yellow blotches radiating into white; petaloid stigmas dark violet: six petals.

61 Blue Jay-Sky blue, reined white.

62 Misutmoshito-Three petals; white mottled with violet purple.

i1 Pyramid-Light violet blue, slightly veined white.

\%2 Uji-no-hotaru-Bright violet-purple, shaded blue.

91 Kanran-White, densely veined with rich violet.

Yomo-no-umi-The finest double white.

Koki-no-iro-Light violet with white veins.

23 Yedo-jiman-Rich royal purple.

26 Uchiu-Bright crimson-purple with few white veins. 35-Shi-shi-odori-Rich royal purple, changing to deep purple.

40 Kanarinishiki-Greyish white marbled with violetpurple.

47 Renjo-no-toma-Light lilac suffused with light violet.

69 Waku-hotei-White, veined with violet blue.

11 Hano-no-nishiki-Violet purple veined with white.

14. Shishi-ikari-White ground, veined with dark purple.

16 Kumoma-no-sora-Silvery white, suffused throughout with soft, light blue; the largest threepetaled variety in cultivation.

55 Shuchiukwa-Crimson purple with white veins and center.

if Vayaura-White, occasionally marked with light violet.

\section{German Iris}

Early Autumn (September) is the best time to plant German Iris.

Large stock, low prices.

Strong divisions named, 10 cts. each; per dozen, $\$ 1.00$; per $100, \$ 8.00$.

Strong divisions mixed, $10 \mathrm{cts}$. each; per dozen 60 cts.; per $100, \$ 4.00$

Heavy clumps, named, per dozen, $\$ 2.00$; per $100, \$ 15.00$. Heavy clumps, mixed, per dozen, $\$ 1.25$; per $100, \$ 10.00$.

Apollon. Golden yellow, striped with plum color.

Atropurpurea. Purple; one of the best.

Augustina. Deep yellow, marked with maroon, giving a coppery hue.

Aurea. Clear golden yellow; fine.

Bessie. Yellow and brown.

Bougere. Lilac and velvety purple; distinct.

Celeste. Delicate light lavender-blue.

Colestine. Delicate lavender-self.

Canary Bird. Lemon yellow.

Common Purple. Purple; one of the best.

Common Purple. Purple;

Deloismison. Lavender and purple.

Eugene Sue. Creamy white, with purple spots and stripes.

Falcata. Yellow, tinged with purple and purple stripes.

Flava. Pale yellow; fine.

Florentina. White, tinged with blue and yellow.

H. Cramer. Delicate pale blue.

Hector. Light bronze, stained with purple; fine.

Hector. Light bronze, stained with
Ignititia. White, suffused with purple.

Ignititia. White, suffused with purple.

Innocence. Lavender fringed with white.
Jacquesiano. Deep maroon velvet, tinged with bronze and crimson; a rare and remarkable color.

Juliette. White, heavily reined with purple.
Lady Stump. Lavender and dark blue.

La Tendre. Lavender.

L'Avenir. Lavender; a beautiful shade.

Lemon. White, spotted with purple and deep purple stripes; fine.

Liabaud. Yellow and maroon; fine.

Louis Van Houtte. White, edged with blue.

Iadame Chereau. White ground, fringed with blue.

Madame Chereau. White gro

Ochroleuca. Golden yellow.
Pancrea. Buff and purple;

Pancrea. Buff and purple; distinct; fine.

Reticulata superba. Center larender, outer purple; fine.

Sampson. Rich golden yellow; crimson-maroon, veined with white.

Sappho. Clear blue and indigo, beautifully shaded.

Silver King. Flowers silvery white; distinct and fine.

\section{Pallida Section}

25 ets. each, $\$ 2.50$ per dozen.

Albert Victor. Beautiful lavender and blue Garibaldi. Fine, rosy-pink.

Her Majesty. Lovely rose-pink, falls crimson.

Leonidas. Rosy-mauve.

Pallida Dalmatica. Very large, fine larender for cutting.

Queen of May. Lilac, almost pink; very beautiful

Rutherford. Shade a little lighter than Dalmatica.

\section{New Hardy Alpine Iris}

These are perfectly hardy and useful for border for forcing. They bloom before German Iris. 20c each; $\$ 2.00$ per dozen.

Charmer. Light cream-color.

Hayden. White, suffused with light blue.

Josephine. Pure white.

Meteor. Rich reddish purple, with yellow beard.

Milton. Rich yellow, lined maroon; orange beard.

Stewart. Pure yellow.

\section{Various Irises.}

$\$ 1.00$ per dozen, $\$ 6.00$ per 109 .

Pseudacorus. (Common Water Flag.) Whoever has in his garden a pond, ditch or even a thoroughly damp spot ought to plant this Flag; 2 to 3 feet. Yellow.

Sibirica. (Siberian Flag.) 2 to 3 feet high, with narrow, grassy leaves; showy blue flowers, beautifully reined with white and riolet.

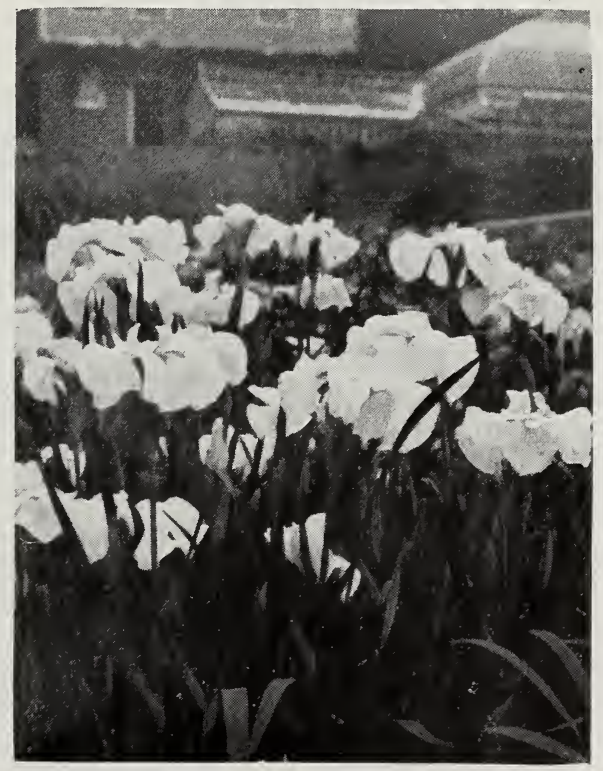

Japanese Iris 
LIATRIS. Showy plants, with long spikes of purple and pink flowers.

pycnostachya. (Kansas Gay-feather.) This most attractive plant blooms in midsummer; 3 to 4 feet high; rich purple flowers which last for a long time. spicata. Large purple spikes; very compact.

spicata. Noba. Clear lilac; 1 foot. July and August. LOBELIA cardiualis. (Cardinal-flower.) Grown in an ordinary border this plant has a stunted appearance, but in a good soil, well supplied with moisture, the effect is grand; the most vivid scarlet flowers are borne in great profusion and last a long time; August to September.

LYCHNIS alpina. (Campion; Lamp-flower.) A diminutive form of $\mathrm{L}$. Viscaria, the tufts seldom being more than a few inches high; grown without difficulty in the rock-garden or in rather moist, sandy soil: May and June.

Chalcedonica. A very desirable plant, bearing brilliant, orange-scarlet flowers; 2 to 3 feet high : liant, orange-scarlet
blooms all summer.

viscaria splendens fl. pl. (German Catchfly.) Forms a dense tuft of evergreen foliage surmounted by double, deep red, fragrant flowers, remaining in perfection for six weeks, during May and June.

MONAIRD. (Bee Balm.) Showy flowers of the simplest culture, thriving everywhere. Excellent for naturalizing in woods and shrubberies.

didyma. (Oswego Tea.) Robust; about 3 feet high: flowers bright scarlet, continuing in bloom a long time in summer.

MYOSOTIS. Beautiful alpine plants charming in all ways for rock-gardens.

alpestris. A compact plant, forming a cushion of the loveliest blue flowers, thriving in moist, gritty soil. palustris. A variety that is hardly ever out of flower: useful for a shady spot in the border; should be grown in partial shade or as a carpet to taller subjects, in moist, well-drained soil.

\section{Phlox}

Following the Iris and Peonies in time of bloom, but in no way behind them in popularity, are the Hardy Perennial Phloxes. We have finally succeeded in getting up a good stock of some of the varieties which are always short at planting time. We have weeded out all the magentas and purples and believe that our list is as select as that offered by any firm. As the first blooms are fading cut off flower spike and second blooming season will nearly equal the first.

Blooming size, $1 j$ cts, each; $\$ 1.50$ per dozen; $\$ 10.00$ per 100 .

Large clumps, $\mathrm{XX} 20$ cts. each: $\$ 2.00$ per dozen; $\$ 15.00$ per 100 .

Six at dozen rate, 50 at 100 rate, provided not less than three of a kind are ordered.

Amazon. Large flowers, pure white.

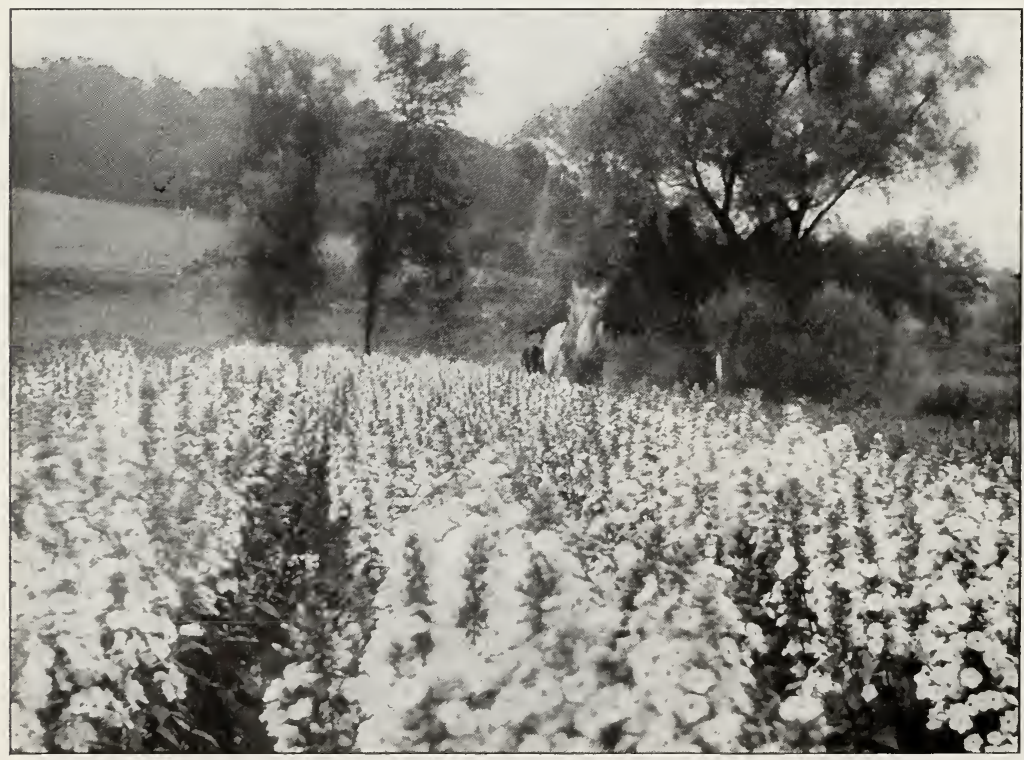

Phlox, Miss Lingard, in our Nursery

Pearl. Pure white.
Belvidere. Salmon-pink. A choice sort.

Bridesmaid. White, with large crimson center.

Beranger. White, suffused with pink; rosy lilac eye.

Caran d'Ache. Bright carmine-rose; distinct.

Coquelicot. Fine, rich scarlet with deep carmine eye.

Cross of Honor. Each petal lilac-color, with a white margin; beautiful

Eiffel Tower. Large flower; chaste, pure salmon with purple eye.

Henry Murger. White, with carmine eye. The best

La Vague. Large; rosy pink, with red eye.

Lothair. Large; rosy salmon, with crimson eye.

Matador. Large flower; bright orange-red. Distinct and fine.

I'rofessor Schlieman. Salmon-rose, with carmine eye

lantheon. Deep salmon-rose; very fine.

Peachblow. Delicate pink, with white markings.

Purity. Snow-white.

Queen. Pure white. Soft salmon-scarlet, white center.

R. P. Struthers. Bright rosy-red; crimson eye.

Sunshine. Deep salmon-pink; dark eye.

Wm. Goethe. Tyrian-rose; suffused with carmine-lake.

Miss I.ingard. We offer a fine stock of this new, everblooming variety. This Phlox blooms in May, fully six weeks earlier than the other sorts, and continues in bloom three months; a grand white variety, which should be in every collection; is not so tall a grower as Queen.

Phlox subulata. (Moss Pink.) Rose-pink.

PHysostegiA. (False Dragon-Head.) Handsome perennials, forming dense bushes 3 to 4 feet high, bearing long spikes of delicate tubular flowers.

Virginica. Soft pink.

PLATYCODON. (The Balloon Flower.) Closely allied to the Campanulas, bearing a succession of flowers from June until October.

grandiflorum. Deep blue cupped, star-shaped flowers; $1 \frac{1 / 2}{}$ to 2 feet.

grandiflorum album. A white-flowered form of the above.

Mariesa. Deep blue, bell-shaped flowers, nearly 3 inches across, on plants 1 foot high.

PRIMULA veris superba. Giant form of the English Cowslip, producing individual flowers from 1 to 2 inches across. Color canary-yellow, with golden center.

RUDBECKIA. (Cone-Flower.) This is the genus to which the Golden Glow belongs-a plant that has been very popular. Much better is the species Newmanii, with flowers of a rich orange-yellow, with velvety maroon center. They are from 3 to 4 inches in diameter and borne in dense masses from July to late October. The plant is more compact that Golden Glow, growing only 2 to $2 \frac{1 / 2}{\text { feet }}$ high.

S E D U M . (Stonecrop.) Rock and alpine plants, which thrive in nearly every soil. They are beautiful in the border and of the easiest cultivation. S. acre, from its creeping foliage called Golden Moss, has bright yellow flowers S. maximum atropurpureum grows from 1 to feet high, and from the vivid purple stems and vivid purple stems and mass. S. spectabile is distinct and beautiful. in dense, broad corymbs appear in August and last two months. The glaucous foliage forms a pleasing contrast to any highly colored foliage that may stand near it.

STOKESIA, cyanea. This is one of the best blue flowers, blooming from early July to late October. Flowers handsome lavender-blue, 3 to 4 inches in diameter; effective in masses or beds; it grows almost 20 inches high and is of easiest culture. 


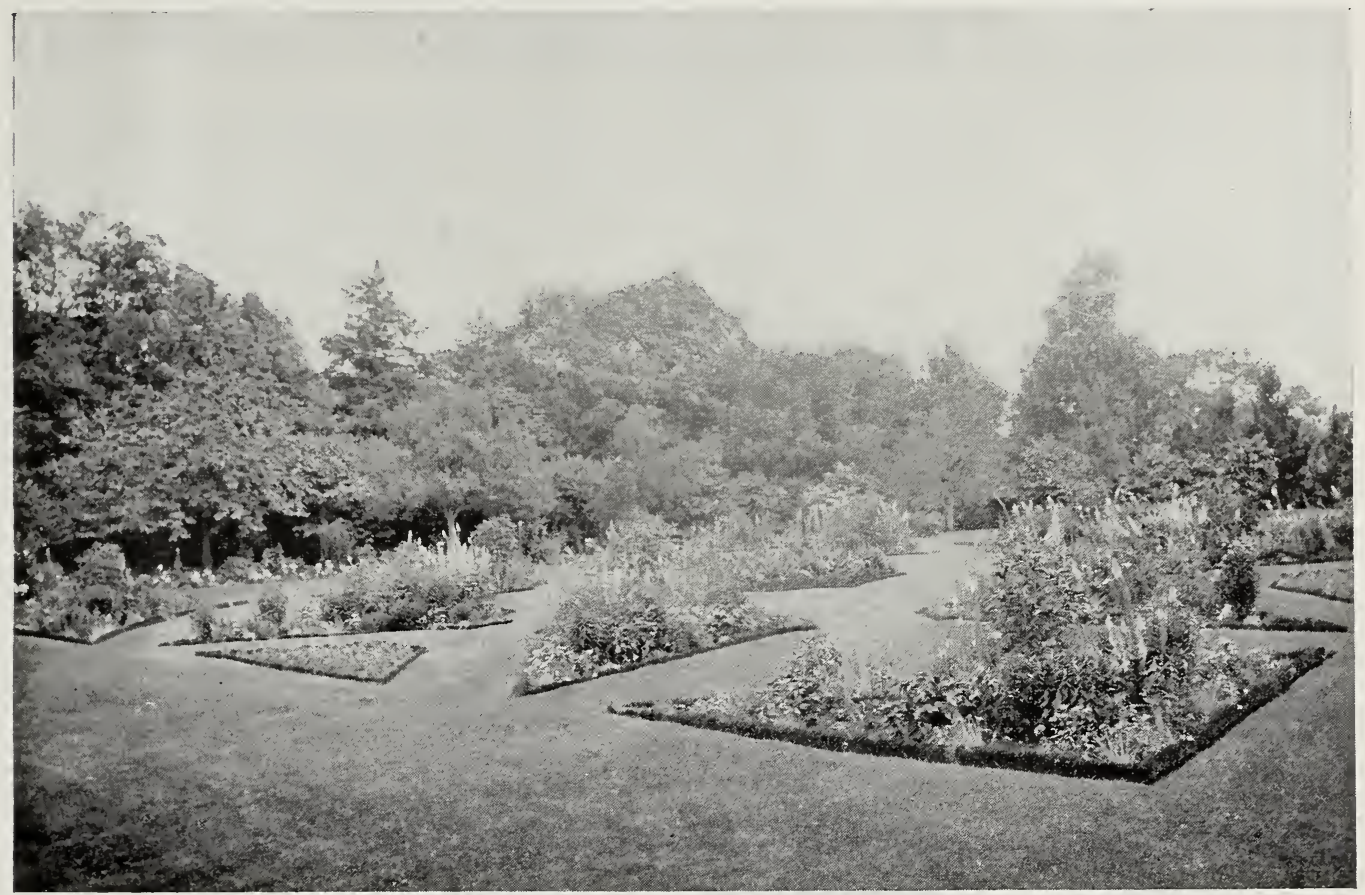

Garden of J. P. Morgan, Esq., Highland Falls, N. Y.

TRITOMA Pfitzeri. (Toroh Lily.) For color effect in orange-scarlet, nothing equals this free-flowering, easily-grown plant. The spikes are 3 to 4 feet high, and heads of bloom 10 to 12 inches long. July to September.

VERONICA. (Speedwell.) The speedwells are mostly natives of New Zealand, flowers being of a blue shade, varying to rose and dull white. They succeed in any garden soil in sunny situations. The low-growing forms are good rock plants.

alpina. Slender, delicate plant, bearing small blue or violet flowers; adapted to the rock-garden.

incana. A dwarf plant with silvery leaves; dark, rich purple flowers.

longifolia subsessilis. A pretty species with blue flowers produced on spikes 1 to $1 \frac{1 / 2}{2}$ feet long, continuing in bloom the entire summer.

spicata. Fine border plant, about 18 inches high, producing spikes of bright blue flowers in summer.

VINCA caerulea minor. (Myrtle, or Periwinkle.) A blue-flowering, trailing evergreen. Excellent for carpeting the ground under trees where grass will not grow. $\$ 1.00$ per doz.; $\$ 7.00$ per 100 .

VIOLA cornuta. (Tufted Pansy.) These plants are becoming general favorites. If planted in a partially shaded bed they will flower for nearly eight months of the year. While the flowers are not as large as those of the pansy, their bright not as large as those of the pansy, their bright
colors will make them welcome additions to the garden. $\$ 1.00$ per dozen; $\$ 7.00$ per 100 .

YUCCA filamentosa. (Adam's Needle.) This has no rival in its peculiar habit and style of growth. The effect of Yucca is equal to that of any hotThe effect of Yucca is equal to that of any hotfor the summer, while they are green and ornamental at all seasons. The Yuccas are so vigorous that it is almost impossible to kill them. When first planted they die down to the ground, but if left alone, they will renew their growth 25 cts. each; $\$ 2.50$ per dozen. Very large, 35 cts. each; $\$ 3.50$ per dozen.

\section{Peonies, Our Great Fall Specialty}

We have omitted from this booklet our superb list of Peonies, because we do not care to ship them in the spring. The peony starts to grow so early that it receives a great setback from spring planting.

Those who intend purchasing are cordially invited to visit the nursery about the middle of June, when the peonies are in bloom, and from our 100 superb varieties, make a selection for fall planting. Those who have visited us in former seasons have marvelled at the extent of our fields and the wealth of bloom. Come and bring your friends!

We have spared neither pains nor expense to procure from the originators many of the most beautiful peonies in cultivation. Giving most careful attention to our fields at peony time for several seasons, we feel positive of the correctness of our varieties, of which our summer catalogue will give a complete list with prices. 


\section{Evergreen Trees.}

The best time to plant evergreens is in the spring. So nuch has been said in the papers the past two or three years about August planting that some have come to believe it is the only time. Those articles were written to induce planters who had failed to plant in spring to do the work in August. This advice is all good, provided the weather is just right and the trees are not far away, but in spring the weather is almost universally right and those who have their ground ready should, by all means, improve their opportunity for spring planting. As evergreens do not start to grow until about a month after the deciduous trees, they may, of course, be planted later; but, as they should be handled with a ball of earth, they are necessarily heavy and need to go by freight if in any quantity. They should not, therefore, be delayed too long until the weather becomes hot and dry.

In addition to directions for planting on page 2, we wish to emphasize the matter of thorough tamping of the earth about the roots of the tree, and if the weather is dry, the tree should be sprinkled daily for a week or ten days to provide against the evaporation until the roots begin to start.

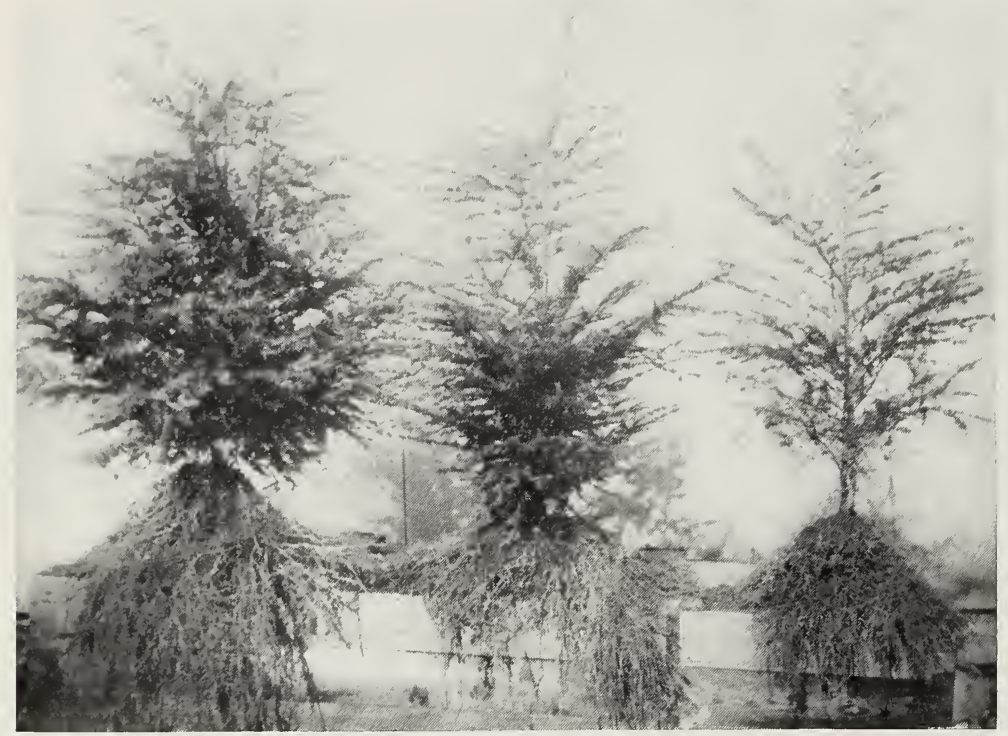

Four Times Transplanted.

Three Times Transplanted. Twice Transplanted.

Photo-engraving of three Hemlock Spruce, each 3 feet high, with ball of earth shaken out to show results of frequent transplanting. Note the increased mass of fiberous roots, also increase fiberous roots, also increase fatness of tops.

All our stock, both deciduous and evergreen trees and shrubs, is frequently transplanted. Our Maples, Lindens, Poplars, Dogwood, etc. show the same masses of fibrous roots as Hemlocks above. In digging. great care is used to preserve the roots intact. We do not use a tree-digging machine. Moreover, our stock is not dug in autumn and stored in cellars, but dug fresh from the ground at time of packing the order. of 600 evergreens sent by freight to Pennsylvania, Spring, 1909, (Arborvitae, 2 to $3 \mathrm{ft}$. high, not balled or burlaped), our customer Arborvitae purchased from Arborvitae purchased from out of 650 purchased elsewhere."

This man not only lost trees and labor, but also a year's time, of more value

\section{Prices and Discounts.}

In comparing prices please note the fact that we make no charge for boxing or packing, or for burlaping the ball of evergreens.

Special prices on $\$ 100.00$ or more, or in car lots.

\section{Abies - Fir}

Abies concolor. (Silvery Fir of Colorado.) Tree of graceful habit; bright, handsome foliage, bluish gracelul hilvery beneath; very distinct and exceedingly above, silvery beneath, very distinct and exceedingly rare. This is one of the best Fir trees, which with-
stands heat, drought and cold. It is very hardy, stands heat, drought and cold. It is very hardy,
grows rapidy and rivals the Nordmanniana in beauty.

$1 \frac{1}{2}$ to $2 \mathrm{ft}$.

2 to $21 / 2 \mathrm{ft}$.

$\begin{array}{llll}21 / 2 & \text { to } & 3 & \text { ft. } \\ 3 & \text { to } & 4 & \text { ft. }\end{array}$

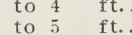

to $6 \mathrm{ft}$.

ft. .

Each

$\$ 2.00$

2.7 .

3.50

4.50

6.00

.

A. Nordmanniana. (Nordmann's Silver Fir.) This variety is native in the mountains of Crimea, where it attains a height of 100 feet. The foliage is of the darkest green, silvered underneath retaining its oolor throughout the year. It contrasts well with
lighter evergreens, is very hardy and of rapid growth.

2 to $2 \frac{1}{2} \mathrm{ft}$

$\$ 2.00$

$21 / 2$ to 3 ft.

$31 / 2$ to 4 ft.

$\begin{array}{llll}4 & \text { to } & 5 & \mathrm{ft} \\ 5 & \text { to } & 6 & \mathrm{ft} .\end{array}$

\section{Biota - Chinese Arborvitae}

Biota elegantissima. (Rollin's Golden Biota.) Very handsome, golden kind, upright in habit, and in the

winter changing to bronze.

2 to $3 \mathrm{ft}$.

$\$ 1.50$

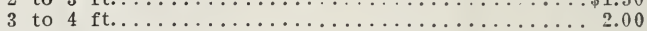

B. nana aurea. A dwarf, rounded form, that is decidedly beautiful in its golden dress.

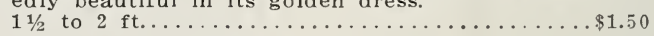

\section{Juniperus - Juniper}

All the Junipers are valuable ornamental plantsthe upright species as single specimens or in groups, and the low forms well adapted for rocky slopes or banks. Junipers thrive best in a sandy, loamy soil, moderately moist, but do well in rocky and gravelly soils in sunny open situations. Excellent for seaside planting.

Juniperus Chinensis. (Chinese Juniper.) A great acquisition from China and Japan; perfectly hardy in hardy evergreens; color a pretty grayish green.

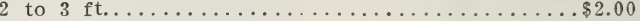

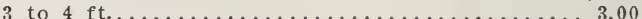

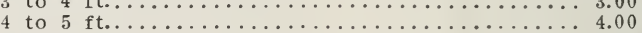

J. C. aurea. (Dwarf, Golden Chinese Juniper.) Upright form, with the young branchlets golden yellow, color becoming very brilliant in full sun.

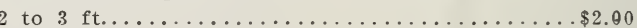

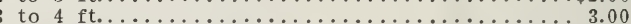

J. Canadensis. Foliage light green; very hardy and a good grower. Decidedly dwarf, never growing more than four feet across the spreading top.

2 to 3 feet, broad.................. \$2.00 
J. aurea. (Douglas Dwarf Golden Juniper.) Very dwarf, spreading form. which turns to a beautiful bronze in winter. Tery suitable for edging groups and in rockeries.

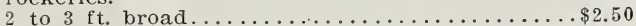

J. C. Hibernica. (Irish Juniper.) Neat and effective with other small evergreens. Not very hardy.

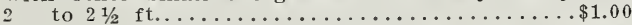

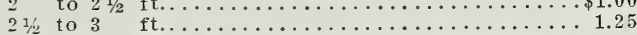

J. Sabina. (Savin's Juniper.) Dwarf-spreading shrub. Grows in the poorest soil. Very valuable for rockeries, borders and groups.

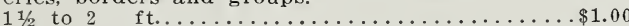

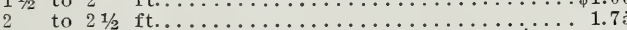

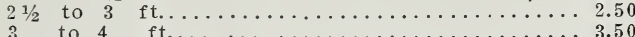

J. Sabina prostrata. Trailing form of Savin's Juniper. Excellent for rockery.

2 to $3 \mathrm{ft}$., broad.

J. c. Suecica. (Swedish Juniper.) A native of northern Europe. Conical, upright-growing bush, from 12 to 20 feet. Very hardy.

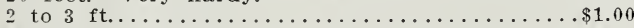

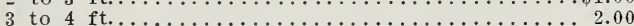

J. Japonica. (Japan Juniper.) Native of China and Japan. A dwarf, dense, bushy evergreen, with light green foliage; forms a compact bush 3 to 5 feet in height.

height.

Japan Golden. Beautiful golden form, holding its

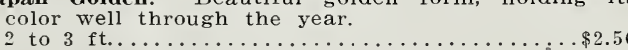

J. oblonga pendula. (Weeping Juniper.) 15 to 20 feet high. Native of the mountains of northern Japan;
perfectly hardy with us; difficult to transplant in larger sizes.

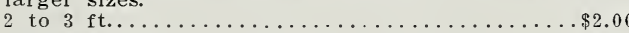

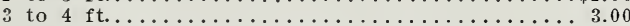

J. repanda. (Recurva.) Shrub or small tree; leaves

glaucous green with a whitish band above.
1 to $2 \mathrm{ft} . \ldots \ldots \ldots \ldots \ldots \ldots \ldots \ldots \ldots \ldots \ldots \ldots \ldots \ldots \ldots \ldots \ldots \ldots \ldots$

J. Virginiana. (Red Cedar.) Fine for formal planting.

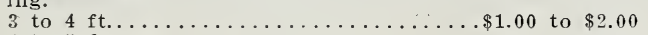

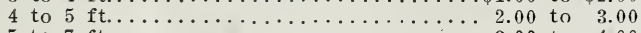

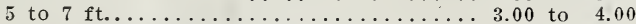

J. V. alba variegata. (Variegated Red Cedar.) Branches variegated with white.

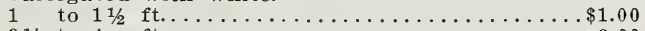

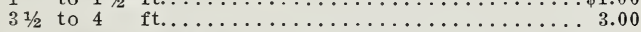

J. V. aurea variegata. Pyramidal in form, like Virginiana, but of finer growth. Keeps its golden color well throughout the year.

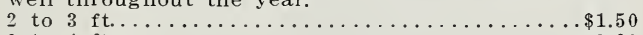

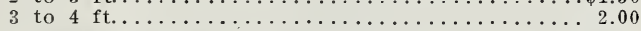

J. V. elegantissima. (Lee's Golden Virginian Juniper.) Beautiful golden hue adorns the tips of the branches. A rapid grower of great beauty.

3 to $4 \mathrm{ft}$......................... $\$ 4.00$

J. V. glauca. (Blue Virginiana.) Of compact, conical habit and bright, silvery foliage.

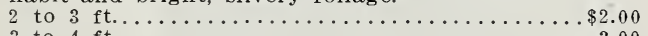

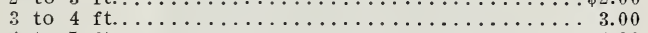

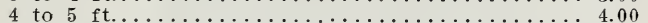

J. V. Schottei. Narrow pyramidal form of Virgiana; fo-

liage light green; superb.

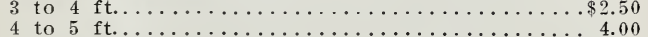

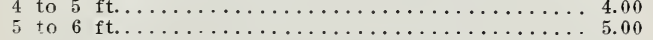

\section{Sciadopitys}

(See cut, page 19.)

Sciadopitys verticillata. Umbrella Pine. Like many others of our choice plants, this beauty comes from Japan. It is unique among evergreens. The peculiar growth of the leaves in parasol-like whorls gives the variety its name. This tree is hardy as far north as Portland, Me., (according to Professor Bailey.) Its compact conical form, glossy, dark green foliage and adaptation to all soils, render it a very desirable and adaptation to all soils, ren
tree. We offer a fine stock.

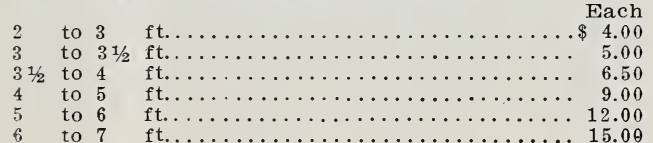

\section{Pinus - Pine}

The pines are essentially inhabitants of the poor, sandy soils and dry situations. Their stout root-system enables them to seek scanty water supplies where other species find it difficult. Some, like the White Pine, are adapted to a variety of soil conditions, but only a few can endure a surplus of water.

Pinus Austriaca. (Austrian, or Black Pine.) A massive and handsome tree of spreading habit. Foliage deep, blackish green. One of the best Pines for forming screens and shelter for more tender trees. Is perfectly hardy and thrives in any moderately dry soil. Flourishes near the sea-coast and on high, bleak hills. Generally loses its beauty after 20 years.

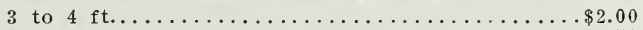

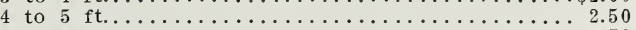

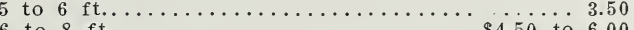

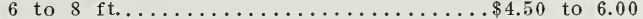

P. Cembra. (Swiss Stone Pine.) This is dwarf, of conical growth; very compact and symmetrical. We consider this one of the choicest dwarf evergreens in the list. We offer a fine stock.

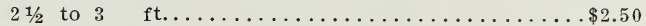

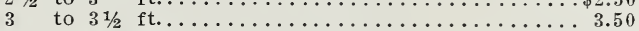

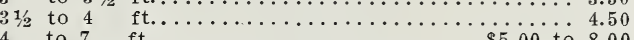
4 to 7 ft...................... $\$ 5.00$ to 8.00

P. Excelsa. (Bhotan Pine.) One of the most beautiful of the pine family. Foliage soft, silvery hue, needles long and drooping; a rapid grower and very hardy; should be planted in poor soil, lest it grow too rapidly. In its native habitat it reaches a height of 150 feet. Taken all in all, it is a great favorite, "having a charmingly graceful habit and soft, pretty, glaucous foliage."

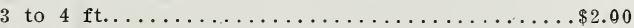

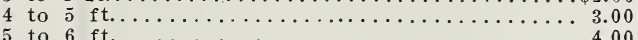

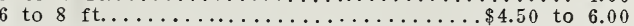

P. Mugho. (Dwarf Mountain Pine.) A bushy species, indigenous to northern Europe. Forms a dense bush and keeps below 4 feet in height for many years.

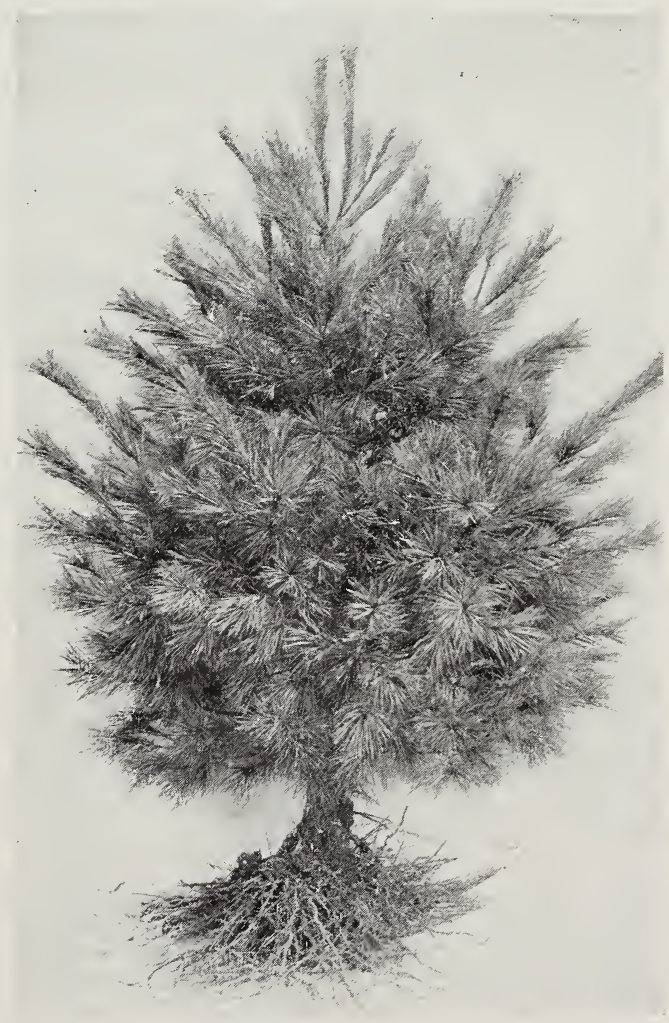

White Pine, 5-6 ft. 


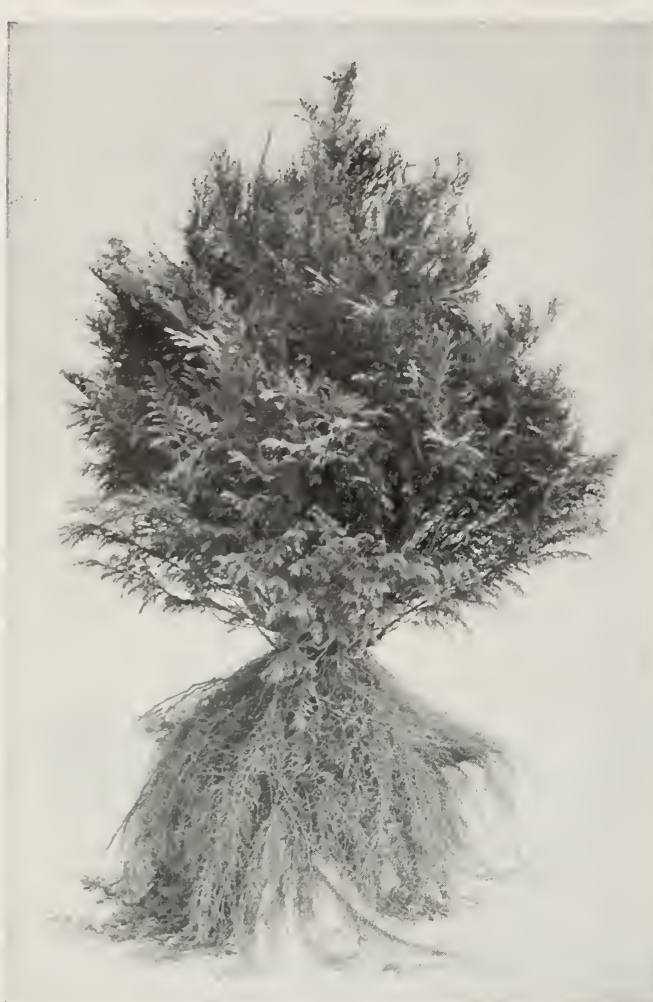

Unsheared Retinospora

This is one of the scarcest varieties in the market. Our stock is unusually fine.

12 to 15 in.............\$50 per $100 \ldots \$ 1.00$ 15 to 18 in., broad.............. 90 per $100 \ldots 1.25$ 18 to 24 in., broad............. 125 per $100 \ldots 1.75$ 2 to $3 \mathrm{ft}$. broad................. $\$ 2.00$ to 3.00

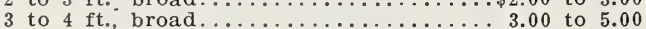

Strobus. White or Weymouth Pine. It is beautiful in every stage of its growth, from a plant to a stately tree of 150 feet. When well established, this tree will grow from $2 \frac{1}{2}$ to 3 feet every year. There is no prettier native Pine than this, and it is easily grown on all soils; in fact, were we to consider its economic importance, its adaptability to climate and soil, or its ornamental use, we must give it chief place among our native pines.

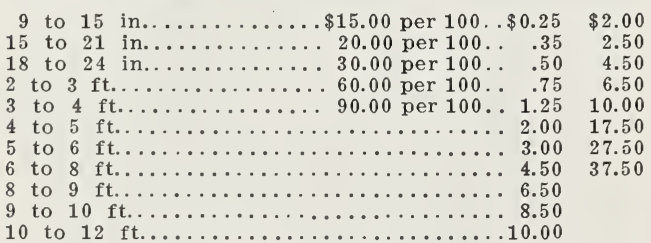

All our pines have been transplanted two to five times and root-pruned, so that they are bound to move with safety. Note the mass of fine feeding roots in the cut and remember our prices include burlaping the ball of earth, in all but the smaller sizes which are not necessary.

\section{Retinispora}

Retinosporas are dwarf and compact, handsome, formal-growing evergreens, particularly useful for the planting of evergreen beds and as specimens in front of larger-growing evergreens. They thrive best in moist soils and situations not too much exposed to wintry gales. No group of evergreens is more used than this for ornamental gardening.
Retinospora flifera. Very graceful, with its long, drooping, tips ending in slender tassels. The color is most beautiful green and the shape pyramidal.

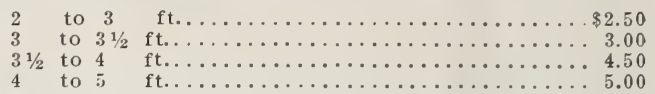

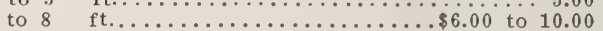

R. f. aurea. This is a dwarf golden variety of the preceding; it is the most graceful of all the Retinosporas; scarce and expensive.

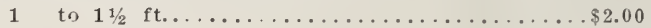

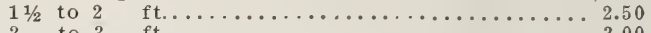

Retinospora pisifera. Fine feathery foliage, with delicate branches.

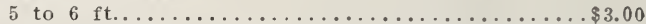

R. p. aurea. A beautiful golden form, with same delicate foliage as Pisifera. Growth tesselated and very wavy; vigorous habit. One of the best.

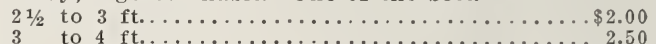

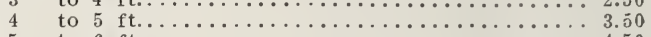

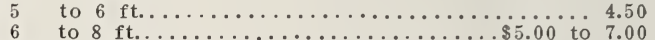

R. plumosa. Light green; soft, feathery plume-like foliage; very graceful habit.

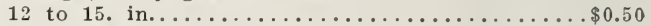

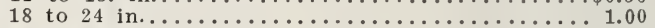

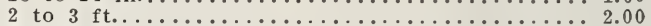

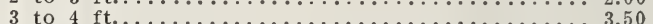

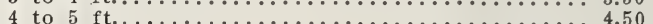

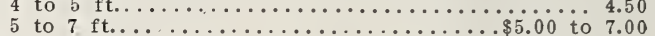

R. p. aurea. One of the most beautiful golden evergreens at all seasons.

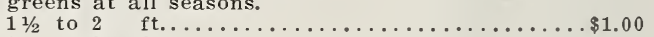

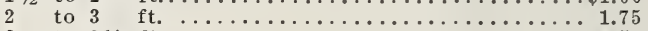

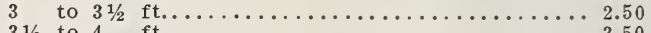

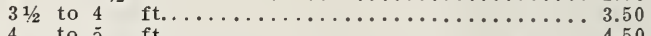
4 to 5 ft......................... 40

to 7 ft......................

striking in appearance and color.

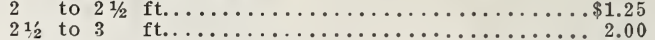

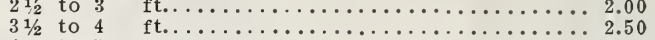

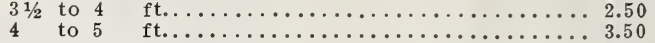
5 to 8 ft....................... 84.50 to 8.00

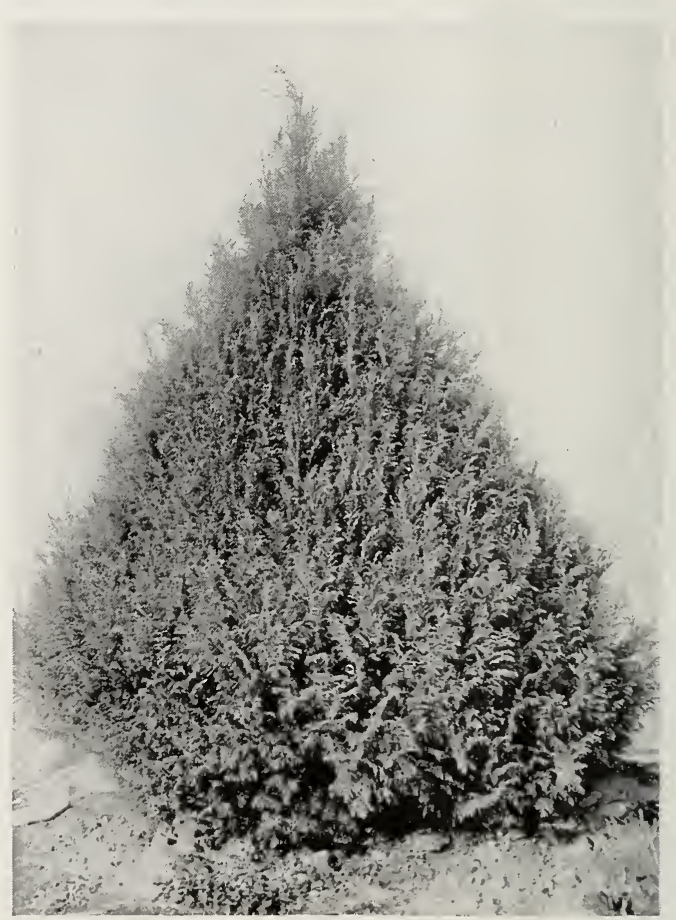

Sheared Retinospora 


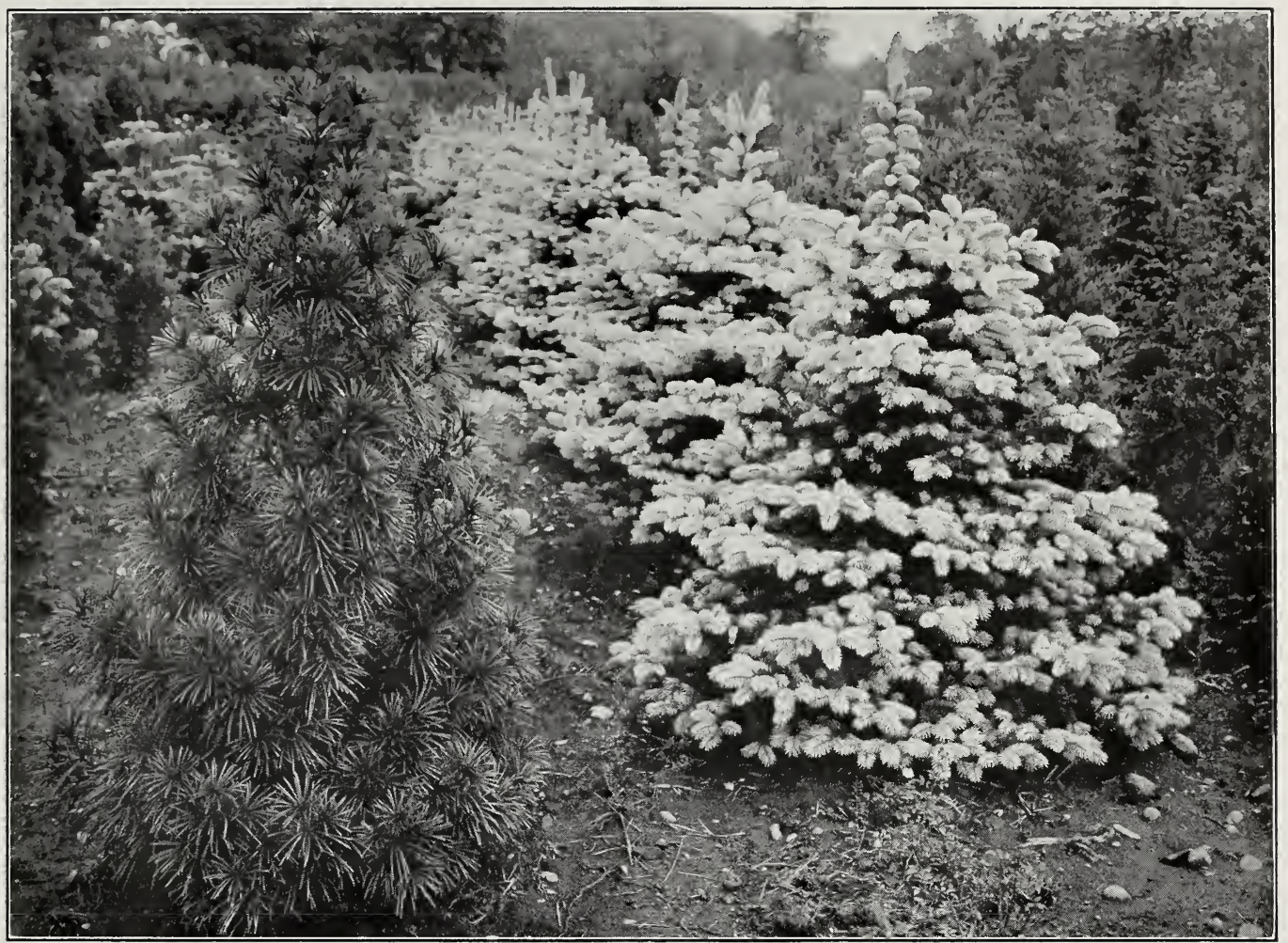

View in our own Nursery showing row of Koster's Blue Spruce at Right and Sciadopitys at Left.

\section{Picea - Spruce}

No group of evergreens is more widely used in landscape work than Spruces, many of which are among the most showy and rapid-growing evergreens; in fact, some of the varieties are almost indispensable, and yet, strange to say, the Norway spruce is the only one that is widely known. This is because it is a very rapid grower, and therefore can be sold cheap. When however, one has seen a well-developed specimen of either Alcock's, Douglas', Koster's Blue, or the Oriental Spruce, price seems of minor inportance. Spruces will grow in almost any kind of soil moderately moist, and are easily transplanted even when quite large.

Picea Alba. (White Spruce.) A native tree of medium size, varying in height from 25 to 50 feet. Of pyramidal form; very shapely in appearance. The foliage is silvery gray; one of the hardiest of evergreens, and is adapted to sections where many others would fail. Will thrive in light moist soils.

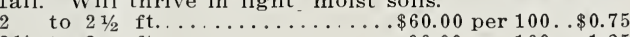
$21 / 2$ to 3 ft............... 90.00 per $100 \ldots 1.25$

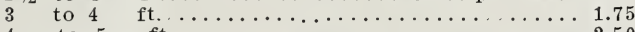

4 to 5 ft.

P. Alcockiana. (Alcock's Spruce.) Faliage pale green, silvery underneath. One of the choicest ornamental evergreens as a specimen on the lawn. Rapid grower; bears cones when young.

2 to $3 \mathrm{ft}$

$\$ 1.25$

P. Engelmanni. (Colorado Spruce.) Resembles the familiar Colorado Blue Spruce; a compact grower and develops into a grand tree.

2 to $3 \mathrm{ft}$.

$\$ 2.00$ 3 to $4 \mathrm{ft}$.

3.00

Picea excelsa. (Norway Spruce.) No evergreen is more generally planted than this, because of its exceedingly rapid growth and extreme hardiness, which adapt it for shelter and massing for effect. It will

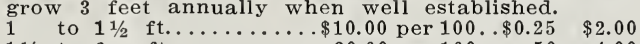
$11 / 2$ to 2 ft............ 30.00 per $100 \ldots .50 \quad 4.00$

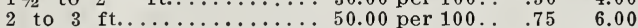

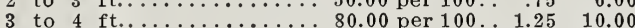

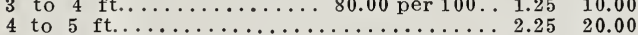

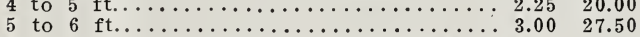

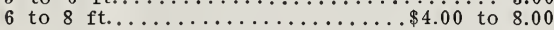

P. e. inverta. (Weeping Norway Spruce.) Very grotesque, with foliage lighter and brighter than the species.

5 to $6 \mathrm{ft}$.

P. nigra Doumetti. (Black Spruce.) A native tree, dwarf and compact in growth, with glaucous foliage. 2 to $3 \mathrm{ft}$.

3 to $4 \mathrm{ft}$.

$\$ 1.50$
2.00

P. p. g. Kosteri. (Koster's Colorado Blue Spruce.) This we consider one of the finest native evergreens; in fact, no finer evergreen exists. Foliage of the richest blue or sage color; perfectly hardy everywhere. All our stock is grafted from the original Koster speoimen and its descendants, and therefore all alike in color. Seeing the splendid form and color of our trees, one customer ordered 200 of them.

2 to $2 \frac{1}{2}$ ft.......\$3.50 $4 \frac{1}{2}$ to $5 \mathrm{ft} . \ldots \ldots \ldots 12.00$ 2 to $21 / 2$ ft......... $\$ 3.50$ to 3 ft. $41 / 2$ to 5 ft................

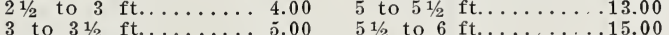

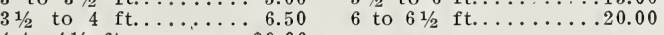
4 to $41 / 2$ ft. . . . . . $\$ 9.00$

P. p. g. pendula. This is the greatest acquisition in conifers in many years. All the branches, even the young shoots, are very drooping; hals the same striking blue color as Koster's Blue Spruce.

3 to $4 \mathrm{ft} \ldots \ldots \ldots \ldots \$ 5.00 \quad 5$ to $5 \frac{1}{1 / 2} \mathrm{ft} \ldots \ldots \ldots \ldots \$ 8.00$

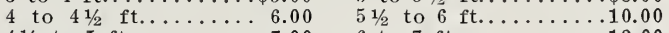

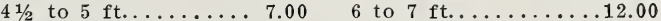

P. orientalis. (Eastern Spruce.) Foliage smaller and more dense than that of the other Spruces; color deep glossy green, brighter and richer than the Norway Spruce; hardy as far north as Boston. Attains a height of 50 to 60 feet. We consider this one of the most elegant of all the conifers.

18 to 24 in......\$1.50 $3 \frac{1 / 2}{2}$ to $4 \mathrm{ft} . \ldots \ldots \$ 4.00$ 2 to $2 \frac{1 / 2}{\mathrm{ft}} \ldots \ldots \ldots \ldots 2.00$ to $4 \frac{1 / 2}{\mathrm{ft} . \ldots \ldots \ldots \ldots} 5.50$

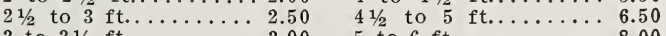

3 to $31 / 2 \mathrm{ft} . \ldots \ldots \ldots 3.00 \quad 5$ to $6 \mathrm{ft} \ldots \ldots \ldots \ldots . . . .60$

New Jersey, Sept. 26, 1911.

The evergreens ordered from you arrived here yesterday forenoon. They are among the finest I have ever seen and I am greatly pleased with them. I enclose my check for $\$ 94.60$. 


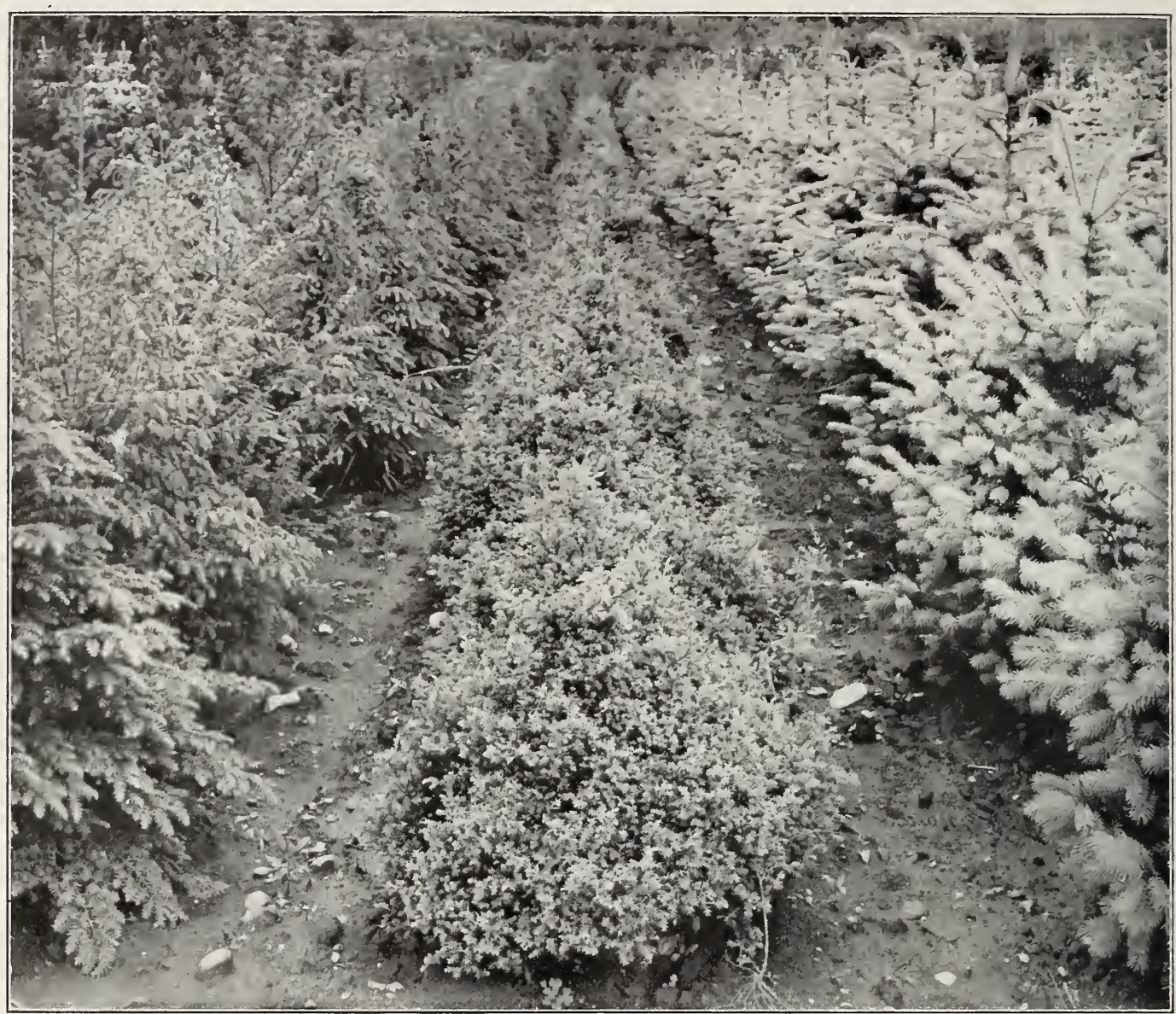

Photograph in our nursery showing a row of Douglas Spruce at the right, Retinispora Squarrosa Veitchii in the center, Hemlock on the left. The beautiful glaucous foliage of the Douglas Spruce is plainly shown in the above photo engraving. In fact, it almost rivals the Colorado Blue Spruce in color. It seems strange that so few have realized the value of this native tree until recent years. It was introduced into England nearly one hundred years ago, where fine specimens have been developed, attaining one hundred and seventeen feet in height with a spread of one hundred feet, retaining their symmetry, in a perfect pyramid, the lower branches being all present and resting on the ground. It transplants very easily and grows as rapidly as a White Pine or Norway Spruce, 2 to $3 \mathrm{ft}$. a year when established. It is not only perfectly hardy, coming from the mountains of Colorado, but endures extreme heat as well.

\section{Prices}

Pseudotsuga mucronata-(Douglas Spruce)

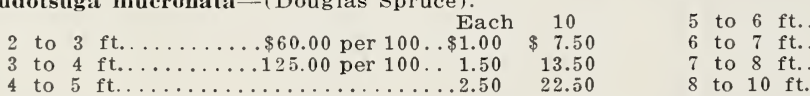

$\begin{array}{cc}\text { Each } & 10 \\ . \$ 3.50 & \$ 30.00 \\ 3.00 & 45.00 \\ 6.00 & 60.00\end{array}$

\section{A Pinetum}

A collection of Pines, Firs, and other evergreens planted where they may be allowed to develop themselves in their full beauty and proportion, called a Pinetum, not only adds great beauty to a large estate because of its contrast of forms and its peculiarities, but permits of growing many more delicate species, which if ex-
posed singly, would perish. It is becoming customary on many fine country estates to select an extensive and suitable locality where many species and varieties may be collected together. To those who have not seen such a planting, it is scarcely conceivable how much they add to the beauty of a country residence. In exposed quarters, also in all bleak situations, groups of evergreens form the most effectual shelter at all seasons of the year. Moreover, many of them may be recommended to grow upon the most meager soil.

The effect produced by evergreens, although the plants may be of small or medium size, is immediate. The symmetrical form and beauty of verdure of young plants is no less effective than the picturesque beauty of the rugged and time-worn tree. No material, therefore, is more adapted for planting new places than are evergreens.

In seleoting evergreens, planters should be cautioned about planting too large sizes and too many of the cheaper varieties. The fact that these varieties are cheap shows that they are of rapid growth, being produced quickly by the nurseryman. This means a rapld-growing tree which more than likely attains a great size and produces a coarse effect. One should select with a view to producing best results at the end of ten or more years. When a tree has been planted a number of years its value will have increased many-fold if it is of the proper variety; if not of a good variety, its value may decrease the older it grows. Of course, for windbreaks and hedges, some of the coarser, cheaper varieties are best; but, for the lawn one cannot too carefully choose varieties which vill increase in value with the years.

Very few of the beautiful evergreens are familiar to planters. It is a revelation to those who go through our nurseries to see the great number of choice varieties, and yet we grow only those which are hardy at the North. 


\section{Taxus - Yew}

The Yews are very desirable evergreens for park planting. They are densely clothed with dark green foliage, well suited for hedges and easily trimmed in any desirable shape. They thrive best in a moderately moist, sandy loam, and endure shade well; easily transplanted if a sufficiently large ball of earth is taken with the roots.

Taxus baceata. (English Yew.) Hardy as far north as Rhode Island and northwestern New York.

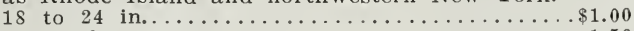

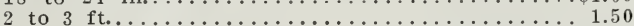

T. b. elegantissima. (Golden English Yew.) One of the most valuable golden-leaved evergreens. In June and July the leaves of the new growth are a bright straw-color, rendering the plant highly effective straw-color, rendering the plant highly effective whether planted alone or with other evergreens; one of the very hardiest of the Yews.

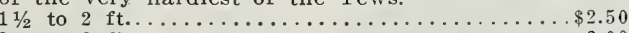

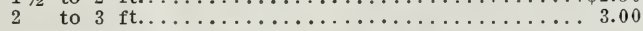

T. cuspidata. Japanese. Beautiful spreading habit foliage light green.

$\$ 2.00$

T. Hibernica. (Irish Yew.) A most beautiful fastigiated form of dark evergreen.

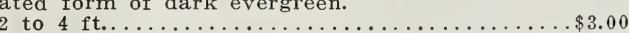

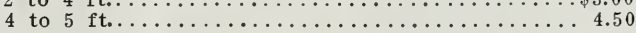

T. H. aurea variegata. Very beautifully striped and margined yellow. Choice specimen plants; perfect pyramidal shape.

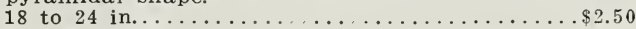

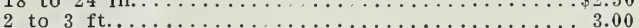

T. Washingtoni. (Washington's Golden Yew.) Foliage variegated, with yellow spots and stripes.

18 to 24 in. with yellow spots and stripes. $\$ 2.00$

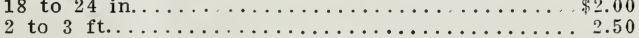

\section{Thujopsis}

Thujopsis borealis glauca. (Nootka Sound Cypress.) A tree of nearly columnar form, growing to a height of 80 to 100 feet. A native of Russia and British Columbia, with ascending branches pendulous at the ends. Resembles the Lawson Spruce, but is more robust and hardy; thrives in any ordinary soil that is not too dry.

T. b. lutea. A distinct form raised in England, having a delicate golden hue at the end of the dark green branches, which renders it one of the most beautiful new evergreens in the list.

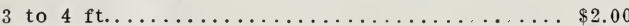

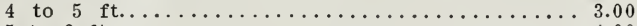

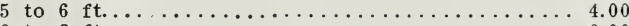

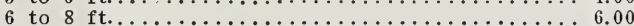

\section{Tsuga - Hemlock}

Tsuga Canadensis. (American Hemlock.) One of the most beautiful native trees; being especially rapid in growth and absolutely hardy, together with the fact that it transplants easily, makes it a very useful evergreen. Its fine feathery foliage and graceful habit make it a great favorite. The best evergreen for hedge-planting. It bears the shears well and may hedge-planting. It bears the shears well and may be kept at any size and shape. Thrives in more shade than most evergreens. If allowed full sunsymmetrically furnished from the ground, thus making a splendid lawn specimen.

18 to 24 in...........\$60.00 per $100 \ldots \$ 1.00 \$ 7.50$ 2 to $21 / 2$ ft............ 75.00 per $100 \ldots 1.2510 .00$ $21 / 2$ to 3 ft....................... $21 / 2$ to 3 ft....................... 1000 per $100 \ldots$ 3 to $31 / 2$ to 4 ft...................

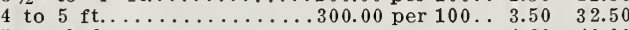

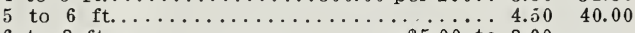

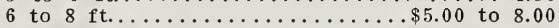

T. Caroliniana. (Southern Hemlock.) A native of the mountains of the southern states. This beautiful tree, with its dark green foliage, makes a great addition to our hardy northern ornamental evergreens.

3 to $4 \mathrm{ft}$.

. 4.50

T. C. Sargentii pendula. (Sargent's Weeping Hemlock Spruce.) Originated at "Wodenethe" Mr. Sargent's estate at Fishkill, N. Y. It has not been as generally planted as it should be, owing to its slow growth and high cost of production. When well grown it makes a picture. Like most weeping trees, no two plants take quite the same form. If this variety were more easily propagated, so that it could be sold at a lower price, it would be in very great

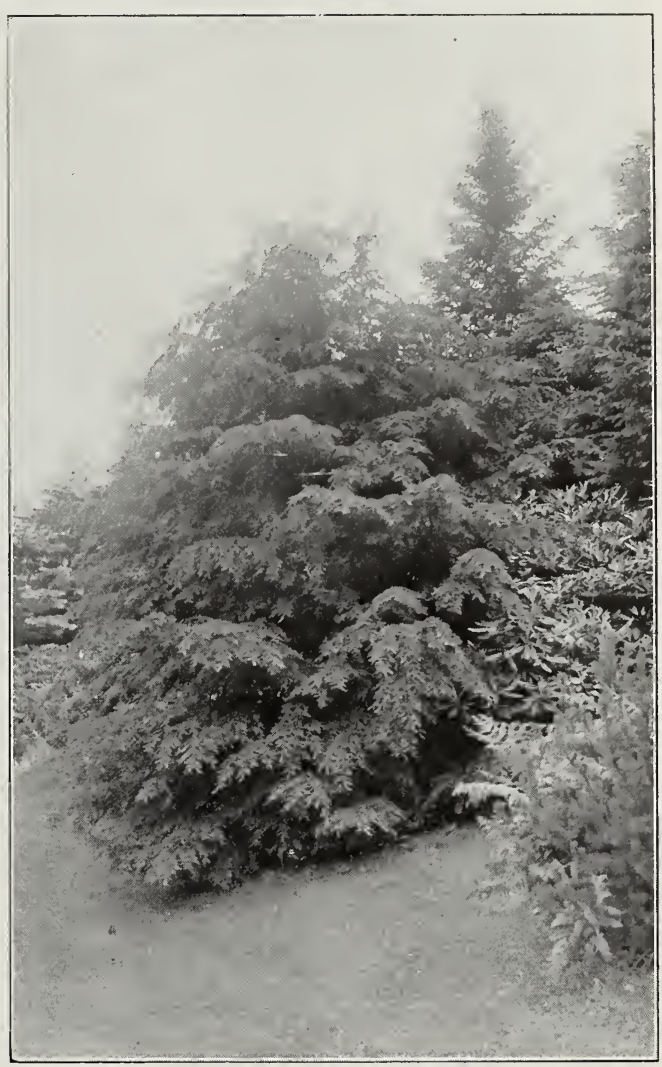

Hemlock (Tsuga Canadensis)

demand, as it is one of the most beautiful of all weeping trees.

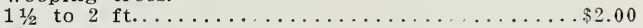

2 to $21 / 2 \mathrm{ft}$.

3.00

\section{Thuja - Arborvitae}

Ornamental evergreen trees of narrow, pyramidal habit. Thujas are favorites for formal gardens because of their regular, symmetrical habit. Well adapted for hedges and windbreaks. They thrive best in a somewhat moist, loamy soil; easily transplanted.

Thuja occidentalis. (American Arborvitae.) Beauti-

ful native cree, commonly known as the White

Cedar. Especially useful for hedges and screens.

$11 / 2$ to $2 \mathrm{ft} \ldots \ldots \ldots \ldots \ldots \ldots \ldots \ldots \ldots \ldots \ldots \ldots \ldots \ldots \ldots \ldots+35.00$ per $100 \ldots \$ 0.35$

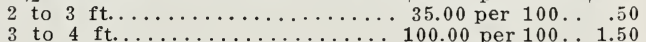

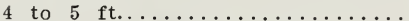

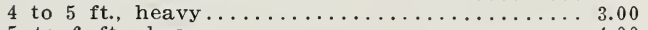

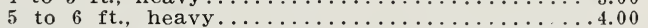

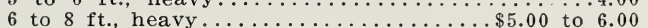

8 to $10 \mathrm{ft}$, heavy...........................

T. o. compacta. A very dwarf, densely branched variety which assumes an oval form. The foliage is richly colored and very beautiful. Much used in planting evergreen borders or beds; also for cemetery and house decoration.

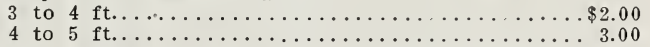

T. o. Ellwangeriana. Small, compact variety, dwarf and very graceful.

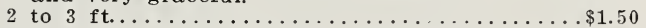

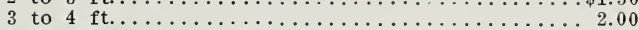

T. o. globosa. (Globe-headed Arborvitae.) Dense, low bush, with rich green foliage; keeps its color well through the winter.

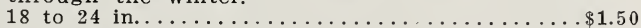

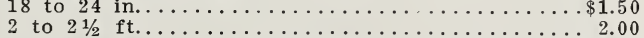

T. \%. Hoveyi. (Hovey's Golden Arborvitae.) Dwarf seedling from the American. Globular outline and bright green foliage with a golden tinge.

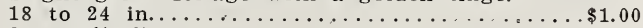

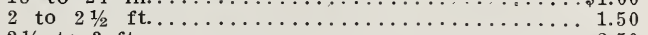

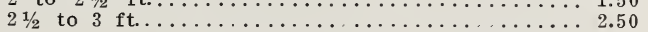




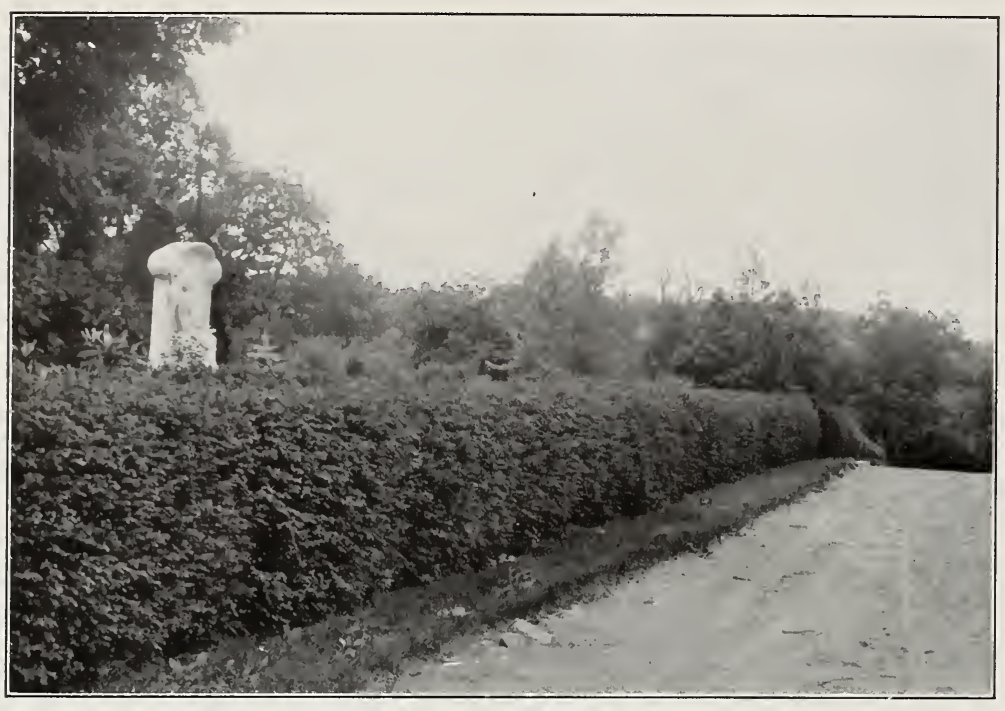

Hemlock Hedge planted by us on the Willard Plot Sleepy Hollow Cemetery,
T. o. Little Gem. Very dwarf, rarely attaining over a foot in height.

12 to 15 in. broad.

$\$ 1.50$

T. occidentalis lutea. (Peabody's Arborvitae.) Finest and hardiest of the golden Arborvitaes. Its golden hue is the brightest and most permanent. Makes a fine contrast with darker-colored evergreens. 3 to $4 \mathrm{ft}$.

$\$ 4.00$ to 3.00

T. o. pyramidalis. (Pyramidal Arborvitae.) The deep green color and upright, pyramidal form of this species renders it conspicuous in contrast with other evergreens. It is very hardy and vigorous. 3 to $4 \mathrm{ft}$.

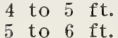

6 to $8 \mathrm{ft}$.

$\$ 1.50$

2.25
3.00

$\$ 4.00$ to 5.00

T. o. Siberica. One of the most useful of the Arborvitaes. It forms a beautiful compact specimen, without shearing; foliage is full and of a peculiar dark green color throughout the year.

18 to 24 in.

$\$ 1.00$

3 to $3 \frac{1}{2} \mathrm{ft}$.

$\$ 1.50$

2.50

T. o. Tom Thumb. Dwarf variety originated in Rochester. It is remarkable for its slow growth and compact, symmetrical habit. Useful for decoration of gardens or cemeteries where large trees may not be used; also for small evergreen hedges. $1 \mathrm{ft}$. $\$ 1.50$.

T. o. Vervaeneana. A distinct and handsome yellow variety of the American Arborvitae.

4 to 5 ft. 5 to $6 \mathrm{ft}$.

6 to $8 \mathrm{ft}$

$\$ 2.50$

3.50

\section{Rhododendron - Rosebay}

The Rhododendrons are certainly without a rival among hardy flowering shrubs, either for making a magnificient display of bloom in May or June, or for rich, massive foliage at all seasons of the year. They are steadily increasing in popularity as planters learn better how to manage them. They like a light soil in which there is plenty of peat or leaf-mould, and prefer partial shade. After the flowers have faded, the seed-pods should be removed, in order that the plant may use all its vigor to form bloom buds for the following season. About the middle of July the plants should be well mulched to guard against drought, to which they are very sensitive.

Named varieties thoroughly tested for hardiness, will give perfect satisfaction.

Album elegans. French white.

Atrosanguineum. Deep scarlet.

caractacus. Fine purplish crimson; large truss.

Charles Dickens. Red, shaded crimson.

Delicatissimum. Blush-white.

Everestianum. Rosy-lilac; large truss.
Chas. Bagley. Bright cherry President Lincoln. Rose. Alba grandiflorum. Blush. Lady Armstrong. Rosy pink. Mrs. Milner. Rich crimson. Mrs. R. S. Holford. Salmonrose.

Old Port. Plum color

Roseum elegans. Rose color. Stella. Lilac, chocolate blotch. Parson's Gloriosa. Lilac.

\section{Rhododendron Maximum}

\author{
Great Laurel
}

This is the native Rhododendron which blooms in midsummer and makes the wooded hillsides and mountains of the eastern and middle states so magnificent with their white, blush and delicate pink flowers. They are used in great numbers on large estates, being much cheaper than the grafted varieties, and more suitable in certain locations, although the bloom is not so attractive as that of the latter.

A mass of these superb sinrubs were planted in the spring of 1900 , under the trees where grass could not be made to grow, on one of the finest estates in Ossining. Every plant did well, notwithstanding the season was the most trying for many years. This is about the only plant that will succeed in such dense shade where grass will not grow at all. My foreman has had large and successful experience in handling this native Rhododendron and Kalmia latifolia (Mountain Laurel) and knows just how to select and lift with large balls of earth, so that the plants are sure to grow.

Plants carefully selected, well set with buds, bushy nearly to the ground, and lifted with large balls of earth, give universal satisfaction. The fact that I sell thousands of these plants every year and ship to the same buyers two and three years in succession proves not only the quality but the price to be correct.

Sizes run from 1 to 6 feet in height, with diameter nearly equal to height. Sizes will be graded, or any particular sizes selected as desired. Superb plants. Special prices on car and half-car lots. A mass of these native Laurels bordered with the choice grafted sorts we import from England, makes the greatest adsorts we import from England, makes the
dition possible to the shrubbery planting.

\section{Kalmia - Mountain Laurel}

Kalmia latifolia. Next to the rhododendron in beauty, this native shrub is being planted extensively in the finest landscape work. For cut-flowers it is most satisfactory. Cut in the bud they will last in bloom in vases of water for two weeks. It blooms later than the named varieties of rhododendrons, and earlier than Rhododendron maximum. The Kalmia thrives well in sandy or loamy soil, but dislikes clay or limestone. It grows almost as well in swamps as in drier locations and prefers partly shaded situations. Requires same treatment as rhododendrons. The thick, shiny leaves are conspicuous the year round, making it a shrub of great value for massing in evergreen effect. It is one of our most hardy shrubs, being found sparingly in Nova Scotia, and very abundantly in New England, along the Alleghenies, through Carolina and as far south as Florida. It is, therefore, a valuable shrub for all sections. Car and half-car lots priced on application. We also offer fine nursery-grown on application. We
stock, well budded.

\section{6,000 TREES}

Sold to one man in nine years is the enviable reputation of ROSEDALE NURSERIES. A trial order brought larger orders from year to year, culminating in January, 1912, with an order for 10,000 EVERGREENS 


\section{Shrubs in Tree Form}

Acacia. 4 to $7 \mathrm{ft}$., $\$ 2$ each. Azalea Mollis. $\$ 1.50$ to $\$ 2$ each. Box. See Evergreen Shrubs, below. Caragana. $\$ 1$ to $\$ 1.50$ each. Caragana. $\$ 1$ to $\$ 1.50$ each.
Forsythia. $\$ 1$ to $\$ 1.50$ each.

Hydrangea. 50 ets. to $\$ 1$.

Lilac. $\$ 1$ to $\$ 1.50$ each.

Viburnum (Snowball). 75 cts. to $\$ 1.25$ each.

Wistaria. $\$ 1$ to $\$ 3$ each.

\section{Evergreen Shrubs Hardy}

Rhododendron. We offer all bushy and well budded, field grown plants from a celebrated English grower. Larger sizes have been three years in our grounds.

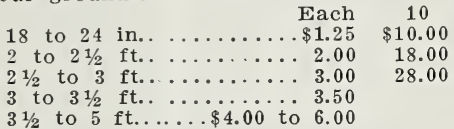

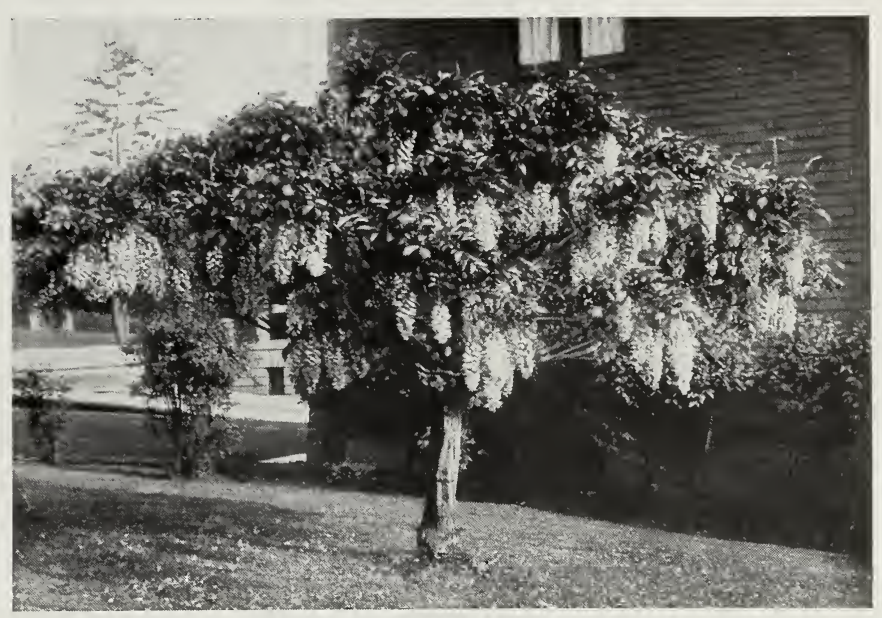

$3 \frac{1}{2}$ to $5 \mathrm{ft} . \ldots \ldots \$ 4.00$ to 6.00 Each grown three years in our nursery.

10

Wistaria in Tree Form

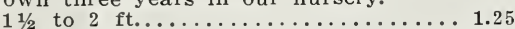

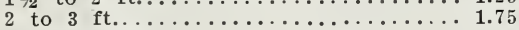

Azalea amoena-

10 to 12 in........... $\$ 40$ per 100.75

12 to 18 in.; 18 in. broad.. 70 per 100.1 .00
20 to 24 in.; 2 ft. broad...100 per 100 . 1.50

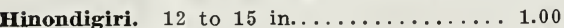

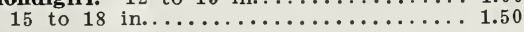

Yodogami. $1 \frac{1 / 2}{2}$ to $2 \mathrm{ft} . \ldots \ldots \ldots \ldots \ldots \ldots$

Kalmia latifolia-Nursery grown.

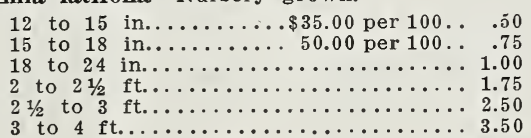

10.00

15.00

5.00

8.50

12.50

eucothe Catesbaei. 12 to 18 in ........ .25

18 to 24 in..........................

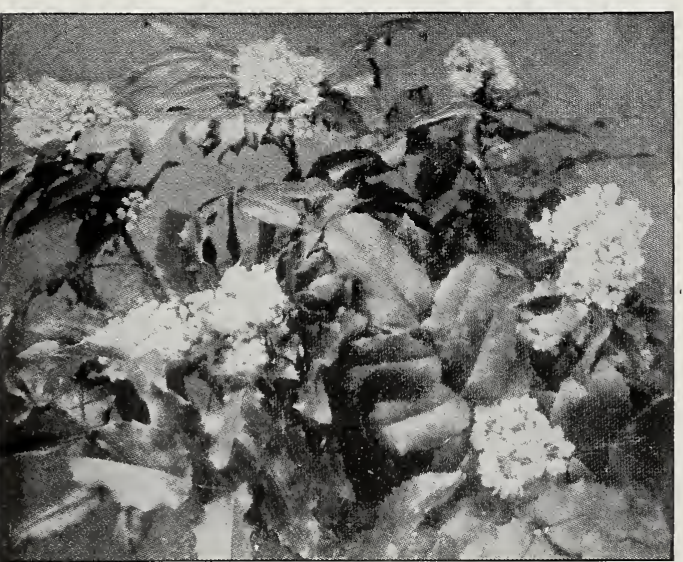

Mahonia aquifolium

4.00 6.00 9.00 15.00 20.00 32.00
Mahonia aquifolia-

12 to 18 in........ $\$ 15.00$ per $100 \ldots \$ 0.25 \quad \$ 2.00$

18 to 24 in............ 30.00 per $100 \ldots .40 \quad 3.50$

2 to $21 / 2 \mathrm{ft} \ldots \ldots \ldots \ldots 40.00$ per $100 \ldots .60 \quad 5.00$

Boxwood Trees. Pyramidal Shape- Each

30 to 36 in. high, 15 in. diam at base..... \$2.50

36 to 42 in. high; 15 to 18 in. diam. at base... 3.00 42 to 48 in. high; 18 to 24 in. diam. at base... 4.00 48 to 50 in. high; 2 to $3 \mathrm{ft}$. diam. at base.... 5.00

54 to 60 in. high; $3 \mathrm{ft}$ diam. at base....... 6.60

Boxwood Trees. Standard or tree-shaped-

Stem 30 in. high; diam. of crown 12 to 16 in... 2.00 Stem 30 in. high; diam. of crown 16 to 18 in. . 3.00 Stem 30 in. high; diam. of crown 18 to 22 in... 4.00 Stem 30 in high: hiam of crown 22 to 24 in... 5.50 Stem 30 in. high; diam. of crown 24 to 30 in... 7.00 Per 100 Per 1,000

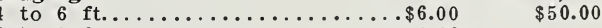
6 to $8 \mathrm{ft} . \ldots \ldots \ldots \ldots \ldots \ldots . \ldots \ldots . \ldots \ldots$

Bushes-

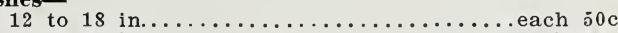

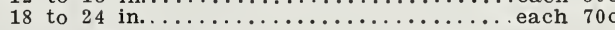
Box Handsworthii-

2 to $3 \mathrm{ft} ., 2 \mathrm{ft}$. broad..............each $\$ 1.00$

\section{Leucothoe}

Leucothoe Catesbaei. (Drooping Andromeda.) Most beautiful dwarf shrub for either shade or sun: the long leathery leaves take on a beautiful bronze in autumn and winter. Beautiful for Christmas decoration; dainty racemes of white or pink bellshaped flowers cover drooping stems.

\section{Mahonia}

Mahonia aquifolium. (Holly-leaved Mahonia.) Beautifulhona acou shiny, purplish leaves turn to the finest bronze and shiny, purplish leaves turn to the finest bronze and
crimson. In spring the whole picture changes-the crimson. In spring the whole picture changes-the polished leaves are green a gain ather plant then in bloom. Grows 4 to 5 feet high. Take it all in all, we consider the Mahonia one of the most valuable of all shrubs, deciduous or evergreen, since it does as well in sun as in the shade. It is perfectly hardy, a most rapid grower, with very attractive yellow a most rapid grower, with very attractive yellow flowers in the spring and succeeded by purplish berries in autumn. While it is evergreen, it has what is even better, a most superb brown, rich tone, mingled with the most gorgeous scarlet and crimson, and leaves covered with a brilliant luster-like varnish. It is much improved by keeping it back by occasional clipping, as it sometimes has a tendency to straggle.

From Maine.

"I wish it were possible for me to describe to you the interest and admiration that our three year old Mahonia hedge has aroused from friends and passers-by. From our secluded porch we have some days counted as many as twenty who have exclaimed at its beauty, strangers sometimes coming up to ask the name of the hedge ,also of the nurseryman."

very truly yours, 


\section{Deciduous Trees}

\begin{tabular}{|c|c|c|}
\hline thus glandulosa. 5 to $6 \mathrm{ft} \ldots \ldots \ldots \ldots$ & $\begin{array}{l}\text { Each } \\
. \$ 0.30\end{array}$ & $\begin{array}{l}10 \\
\$ 2.50\end{array}$ \\
\hline der Imperial. 4 to $6 \mathrm{ft} \ldots \ldots \ldots \ldots \ldots$ & 1.00 & 7.50 \\
\hline Imond. Tree Form. 3 to $4 \mathrm{ft} \ldots \ldots$. & .35 & 3.00 \\
\hline $\begin{array}{l}\mathbf{h}, \text { American White. } 6 \text { to } 8 \mathrm{ft} \ldots \ldots \ldots \ldots \\
8 \text { to } 10 \mathrm{ft} . \ldots \ldots \ldots \ldots \ldots \ldots \ldots \ldots \ldots \ldots\end{array}$ & $\begin{array}{r}.75 \\
1.00\end{array}$ & $\begin{array}{l}6.00 \\
7.50\end{array}$ \\
\hline European. 7 to $8 \mathrm{ft} \ldots \ldots \ldots \ldots \ldots$ & .50 & 4.00 \\
\hline 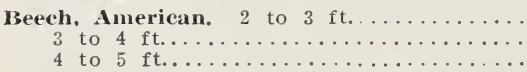 & $\begin{array}{l}1.00 \\
1.25 \\
1.75\end{array}$ & $\begin{array}{r}7.50 \\
10.00 \\
15.00\end{array}$ \\
\hline $\begin{array}{l}\text { Cut - and Fern-leaved. } 2 \text { to } 3 \mathrm{ft} \ldots \ldots \ldots \ldots \\
3 \text { to } 4 \mathrm{ft} . \ldots \ldots \ldots \ldots \ldots \ldots \ldots \ldots \ldots\end{array}$ & $\begin{array}{l}1.00 \\
1.50\end{array}$ & $\begin{array}{r}7.50 \\
12.50\end{array}$ \\
\hline 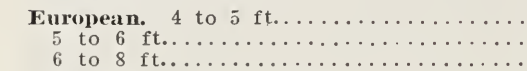 & $\begin{array}{l}1.00 \\
1.50 \\
2.50\end{array}$ & 7.50 \\
\hline 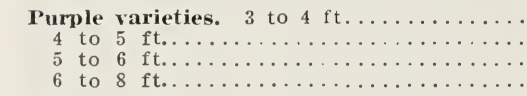 & $\begin{array}{r}1.00 \\
1.50 \\
2.00 \\
2.50\end{array}$ & \\
\hline 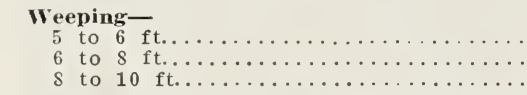 & $\begin{array}{l}1.50 \\
2.00 \\
2.50\end{array}$ & \\
\hline
\end{tabular}

These are superb trees and carry a mass of roots which insure safe transplanting. Transplanted 1911.

\begin{tabular}{|c|c|c|}
\hline $\begin{array}{l}\text { ch, Cut-leaved Weeping. } 6 \text { to } \delta \text { ft... } \\
8 \text { to } 10 \text { ft. } \ldots \ldots \ldots \ldots \ldots \\
10 \text { to } 12 \text { ft. } \ldots \ldots \ldots \ldots\end{array}$ & $\begin{array}{l}1.75 \\
2.00\end{array}$ & \\
\hline 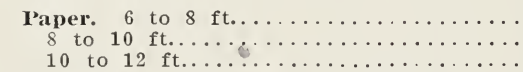 & $\begin{array}{l}1.00 \\
1.50 \\
2.00\end{array}$ & $\begin{array}{r}8.00 \\
12.00 \\
17.50\end{array}$ \\
\hline 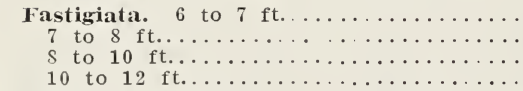 & $\begin{array}{l}1.25 \\
1.50 \\
2.50 \\
3.50\end{array}$ & $\begin{array}{l}10.00 \\
12.00\end{array}$ \\
\hline 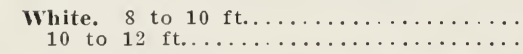 & $\begin{array}{l}1.00 \\
1.50\end{array}$ & $\begin{array}{r}8.00 \\
12.00\end{array}$ \\
\hline
\end{tabular}

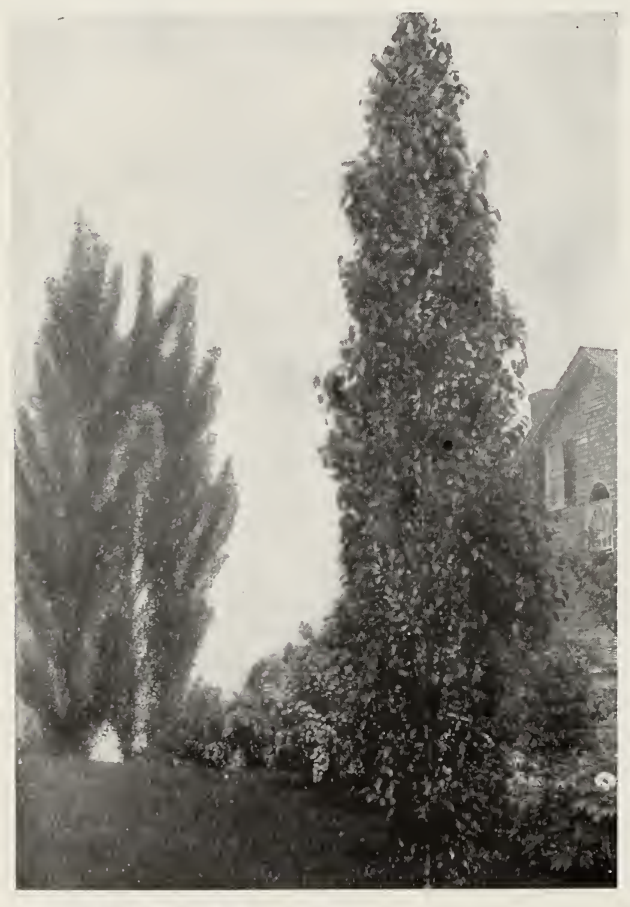

Lombardy Poplar

Pyramidal Birch

Added to the formal effect the white bark of the Birch makes it very attractive.
Young's Weeping. 5 to $7 \mathrm{ft} \ldots \ldots \ldots$ Each

Buttonwood. See Plane.

Catalpa Bungei. 1-yr. heads.......... $\$ 1.00$

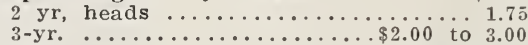

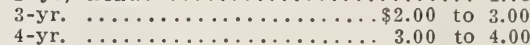

Speciosa. 5 to $6 \mathrm{ft} \ldots \ldots \ldots \ldots \ldots \ldots \ldots .25$

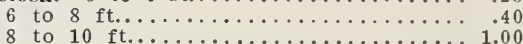

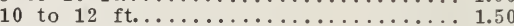

Chestnut. 5 to $7 \mathrm{ft} \ldots \ldots \ldots \ldots \ldots \ldots \ldots . . . \ldots \ldots$

Cherry, Flowering. 3 to $4 \mathrm{ft} \ldots \ldots \ldots \ldots \ldots . .75$

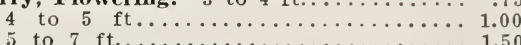

Coffee Tree. 6 to $8 \mathrm{ft} . \ldots \ldots \ldots \ldots \ldots \ldots . \ldots 1.00$

Crab Apples, in variety. 2 to $3 \mathrm{ft} . \ldots \ldots \ldots .50$

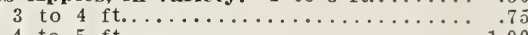

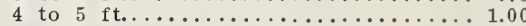

Cypress, Deciduous. 4 to $5 \mathrm{ft} . \ldots \ldots \ldots .75$

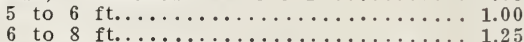
6 to $8 \mathrm{ft} \ldots \ldots \ldots \ldots \ldots \ldots \ldots \ldots \ldots \ldots \ldots \ldots \ldots$ like evergreen; its lace-like light green foliage; it is very attractive.

Dogwood, White-flowering. 2 to $3 \mathrm{ft} \ldots . . .40 \quad 3.00$

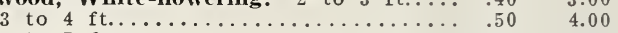

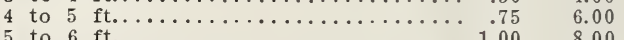

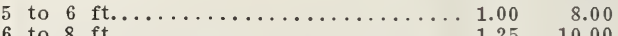

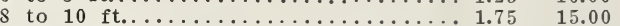

Pink-flowering (rubra). 3 to $4 \mathrm{ft} \ldots \ldots 1.50 \quad 12.50$

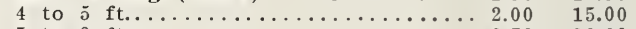

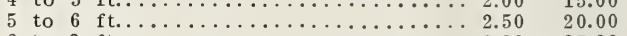

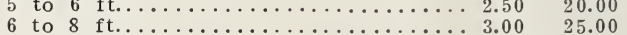

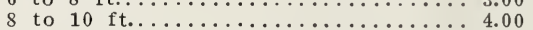

EIm, American. 6 to 8 ft............. 75 . 6.00 8 to $10 \mathrm{ft} \ldots \ldots \ldots \ldots \ldots \ldots \ldots \ldots \ldots \ldots \ldots \ldots \ldots \ldots, 1.25 \quad 10.00$ $11 / 4$ to $1 \frac{1}{2}$ in. caliper...................... $1.50 \quad 12.00$ $11 / 2$ to $13 / 4$ in. caliper...................... $1.75 \quad 15.00$ $13 / 4$ to 2 in. caliper...............

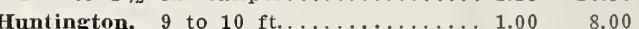

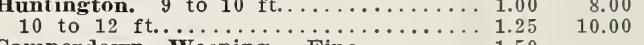
Camperdown, weeping. Fine........... 1.50

Fringe, White. 3 to $4 \mathrm{ft} \ldots \ldots \ldots \ldots \ldots \ldots .75$

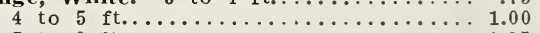

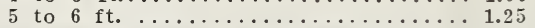

Hornbeam (Carpinus) European- $100 \ldots \quad .50$ 4 to $5 \mathrm{ft} . \ldots \ldots \ldots \ldots \ldots 25.00$ per $100 \ldots .50$ Horse-Chestnut, Common White-

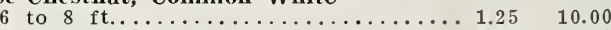
Double white. 6 to 8 ft............... $2.00 \quad 17.50$

Double Red. 5 to $6 \mathrm{ft} \ldots \ldots \ldots \ldots \ldots \ldots 1.50 \quad 12.50$

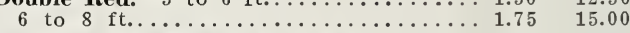

Judas Tree, American. 3 to $4 \mathrm{ft} \ldots \ldots \ldots \ldots .50 \quad 4.00$ 4 to 5 ft........................ $75 \quad 6.00$ Japanese. 18 to 24 in.................... .35 2 to $3 \mathrm{ft} . \ldots \ldots \ldots \ldots \ldots \ldots \ldots \ldots \ldots \ldots \ldots \ldots, .50 \quad 4.00$

Koelreuteria paniculata. 5 to $6 \mathrm{ft} \ldots \ldots \ldots \ldots, 1.00 \quad 7.50$ 6 to $7 \mathrm{ft}$.............................. $1.25 \quad 10.00$

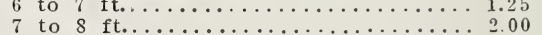

Laburnum. 5 to $7 \mathrm{ft} \ldots \ldots \ldots \ldots \ldots \ldots . .75$ Larch, European. 5 to $6 \mathrm{ft} \ldots \ldots \ldots \ldots \ldots 1.00$ 6 to 8 ft....................... 1.25

Leptolepsis (Japanese). 4 to $6 \mathrm{ft}$..........75

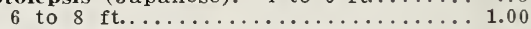

Liriodendron. See Tulip Tree.

Linden, American. 10 to $12 \mathrm{ft} . \ldots \ldots \ldots \ldots$. 1.50 Broad-leaved. 8 to $10 \mathrm{ft} . \ldots \ldots \ldots \ldots 1.50$ 10 to $12 \mathrm{ft} . \ldots \ldots \ldots \ldots \ldots \ldots \ldots \ldots \ldots \ldots \ldots, 1.75$

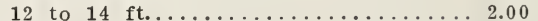

Red-twigged. 8 to $10 \mathrm{ft} \ldots \ldots \ldots \ldots \ldots \ldots, 1.25$

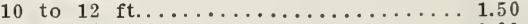

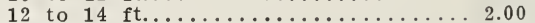

Weeping. 7 to $8 \mathrm{ft} \ldots \ldots \ldots \ldots \ldots \ldots . . .2 .00$

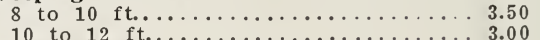

White-leaved. 5 to $6 \mathrm{ft} \ldots \ldots \ldots \ldots \ldots, 1.00$ 9 to $10 \mathrm{ft} . \ldots \ldots \ldots \ldots \ldots \ldots \ldots \ldots . .2 .00$
8.00

10.00

6.00

8.00

12.50

12.50

15.00

10.00

12.50

17.50

17.50

22.50 


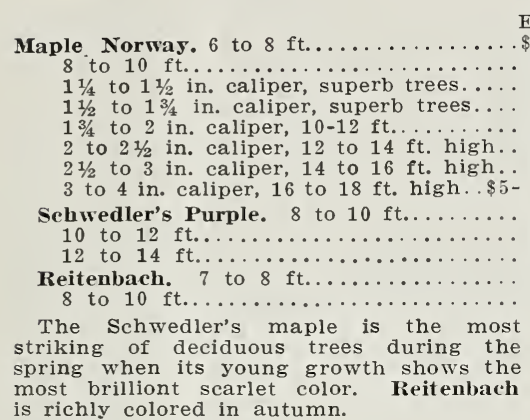
sichly colored in autumn.

Sugar. 8 to $10 \mathrm{ft} \ldots \ldots \ldots \ldots \ldots \ldots \ldots \ldots \ldots$

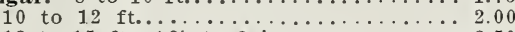

12 to $15 \mathrm{ft.,} 13$ to 2 in............ 15 to $20 \mathrm{ft.,} 2 \mathrm{in}$. and up.... 8.50

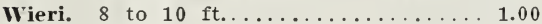

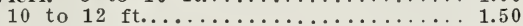

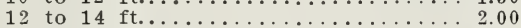

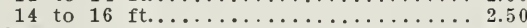

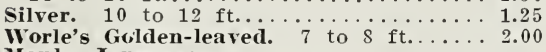

Polymorphum $2 \frac{1}{2}$ to $3 \mathrm{ft} . \ldots \ldots \ldots \ldots 1.75$

3 to $4 \mathrm{ft} \ldots \ldots \ldots \ldots \ldots \ldots \ldots \ldots 2.00$

Var. atropurpureum. 2 to $2 \frac{1}{2} \mathrm{ft} \ldots \ldots 2.00$

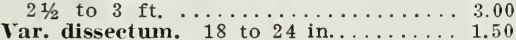

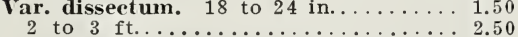

Blood-leaved (sanguineum) 2 to $3 \mathrm{ft} .2 .00$

3 to $4 \mathrm{ft} . \ldots \ldots \ldots \ldots \ldots \ldots \ldots \ldots . \ldots \ldots$

Locust, Rose-flowered (hispida) -

2 to $3 \mathrm{ft} . \ldots \ldots \ldots \ldots \ldots \ldots \ldots \ldots \ldots \ldots . .50$

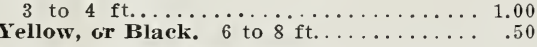

Magnolia, American Varieties-

Acuminata (Cucumber Tree). 3 to $4 \mathrm{ft}$. .75

4 to $5 \mathrm{ft} . \ldots \ldots \ldots \ldots \ldots \ldots \ldots \ldots . \ldots \ldots$

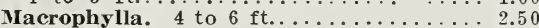

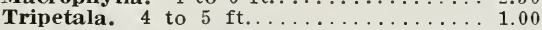

Magnolia, Chinese Varieties-Ball and burlap-

Conspicua, $21 / 2$ to $3 \mathrm{ft} \ldots \ldots \ldots \ldots \ldots \ldots \ldots 2.50$

Lennei. 3 to $4 \mathrm{ft} \ldots \ldots \ldots \ldots \ldots \ldots \ldots \ldots 1.50$

Soulangeana. 3 to $4 \mathrm{ft} \ldots \ldots \ldots \ldots \ldots \ldots 1.50$

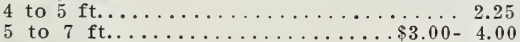

Speciosa. 3 to $4 \mathrm{ft} \ldots \ldots \ldots \ldots \ldots \ldots \ldots \ldots$

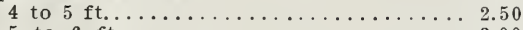

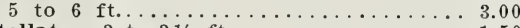

Stellata. 2 to $2 \frac{1 / 2}{\mathrm{ft}} \ldots \ldots \ldots \ldots \ldots \ldots \ldots \ldots \ldots$

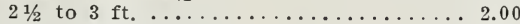

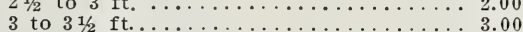

Maidenhair Tree (Salisburia). 6 to $8 \mathrm{ft} . \ldots 1.00$

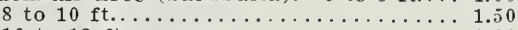

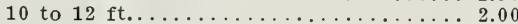

Mulberry, Weeping. 2-yr. head........ 1.50

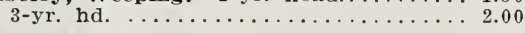

Oak, Golden. 5 to $6 \mathrm{ft} \ldots \ldots \ldots \ldots \ldots \ldots \ldots \ldots$

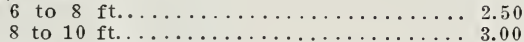

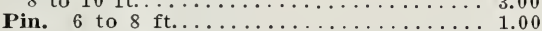

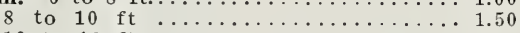

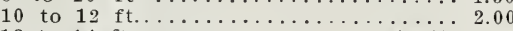
12 to $14 \mathrm{ft} . \ldots \ldots \ldots \ldots \ldots \ldots \ldots \ldots \ldots \ldots \ldots \ldots \ldots+3.00$ Pyramidal (fastigiata). 8 to $10 \mathrm{ft} \ldots \ldots 3.50$

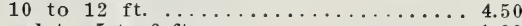

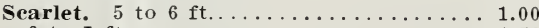

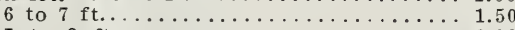

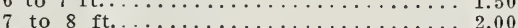

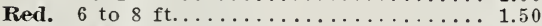

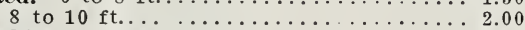

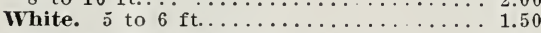

Paulownia (Empress Tree). 6 to $8 \mathrm{ft} \ldots \ldots .1 .00$

Peaches, Double-flowering. 3 to $4 \mathrm{ft}$..... .50 4 to $5 \mathrm{ft} \ldots \ldots \ldots \ldots \ldots \ldots \ldots \ldots \ldots \ldots \ldots \ldots . .50$

Plane, Oriental. 6 to $8 \mathrm{ft} \ldots \ldots \ldots \ldots \ldots \ldots .60$

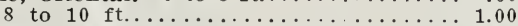

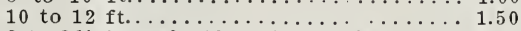
2 to $2 \frac{1 / 2}{2}$ in. cal., 12 to $15 \mathrm{ft}$ high..... 2.50 $2 \frac{1 / 2}{2}$ to $3 \mathrm{in}$. cal., 12 to $15 \mathrm{ft}$. high..... 2.50

Plane, Oecidental. 6 to $8 \mathrm{ft} \ldots \ldots \ldots \ldots \ldots \ldots .75$

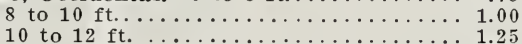

Poplar Abele. 6 to $8 \mathrm{ft} \ldots \ldots \ldots \ldots \ldots \ldots . .75$

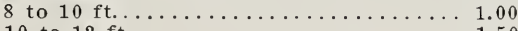

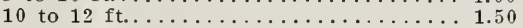

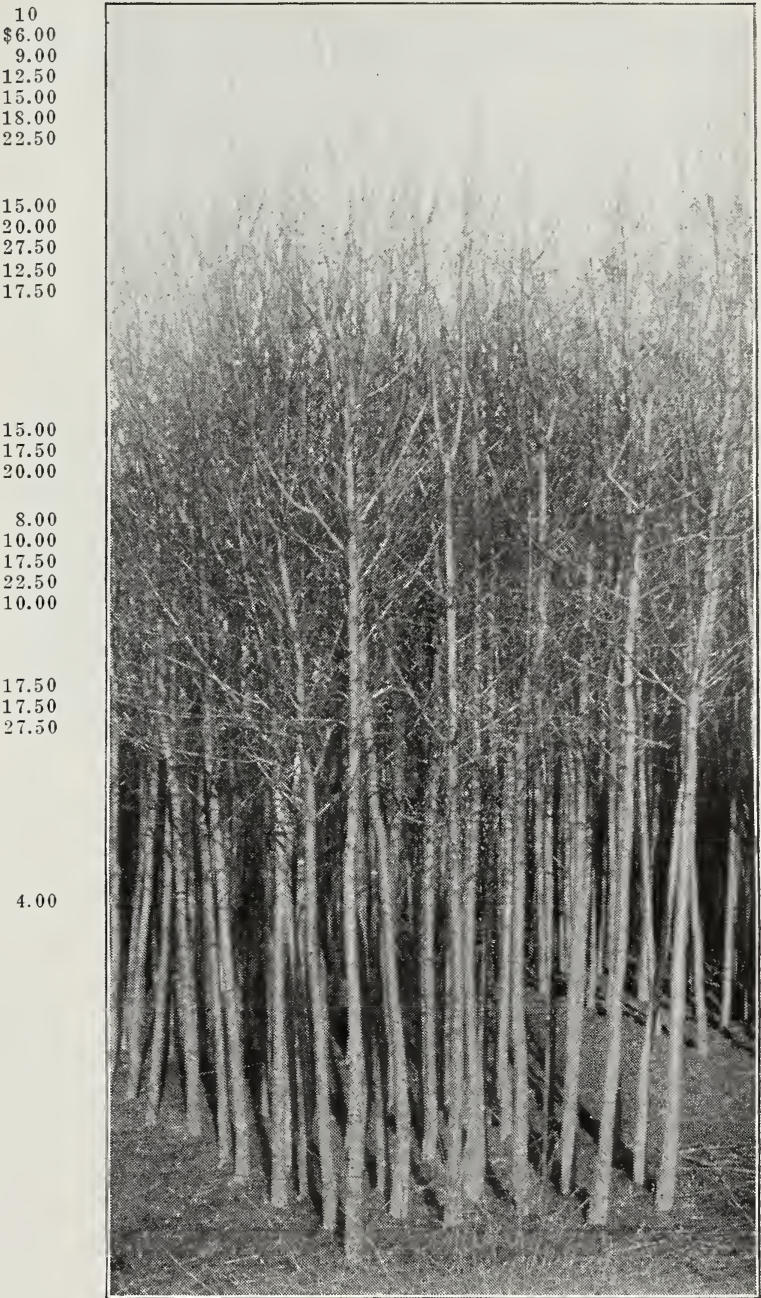

Norway Maples "Heeled in"

These trees have been planted wide apart, which has given room for the development of good tops and straight stocky trunks.

The roots are immense masses of fibres, which insures their rapid growth.

Boleana. 6 to $8 \mathrm{ft}$.

8 to $10 \mathrm{ft}$.

Carolina. 8 to $10 \mathrm{ft}$. .

10 to $12 \mathrm{ft}$.

$\ldots$

Iombardy. 8 to $10 \mathrm{ft}$. .

10 to $12 \mathrm{ft}$.

12 to $14 \mathrm{ft} . \ldots \ldots \ldots$. 3 .

$\$ 0.50 \$ \$ 4.00$

3.50

5.00

8.00

4.00

6.00
10.00

30.00

Sweet Gum (Liquidamber) 5 to $6 \mathrm{ft} \ldots . .1 .00$

6 to $8 \mathrm{ft} . \ldots . .50$

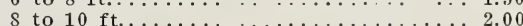

12.50
17.00

Thorn, Flowering. 6 to $8 \mathrm{ft} \ldots \ldots \ldots \ldots \ldots 1.50$

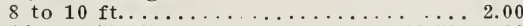

10 to $12 \mathrm{ft}$...................... $\$ 200$

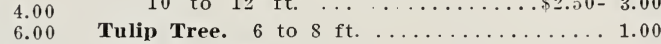

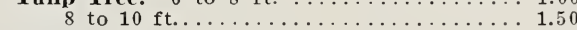

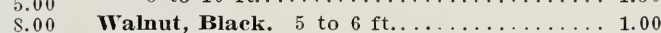

12.00
20.00 $\quad \begin{gathered}8 \\ 8\end{gathered}$

20.00

6.00

S.00

6.00
8.00

12.50
Willow. Rosemary-leaved. 3 to $4 \mathrm{ft} \ldots \ldots . .75$

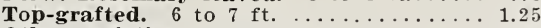
Other varieties. 6 to $8 \mathrm{ft} \ldots \ldots \ldots \ldots \ldots \ldots \ldots \ldots$

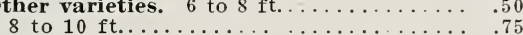

Yellow-wood (Cladrastis). 5 to $6 \mathrm{ft} \ldots \ldots .1 .25$

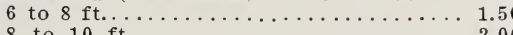

7.50 10.00 6.00

4.00

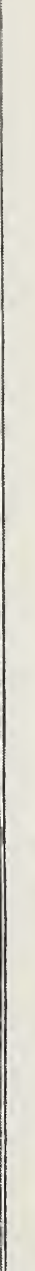




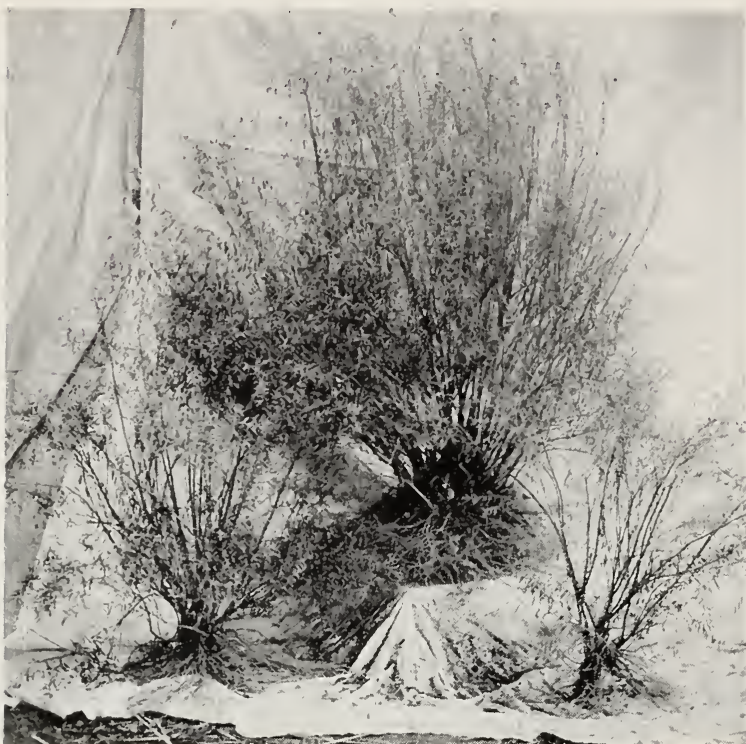

Three Sizes of Spirea Thunbergii

Illustrating the development of both roots and tops by successive transplanting of all shrubs. We have from two to four sizes of most all varieties of flowering shrubs listed below. If the large plant above had not been several times transplanted, the best part of not been several times transplanted, the best part of
the roots would have been left in the ground, since they would have been several feet from the plant.

\section{Flowering Shrubs}

Almond, Flowering. 2 to $3 \mathrm{ft} \ldots \ldots \ldots \ldots$ Each Altheas, in variety. 3 to $4 \mathrm{ft} . \ldots \ldots \ldots \ldots \ldots$

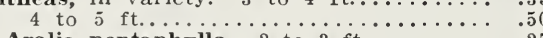

Aralia pentaphylla. 2 to 3 ft.........

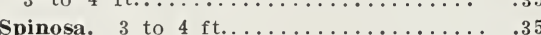

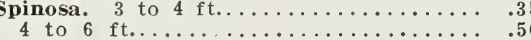

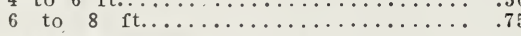

Azalea arborescens. $1 \frac{1}{2}$ to $2 \mathrm{ft}$........ 1.00

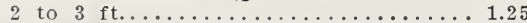

Calendulacea. 2 to $3 \mathrm{ft} . \ldots \ldots \ldots \ldots \ldots \ldots . \ldots \ldots$

Mollis. 15 to 18 in.; 20 to 25 buds...... .50

18 to 24 in.; 25 to 30 buds....................

24 to 30 in.; 30 to 40 buds............ 1.00

Large plants, $\$ 1.50 \mathrm{up}$.

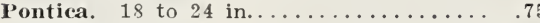

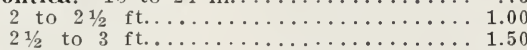

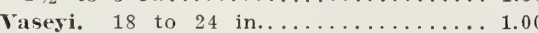

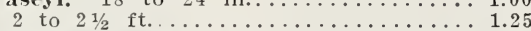

Barberry purpurea. 2 to $3 \mathrm{ft} \ldots \ldots \ldots \ldots . .25$

Thunbergii. 12 to 18 in. $\$ 9.00$ per $100 \ldots .20$

18 to 24 in................. 12.00 per $100 \quad .25$

2 to $21 / 2 \mathrm{ft} .$, bushy.................... 40

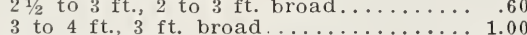

Vulgaris. 2 to $3 \mathrm{ft} \ldots \ldots \ldots \ldots \ldots \ldots \ldots \ldots .25$

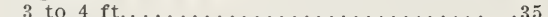

Calycanthus. 18 to 24 in.............................. 25

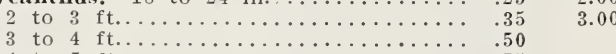

4 to $5 \mathrm{ft}$.

2 to $3 \mathrm{ft} . \ldots \ldots \ldots \ldots \ldots \ldots \ldots \ldots \ldots . . . \ldots \ldots$

Ceanothus Americanus. $1 \frac{1 / 2}{2}$ to $2 \mathrm{ft} . \ldots \ldots$. .3

Clethra alnifolia. 2 to $2 \frac{1}{2} \mathrm{ft} \ldots \ldots \ldots \ldots \ldots .25$

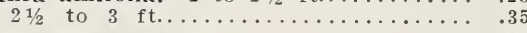

Cornus sanguinea. 2 to $3 \mathrm{ft} \ldots \ldots \ldots \ldots \ldots .25$

Paniculata. 3 to $4 \mathrm{ft} . \ldots \ldots \ldots \ldots \ldots \ldots . .35$

Spaethi. 2 to $3 \mathrm{ft} \ldots \ldots \ldots \ldots \ldots \ldots \ldots \ldots . .50$

Daphne Mezereum. Red. 1 to $2 \mathrm{ft} . \ldots \ldots \ldots \ldots . .50$

White. 1 to $2 \mathrm{ft} . \ldots \ldots \ldots \ldots \ldots \ldots \ldots . .50$
10

$\$ 3.00$

4.50

2.00

3.00

4.00

6.00

7.50

10.00

4.00

6.00
7.50

6.00

8.00

7.50

10.00
2.00

1.20

1.50

\subsection{0}

2.00
3.00

2.00

3.00

3.00

2.00

3.00

2.00

3.00

4.00

6.00

4.00

4.00
Deutzia crenata. 2 to $3 \mathrm{ft}$ Each

Gracilis. 18 to $24 \mathrm{in} . \ldots \ldots \ldots \ldots \$ 0.25$

Gracilis rosea. 2 to $3 \mathrm{ft} . \ldots \ldots \ldots .50$

Lemoinei. 18 to 24 in.......... 25

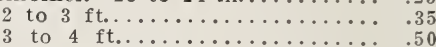

Pride of Rochester. 2 to $3 \mathrm{ft} . \ldots . .25$

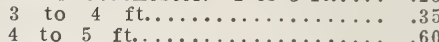

Elaeagnus longipes. 2 to $3 \mathrm{ft} \ldots \ldots$.

Elder, Cut-leaved. 3 to $4 \mathrm{ft} . \ldots \ldots \ldots . .35$

4 to $5 \mathrm{ft} . \ldots \ldots \ldots \ldots \ldots \ldots \ldots . . . \ldots$

Golden-leaved. 3 to $4 \mathrm{ft} . \ldots \ldots \ldots . .35$

4 to $5 \mathrm{ft} . \ldots \ldots \ldots \ldots \ldots \ldots . .50 . . .50$

Euonymus, European. 3 to $4 \mathrm{ft} . \ldots .35$

4 to $5 \mathrm{ft} \ldots \ldots \ldots \ldots \ldots \ldots \ldots \ldots .50 \ldots \ldots$

Alatus. 2 to $21 / 2 \mathrm{ft} \ldots \ldots \ldots \ldots \ldots 1.00$

Americana. 2 to $3 \mathrm{ft} . \ldots \ldots \ldots . .35$

Exochorda. 2 to $3 \mathrm{ft} \ldots \ldots \ldots \ldots$

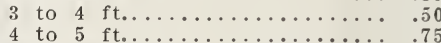

Filbert Purple. 3 to $4 \mathrm{ft} . \ldots . \ldots . .50$

Forsythias, in variety. 2 to $3 \mathrm{ft} . \ldots .25$

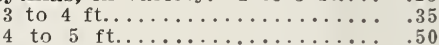

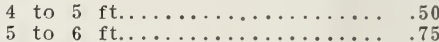

Fringe, Purple. 2 to $3 \mathrm{ft} . \ldots \ldots \ldots . .35$ 3 to $4 \mathrm{ft} \ldots \ldots \ldots \ldots \ldots \ldots \ldots \ldots . .50 \ldots \ldots$

Halesia. 4 to $5 \mathrm{ft} . \ldots \ldots \ldots \ldots \ldots .75$

Honeysuckle, Upright. In variety-

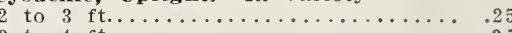

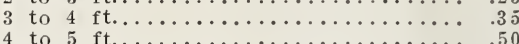

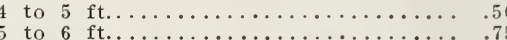

Hydrangea arborescens grandiflora alba- $\begin{array}{lll} & .75 & 6.00\end{array}$

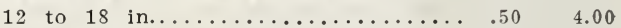

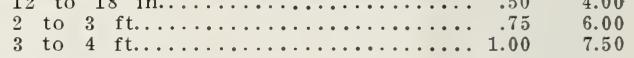

Hydrangea Hortensis. 18 to 24 in....... $.50 \quad 4.00$ 2 to 3 ft............................. 65

Paniculata grandiflora. 18 to 24 in.......25 2.00

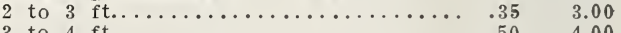

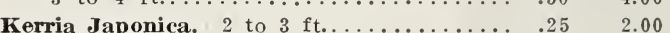

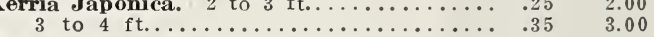

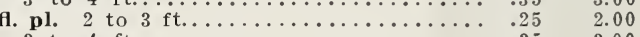

3 to $4 \mathrm{ft} . \ldots \ldots \ldots \ldots \ldots \ldots \ldots \ldots \ldots . .35 \quad 3.00$

Variegated. 18 to 24 in.................. $25 \quad 2.00$

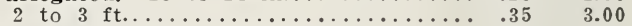

Lilacs, grafted. 2 to $3 \mathrm{ft} \ldots \ldots \ldots \ldots \ldots \ldots . .50 \quad 4.00$

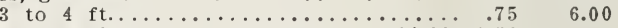

Lilacs, on own roots. Six-year-old plants of choice named varieties.

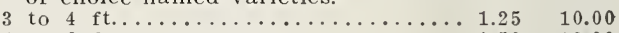

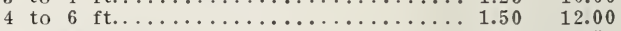

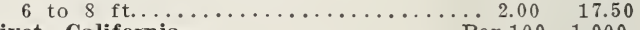
Privet, California-
2 to $3 \mathrm{ft} \ldots \ldots \ldots \ldots \ldots \ldots \ldots \ldots \ldots \ldots \ldots \ldots \ldots \ldots \ldots \ldots \ldots$

3 to 4 ft. ..................... $5.00 \quad 40.00$

3 to 4 ft., transplanted $1911 \ldots \ldots \ldots \ldots 8.00 \quad 70.00$

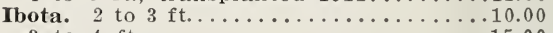

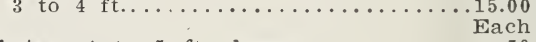

Ibota. 4 to $5 \mathrm{ft}$, heavy.......... .50

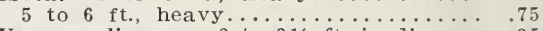

Var. regelianum. 2 to $2 \frac{11}{2} \mathrm{ft}$. in diam...

Amoor River. 2 to $3 \mathrm{ft} . \ldots \ldots \ldots \ldots \ldots . .25$

Golden California. Beautiful-

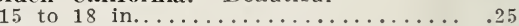

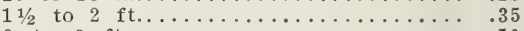

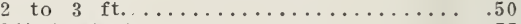

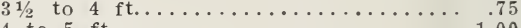

Rhodotypus Kerriodes. 3 to $4 \mathrm{ft}$........ 50

Rhus laciniata-

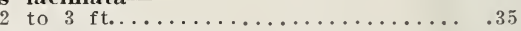

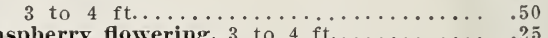

Raspberry flowering. 3 to $4 \mathrm{ft} . \ldots \ldots \ldots \ldots . .25$

Snowball, acerfolium. 2 to $3 \mathrm{ft} \ldots \ldots \ldots \ldots . .50$

Cassanoides. 18 to 24 in............... .5

Dilatatum. 3 to $4 \mathrm{ft} \ldots \ldots \ldots \ldots \ldots .50 .50 . .50$

Dentatum molle, 2 to $3 \mathrm{ft} \ldots \ldots \ldots \ldots \ldots \ldots . .35$

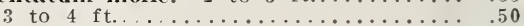

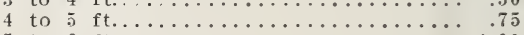

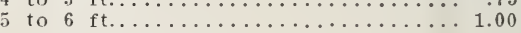




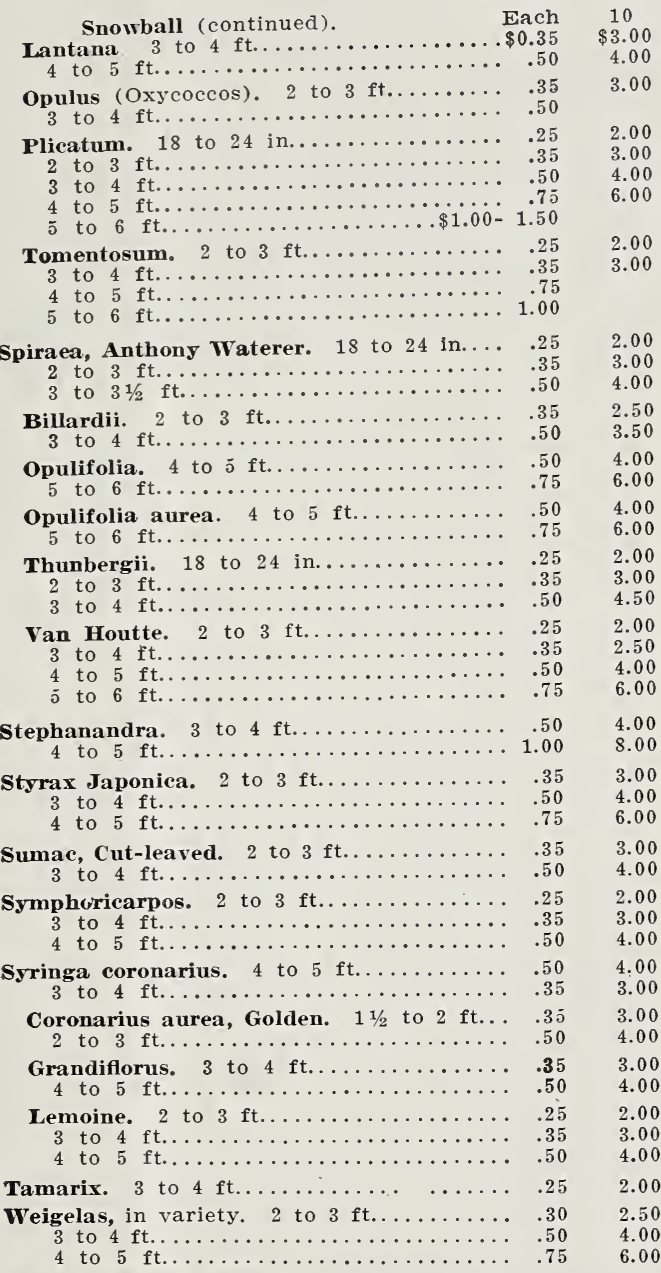

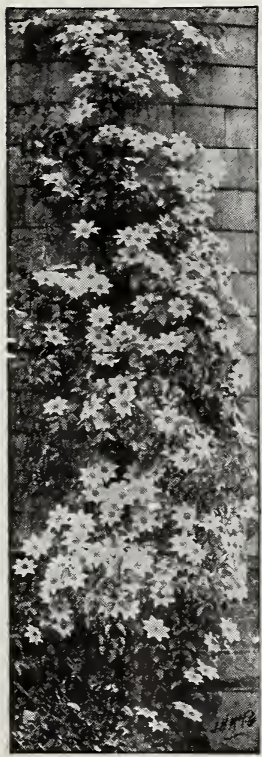

Clematis

\section{PLANS FOR CITY PARKS}

"Personally, I was very much pleased with the plan which you sent and will say that they have given much satisfaction to those interested in them. On this account, I have taken pleasure in recommending your house to many."

"My order arrived Friday in excellent condition. Trees and shrubs exceeded my expectations. Having such fine roots, they surely cannot do otherwise than grow."

"I enclose my check on payment of bill. The trees and plants arrived in good shape and I am sorry I did not give you my whole order."

"I reached my office from the Adirondacks on Saturday. The plants and shrubs came in fine shape, being most admirably packed."

Estimates cheerfully furnished on gardens or other landscape work. Special prices on large lists of stock.

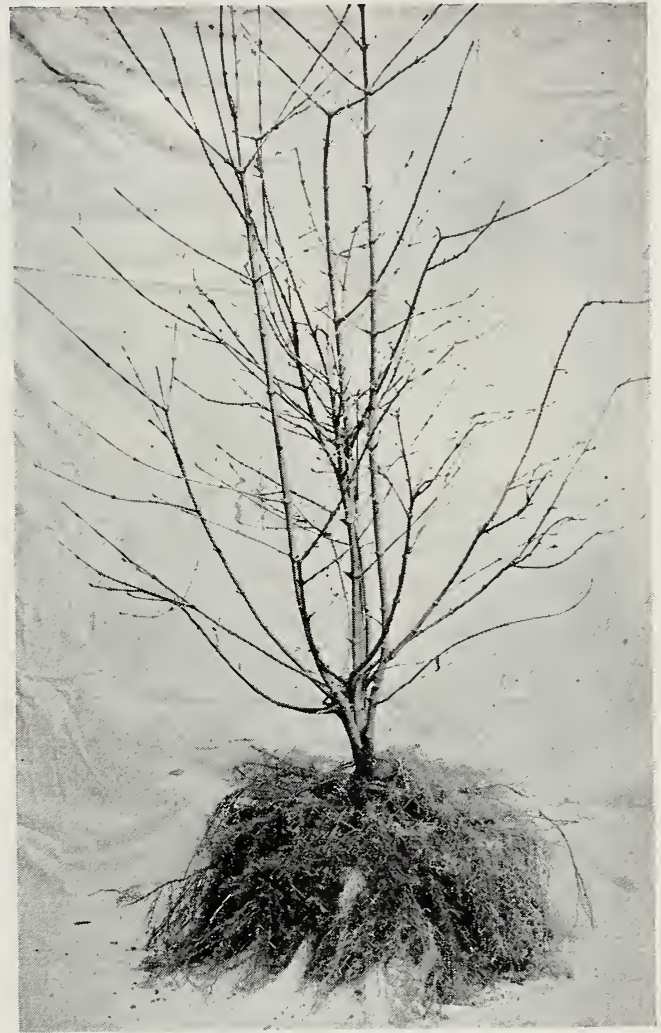

Japan Snowball

5 to $6 \mathrm{ft}$, showing immense development of roots by three transplantings in six years.

\section{Vines}

Actinidia. 4 to $5 \mathrm{ft} . \ldots \ldots \ldots \ldots \ldots \ldots \ldots \ldots \ldots \ldots$ Each 10

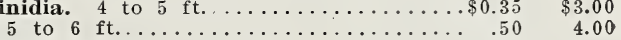

Akebia quinata. 4 to $5 \mathrm{ft} . \ldots \ldots \ldots \ldots \ldots .35 \quad 3.00$

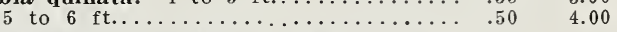

Ampelopsis quinquefolia (Virginia Creep-

er) ...........\$15.00 per $100 \ldots .25 \quad 2.00$

Veitchii (Boston Ivy) -

2 yr. .......... \$12.00 per $100 \ldots .25 \quad 1.50$

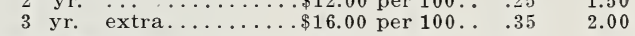

Aristolochia (Dutchman's Pipe)............60 50.00

Bignonia (Tecoma) grandiflora

3 to $4 \mathrm{ft} \ldots \ldots \ldots \ldots \ldots \ldots \ldots \ldots \ldots \ldots \ldots . .50 \quad 4.00$

Radicans. 3 to $4 \mathrm{ft} . \ldots \ldots \ldots \ldots \ldots \ldots . .35 \quad 3.00$

Celastrus scandens (Bittersweet) -

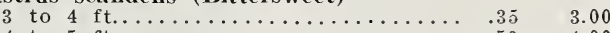

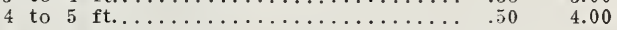

Clematis paniculata. $2-\mathrm{yr} \ldots \ldots \ldots \ldots \ldots \ldots \ldots+.25 \quad 2.00$

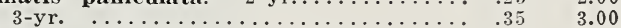

Large-flowered .................40 4.50

Euonymus radicans and variegata.......... .25 2.00

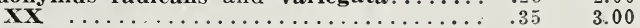

$\mathbf{x x x} \ldots \ldots \ldots \ldots \ldots \ldots \ldots \ldots \ldots \ldots \ldots .50 \ldots \ldots$

Hedera (English Ivy) -

2 to $3 \mathrm{ft} . \ldots \ldots \ldots \ldots \ldots 10.00$ per $100 \ldots .20 \quad 1.50$

Honezsuckle-

3 to 4 ft........\$12.00 per $100 \ldots .20 \quad 1.50$

4 to $6 \mathrm{ft} \ldots \ldots \ldots \ldots \ldots 18.00$ per $100 \ldots .20 \quad 2.50$

Kudzu Vine (Dolichos)............... . .35 3.00

Wistaria, Chinese $\ldots \ldots \ldots \ldots \ldots \ldots \ldots \ldots . .50 \quad 4.00$

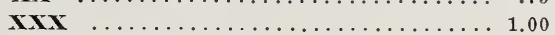




\section{Choice Fruits}

It is a matter of pride with us that we can point to many large estates and fruit farms which we supply with select fruit trees. Although only small space is here given to a list of varieties, we are prepared to ship many other varieties, and have selected below only a few of the choicest kinds, suitable for planting anywhere, In addition to the ordinary size generally offered by nurseries, we have a fine lot of extra sizes in most of the leading varieties, both dwarf and standard, transplanted either in 1910 or 1911 . They have made a fine growth and will save you from two to three years time over ordinary sizes. They have all been carefully inspected by the Department of Agriculture of the State of New York who pronounced them free from all insect pests.

Fruit trees should be well cut back when planted, and currants, gooseberries and peaches should be cut back every spring; some varieties of plums and pears need similar pruning for best results. To insure best treatment, we offer free, with every cash order of $\$ 15$ worth of fruit trees, Bailey's excellent book, "The Principles of Fruit-Growing," 514 pages, 120 illustrations; full directions as to selection of varieties, planting tillage, harvesting and marketing; also renovating old orchards, or "The Pruning Book," by the sam. author. Special rates per 1,000 for orchard planting.

Time of fruiting is given for latitude of New York. *Indieates those grown also as dwarfs.

\section{Apples}

\section{Summer}

Early Harvest. Pale yellow; tender, fine flavor. Latter part of August.

Golden Sweet. Large, yellow; quality fair. August and September.

* Red Astrachan. Tery early, deep crimson, yellowstreaked; tree very hardy and a good bearer. Early August.

Sweet Bough. Large, pale yellow; very juicy and delicious; tree abundant bearer. August.

*Yellow Transparent. Size medium; skin pale yellow, tender, juicy, subacid. August.

\section{Autumn}

* Bismarck. Handsome and showy, color red and yellow; extremely hardy and prolific, and bears very early.

Fall Pippin. Large, yellow, tender and delicious; admirable baking apple; December.

*Fameuse (Snow Apple). Deep crimson; flesh snowy white; one of the finest dessert fruits. November to January.

Gano. Good size, conical; deep red flesh yellow, tender, mild, sub-acid, tree vigorous and prolific. good keeper and shipper. February to May.

* Gravenstein. Large, striped red and yellow; excellent quality. September and October.

Maiden's Blush. Pale yellow, with red cheek, not ery high-flavored; tree erect and good bearer. September and October.

*oldenburg, Duchess of. Streaked with red and yellow; very hardy Russian variety; bears young and abundantly. August and September.

Red Bietigheiner. A rare and valuable German variety. Fruit large to very large; roundish, inclined to conical; skin pale, cream-colored ground, mostly covered with purplish-crimson; flesh white, firm, subacid; with a brisk pleasant flavor. Tree a free grower and abundant bearer. Early fall. September.

*Wealthy. Dark red and yellow stripes; flesh white, vinous, subacid; very hardy. October.

\section{Winter}

*IBaldwin. Well known. bright red, market variety; tree very productive; very popular in the North.

Ben Davis. Large, handsome striped apple, fair quality; tree very hardy and productive.

*Greening. Very popular everywhere; tree vigorous and spreading but often crooked when young: constant bearer; one of the best for cooking. Keeps well until March.

Grimes' Golden. Medium to large size, round, rich golden yellow, sprinkled with light gray dots; flesh crisp, tender, rich and juicy, sprightly. Tree hardy, vigorous and productive. January to April.

* Yubbardson Nonesuch. Tender and juicy; a great bearer; one of the best. November to January.

* King of Tompkins County. Large red apple of finest quality for cooking. tree very hardy, vigorous and good bearer. November to January.

*MeIntosl.. A hardy Canadian sort. Medium, nearly covered with dark red. Flesh white, fine, very tender, juicy and refreshing with peculiar quince-like flavor. A good annual bearer. November to February.

Newtown Pippin. One of the best American Apples, but its success is confined to certain districts and soils November to June. Top-grafted, $75 \mathrm{c}$.
* Northern Spy. Large; yellow, striped red; flesh rich aromatic; keeps until June; tree rapid in growth and a good bearer.

Rambo. Greatly esteemed old variety, streaked red and yellow; flesh tender and mild-flavored; tree vigorous and a good bearer.

Roxbury Russet. Medium size, green and russet color; tree large and a great bearer; keeps until June.

Spitzenburg (Esopus). Large deep red; flesh yellow, crisp and good; does especially well in New York state. November to April.

Stark. Large, roundish; greenish-yellow, much shaded with light and dark red; sprinkled with brownish dots; flesh yellowish, juicy, mild sub-acid; a long keeper and valuable market fruit. January to May.

Stayman Winesap. Dark, rich red, indistinctly striped, but stripe is more pronounced in spicimens less highly colored. Flesh firm, fine grained, crisp, juicy, and very tender; rich sub-acid, quality best.

Sutton Beauty. Large, roundish; skin waxen yellow, striped with crimson; flesh tender, sub-acid, good Tree, a free grower and productive. December and January.

Talman's Sweet. Medium, pale whitish-yellow slightly tinged with red; flesh white, firm, fine grained, and very sweet; hardy tree and productive. November to April.

Twenty Ounce. Very large striped Apple, excellent for cooking and baking; tree a good grower and bearer. October to September.

Wolfe River. An iron-clad, originating near Wolfe River, Wis., fruit large, greenish-yellow, shaded with crimson; flesh white, tender and juicy, with a peculiar pleasant and acid flavor. January to February.

York Imperial (Johnson's Fine Winter). Medium white, shaded with crimson in the sun, juicy, crisp, mild, subacid; tree moderately vigorous and productive. November to February.

\section{Crab Apples}

Fyslop. Beautiful in flower; large crimson. October Montreal Beauty. Large, bright yellow, shaded with red; flesh yellowish, firm, acid. September.

Red Siberian. Red. September and October.

Yellow Siberian. Large, pale yellow, with tint of red. September.

Transcendent. Red and yellow; productive. September.

We offer a grand lot of dwarf apples, pears and plums, transplanted, Spring of 1910. Some of these are, this year, bearing fruit in the nursery.

Description of Dwarf Apples not described in the general list above.

Blenheim Pippin. Excellent, a general farorite. November to February.

Cox's Orange Pippin. Extra fine, one of the best table apples. Crisp and sweet. November to January.

Keswick Codlin. Large, conical, an excellent bearer. Very useful for cooking. August to September.

Ribston Pippin. One of the very best table apples. November to March.

Stirling Castle. Large size, good cropper, good culinary variety. October to November.

Special price on large lists for orchard planting. We offer a fine lot of extra sizes in Peaches in a few hest sorts at $50 \mathrm{c}$ each. 


\section{Prices of Fruits}

No charge for boxing or packing. Five or more of a kind at 10 rate, 50 at 100 rate, 250 at 1.000 rate.

All transplanted Spring, 1910 or 1911.

First class, $i$ to $\& \mathrm{ft} \ldots \ldots \ldots \ldots \ldots . .75 \quad 6.50$

Dwarf, 2 to $3 \mathrm{ft} \ldots \ldots \ldots \ldots \ldots \ldots \ldots \ldots . \ldots \ldots$.5 $4.0 \ldots$

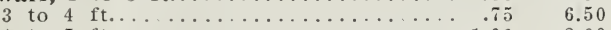

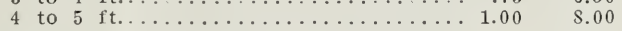

Apricots. First-class, 3 to $5 \mathrm{ft} \ldots \ldots \ldots \ldots \ldots . .50 \quad 4.00$

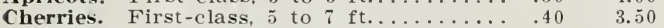

Peaches. First-class, $t$ to $6 \mathrm{ft} \ldots \ldots \ldots \ldots \ldots . .35 \quad 3.00$

Pears. Standard, 5 to $7 \mathrm{ft} \ldots \ldots \ldots \ldots \ldots \ldots . .50 \quad 4.50$

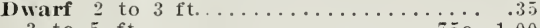

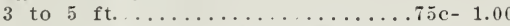

We have a few pears of Kieffer, standard, bearing size, transplanted two years since, beautiful trees, very stocky and with heary tops.

6 to $7 \mathrm{ft}$.

to $9 \mathrm{ft}$.

Eanh $\quad 10$

6.50

10.00

12.50

Beurre Bose and Winter Nelis top grafted .75

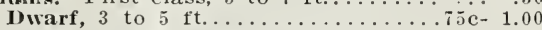

Quinces. First-class, 4 to 6 ft......... .60

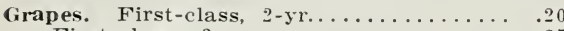

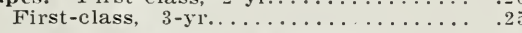

Campbell's Early and Winchell .......... .35

$4-\mathrm{yr}$, transplanted $\ldots . . . . .$.

$\begin{array}{cccc}\text { Currants- } & 10 & 100 & 1,000\end{array}$

First-class, two year.......\$1.00 $\$ 7.00 \quad \$ 60.00$

Perfection

Gooseberriest

Two year $\ldots \ldots \ldots \ldots \ldots \ldots \ldots \ldots \ldots$

Three year $\ldots \ldots \ldots \ldots \ldots \ldots \ldots \ldots . \ldots 2.50 \quad 20.00$

Asparagus ...............\$1.00 per 100

Rhubarb, $\$ 1.00$ per dozen. $100 \quad 1,000$

Blackberries $\ldots \ldots \ldots \ldots \ldots \ldots \ldots \ldots \ldots \ldots \$ 2.50 \quad \$ 20.00$

Blackberry. Erskine Park......... $3.00 \quad 25.00$

This is the hardiest, sweetest and long-

est season of bearing of all varieties. It

has never been known to die back at the

tips even in the severe winters at Lenox.

Mass., where it originated.

Raspberries $\ldots \ldots \ldots \ldots \ldots \ldots \ldots \ldots \ldots 2.50 \quad 20.00$

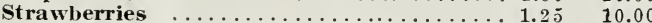

Pot plants July and August......... $3.50 \quad 30.00$

\section{Nut Trees}

We offer a fine lot of English Walnut, 7 to 8 feet high, at $\$ 1.00$ each; 8 to 10 feet at $\$ 1.25$ each.

These trees will soon come into bearing and will
Apples. First-class, 5 to $7 \mathrm{ft} \ldots \ldots \ldots \ldots \$ 0.50 \quad \$ 4.00$

Plums. First-class, 5 to $7 \mathrm{ft} . \ldots \ldots \ldots \ldots \ldots . . . .50$

make beautiful lawn trees in addition to the fruit.

Chestnut, American. 6 to $S$ feet high, $50 \mathrm{c}$ each; $\$ 4.00$ per 10

Spanish, 3 to 4 feet high, $50 \mathrm{c}$ each; $\$ 3.00$ per 10 .

\section{Cherries}

The Cherry succeeds well on dry soils and is susceptible of being trained in a great variety of forms. The sour Cherries are particularly appropriate for dwarfs and pyramids.

\section{SIVEET}

Black Tartarian. Very large, black, of the finest quality; tree good grower and immense bearer. I,ast of June.

Governor Wood. Large white Cherry, shaded with red; hangs well on the tree; middle of June.

Napoleon Bigarreau. Large, pale yellow, red cheek; good bearer; last of June.

Windsor. A seedling originated at Windsor, Canada. Flesh firm and of fine quality; dark red; early July.

\section{SOUR}

Early Richmond. Tery valuable for cooking; tree vigorous, healthy and very productive. June.

May Duke. Well-known, excellent variety; juicy, subacid. Middle of June.

Montmorency. Large, red; 10 days later than Early Richmond; very prolific and hardy.

Reine Hortense. Bright red, of great excellence; nearly sweet.

\section{Pears}

\section{SUMMER}

*Bartlett. One of the best known Pears, with a rich. musky flavor; abundant bearer even when young; middle of September.

Tyson. Good size, juicy and sweet; tree vigorous and rapid grower, abundant bearer. August.

\section{AUTUMN}

Bose (Beurre Bosc). Large, russety Pear, with long neck; highly flavored and delicious; September to October.

*Duchess d'Angouleme. One of the largest, good Pears which attains its perfection as a dwart.

Howell. Large, yellow, sweet and delicious; very hardy and productive. September and October.

Kieffer. Large, golden yellow, often tinted with red; very vigorous and productive, even when young. October and November.

*Seckel. Small, but of the highest flavor; tree strong grower and good bearer.

*WVorden Seckel. Seedling of Seckel, with larger fruit and better keeper. October to December.

Sheldon. Large round, russet and red; very juicy; poor keeper. October.

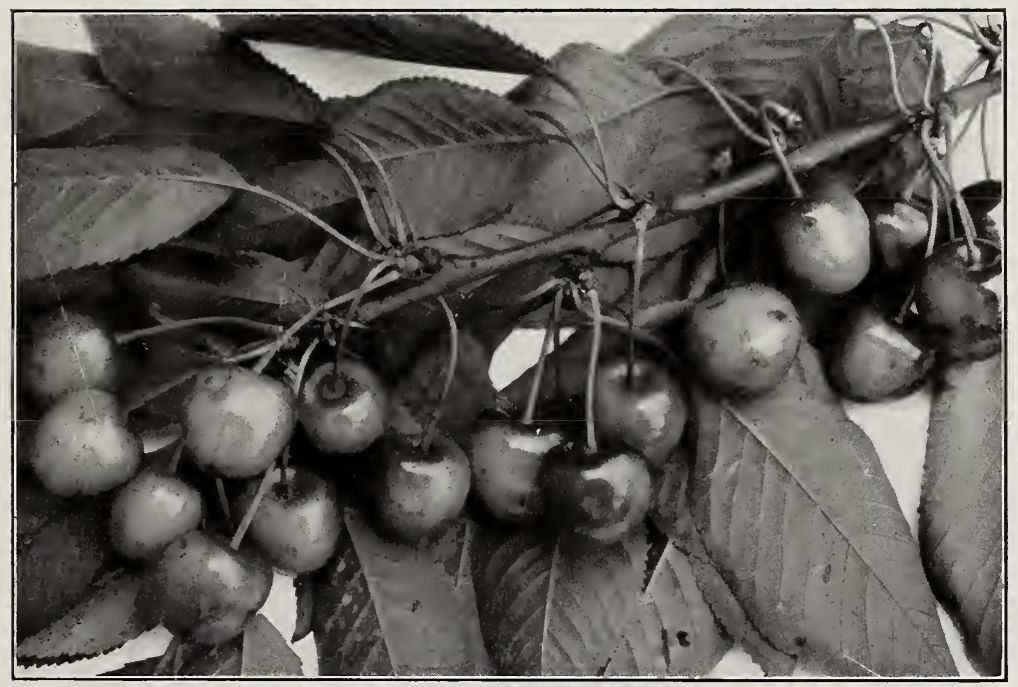

* Anjou. Large, handsome, buttery, with a slight vinous flavor: tree vigorous and an excellent bearer; keeps until Christmas.

*Lawrence. Golden yellow, medium size a $\mathrm{nd}$ abundant bearer. November to January.

Winter Nelis. Medium size, duil russet; rich fine flavor, good bearer. November to January.

P. Barry. Orange-yellow, dotted with russet; flesh juicy, even-grained a n d rich.

\section{Plums}

SELECTED, FIRST-CLASS

*Coe's Golden Drop. Light yellow, firm and white. Last of September.

German Prune. Medium size. purple and rich; very productive. September.

Grand Duke. Large, violet-red. September and Oc-

Imperial Gage. Yellowish green; flesh rich and sweet; very productive. Governor Wood. 
*Shropshire Damson. Medium, dark purple; excellent for preserving. An abundant bearer.

Yellow Egg. Very large, yellow Plum; rather coarse, but good for cooking; good bearer. Last of August.

\section{JAPANESE VARIETIES}

* Abundance. Large amber; flesh yellow and sweet very productive. July.

*Burbank. Large, cherry red, good bearer; market variety. Early September.

*October Purple. Considered by Mr. Burbank as one of his best hybrids; large purple, with yellow flesh very late.

*Wickson. Large, glowing carmine; flesh white, firm and delicious; upright, stately grower. September.

\section{Peaches}

\section{SELECTEI) TREES, FIRST-CLASS}

No class of fruit brings such quick and valuable returns as do the Peaches, if they are properly cared for and no class suffers more from neglect than this. The ground should be kept cultivated and occasionally given a dressing of wood ashes. Pruning must be annual and rigid cutting back the previous year's growth in March from one-third to one-half. This is a quick method of thinning the fruit, for if the trees have made a good growth, as they should, under proper culture, they will set two or three times more fruit than they can bring to maturity. As a result, the fruit is premature and the tree is likely to die of overproduction of seed. When planted, the tree should be cut back severely, leaving only one or two eyes to each branch.

*Belle of Georgia. Very large, skin white with red cheek; flesh white, firm and of excellent flavor. Rapid grower, very prolific, fine shipper. Ripens with Crawford's Early.

*Carman. Large, oblong, pale yellow, with deep blush; skin very touch, tender, juicy and fine flavor; very hardy and heavy cropper. August.

*Chair's Choice. Deep, yellow, red cheek, firm; a few days earlier than Smock. September.

*Crampion. Early, large, white, with red cheek; rich and juicy. Early August.

*Crawford's Early. Large, yellow Peach of excellent quality; tree vigorous and productive. Last of August.

*Crawford's Late. Superb yellow Peach, of large size and excellent quality; great bearer. Middle of September.

*Crosby. Medium size, orange-yellow and a good quality; ripens between Crawford Early and Late.

*Elberta. Very large and handsome; flesh yellow, juicy and of excellent quality; one of the best. Ripens between Crawford Early and Late.

* Foster. Large, yellow; resembling Crawford Early, but of better quality, ripening a little earlier.

*Greensborc. A large, beautifully colored early peach, ripening with Amsden. Flesh white, juicy and excellent. One of best early peaches.

*Hill's Chili (Longhurst). Medium, deep yellow, shaded with dark red; juicy melting, vinous; hardy, vigorous and productive. A good market sort. First of September.

*Morris White. Medium size, creamy white, tinged with red; flesh white; excellent flavor; early September.

*Mountain Rose. Large, red Peach, with white flesh; juicy and good. Excellent for early market.

*oldmixon Free. Large. white and red; flesh juicy and rich. A valuable hardy and productive variety, succeeding Crawford's Early.

*River's Early. Large, creamy white, with delicate pink cheek; excellent flavor; one of the finest very early varieties.

*Steven's Rareripe. White Peach of excellent quality; good bearer. Middle of September.

* Stump the World. Red and white, good size; quality fair, but very productive. Middle of September.

We offer the following June buds, strong trees, 3/4" high, at $20 \mathrm{c}$ each, $\$ 1.50$ per $10, \$ 12.00$ per 100 . Elberta, Crawford's Late, Crawford's Early, Belle of Georgia, Champion, Stump.

\section{Apricot}

Where the Apricot is hardy, it is of great value, coming as it does between Cherries and Peaches.

*Alberge de Montgamet. Size medium; early, hardy.
*Moorpark. One of the largest and finest; flesh orange and very delicious.

*Harris. Large, golden yellow fruits. Early July.

\section{Quinces}

* Orange. Large, round, golden yellow; very producive. Ripe in October.

* Rea's Mammoth. Large, fine variety of the Orange Quince; vigorous and productive.

\section{Hardy Grapes BLACK VARIETIES}

Campbell's Early. Clusters large and compact; flesh firm and tender; seeds few; quality rich, slightly vin ous; ripens very early and keeps a long time.

Concord. A well-known and favorite variety; very hardy and productive; succeeds well everywhere.

Moore's Early. Bunch medium; berry large, pulpy and of medium quality; vine hardy and moderately prolific. Desirable for an early crop.

Worden. Seedling of the Concord, but ten days earlier. Superior to it in flavor, but does not bear sh!pping so well.

\section{RED VARIETIES}

Agawam (Rogers No. 15). Bunches very large un der good culture; berries large, sweet and tender. Vine a good grower and very productive. Ripens early.

Brighton. Dark red, of the best quality. Equal to the Delaware, but much larger both in bunch and berry early vigorous and productive.

Delaware. Bunch small and compact; berries small, sweet and vinous; vine slender, but perfectly hardy to the Great Lakes.

Gaertner (Rogers' No. 14). Bunches large; berries very large, light red, tender, sweet, pleasant; very showy; vine vigorous and productive.

Lindley (Rogers' No. 9). Color a rich shade of red; flesh tender, with rich, aromatic flavor: ripens soon af ter the Delaware; vigorous and productive.

Salem (Rogers' No. 53). Bunch large and compact; flesh tender and juicy; ripens with Concord. One of the most popular and productive.

\section{WHITE VARIETIES}

Moore's Diamond. Bunch large; berry medium, yellowish tinge when ripe; very juicy and of good quality: vigorous and fruitful.

Niagara. Bunch large and compact; color pale green, changing to yellow when fully ripe. The flesh is tender, sweet and nearly equal to the Concord; ripens with that variety. The most popular white.

Pocklington. Bunch medium; berry large, slightly golden when fully ripe; quality fair; vine hardy; vigorous and productive. It ripens after Concord.

Winchell (Green Mountain). The earliest white grape; berry and cluster good size; excellent flavor vigorous and productive.

\section{Blackberries}

Plant in rows 6 feet apait, 3 feet apart in the row. In midsummer, when the canes attain a height of 4 feet, pinch off the tips, which will cause them to send out side shoots and become more stocky. To keep the bed in good condition, the old, weak and decayed wood should be cut out every season, leaving four or five of the strongest in each hill.

Agawam. Medium size; jet-black sweet, melting to the core; fine early variety.

Erie. Fruit large and of good quality; an early, vigorous and productive variety.

Rathbun. Berries extra large, jet-black and of good quality. It propagates itself like the Blackcap Raspberry from the tips of the branches.

Snyder. Fruit medium size, sweet and melting to the core; exceedingly hardy and productive.

Wilson's Junior. An early variety of good quality.

BLACKBERRY, ERSKINE PARK SEEDLESS

It originated on the Westinghouse estate in the Berkshires, at an elevation of 1,000 feet above sea level. The superintendent of the estate, Mr. Norman, writes as follows: "This Blackberry, sported from Kittatinny, was first brought to my notice by reason of its hardiness. We always tie the canes up to their fruit-stakes the never protect them at all, and, as you know, they fruit right out to the tips of 6 -foot canes. I do not grow any other variety, for its long fruiting season enables me to trust to that variety alone. The fruit is the largest berry I know, fine flavor, no core, no seeds." 


\section{Raspberries}

Culture same as that of Blackberries. Blackcap varieties should be shortened to within 6 or 8 inches of the main stock in spring.

\section{RED VARIETIES}

Columbian. Fruit very large and purple; robust, hardy and very productive.

Cuthbert. Medium to large; deep, rich crimson; firm and of good quality. One of the best medium to late varieties.

Marlboro. Very early and hardy; fruit crimson and of good quality.

\section{RASPBERRY, ERSKIYE PARK FVERBEARING}

This berry does not begin to fruit until the ordinary varieties are through, fruiting on the new canes and continuing right up to frost. The berries are large, tine and of excellent flavor. As to hardiness, it has stood 20 degrees below zero without protection. Originated at Lenox, Mass.

\section{BLACKCAPS}

Gregg. Large and of excellent quality; season medium; a vigorous grower and very productive.

Kansas. Tery large and firm, and of excellent quality; hardy and very prolific; one of the best varieties.

\section{Strawberries}

Plant in beds 4 feet wide with an alley of 2 feet between them. Plant three rows in each bed, 15 inche apart in the row. For field culture, the rows should be 3 feet apart. Plant in early spring on good, fertile, sandy loam for best results. Pot plants set in July or August will produce a crop the following season. A light cover of stable litter in winter after the ground is frozen is very beneficial, but great care must be used not to put on too much or too early and to remove the
covering in spring as the plants start to grow. New covering in spring as the plants start to grow. New
beds should be planted every other year, as two crops from a planting is all that is profitable. The varieties marked " $\mathrm{P}$ " have pistillate or imperfect flowers, and must be planted near other varieties in order that the flowers may be fertilized.

Brandywine. Large, conical form and of good quality. Very prolific; valuable old variety.

Bubach. (P.) Fruit large, roundish, scarlet and moderately firm; fair quality; plant a strong grower and early to medium.

Gladstone. Fruit large and of fine quality; plant healthy, vigorous and very productive; medium to late one of the best.

Marshall. Very large, dark crimson; firm and of excellent quality; plant vigorous and productive; medium to late. One of the best varieties for home use or market.

Michel's Early. Berry medium to large, bright crimson, firm and of fair quality; plant a strong grower exceedingly early and productive.

McKinley. Very large, conical, sometimes flattened; color crimson. On account of its vigor and great pro-
ductiveness we recomend it for home use or market; ductiveness we
medium to late.

Nick Ohmer. Cone-shaped berries of large size; crimson; flavor rich and a good shipper; medium to iate.

President. (P.) Very attractive, large, red berries, dimpled at ends; very rich and meaty; late and productive.

\section{Currants}

\section{TIYO-YEAR-OLD PLANTS, FIRST-CLASS}

Plant either in spring or fall, in rows 6 feet apart, 3 feet apart in the row. The fruit is greatly improved by cutting out the weak growth and cutting back the previous year's growth one-third to one-half. To de- stroy the Currant worm, dust white hellebore one part, flour two parts, on the bushes when wet with dew part, the leaves are fully expanded in spring. One application is a sufficient preventive of insect attack.

Black Naples. The best black variety, large and excellent.

Cherry. Fruit of very large size and very tart; plant vigorous, but not as productive as some of the other varieties.

Fay's Prolific. Probably the best red Currant; it has been planted very extensively and given general satisfaction. Less acid than the Cherry and of excellent flavor and very productive.

Perfection. (New.) Berry larger than Fay's, clusters averaging longer; red, rich, mild sub-acid. This fruit was the first to receive the $\$ 50$ Gold Medal of the Western New York Horticultural Society, one of the most conservative societies in the country.

White Grape. The best white variety; very large and of mild flavor; excellent table variety.

\section{Gooseberries}

Two- and three-year-old plants first-class

Require the same culture as Currants, and are very useful not only when freshly picked, but are excellent for preserving. They should be allowed to become thoroughly ripened before picking.

Columbus. This is one of the most valuable introductions of recent years in small fruits, and it fully sustains the high opinion first formed of it. The fruit is of largest size, handsome, of a greenish-yellow color, and the quality is excellent. The plant is vigorous and productive and does not mildew. It merits a place in every garden.

Downing. Medium size, light green, of good quality. A strong grower and productive.

Industry. An English variety, large, dark red, rich, sweet and of good flavor, strong grower and very productive.

Red Jacket. (Josselyn.) Large, red American Gooseberry.

\section{Asparagus}

Prepare the ground by trenching to the depth of 2 feet, mixing each layer of soil, as turned over, with 2 or 3 inches of well-rotted manure. For private use, or for marketing, on a small scale, beds should be formed 5 feet wide, with three rows planted in each-one in the middle and one on each side a foot from the edge, the distance of the plants in the rows, 9 inches; the alleys between the beds should be 2 feet wide. In planting, a line is set and a cut made, a little slanting, to the depth of 6 or 8 inches, according to the size of the plants. The plants are then laid against the side of the trench at the distance already named-9 inchescare being taken to properly spread the roots. The crown or top of the plant should be covered about 2 inches. In a week or two after planting, the beds should be touched over lightly with a sharp steel rake, which will destroy the germinating weeds.

Barr's Mammoth. Large green variety, excellent for a market sort.

Columbian Mammoth. A vigorous white variety of excellent quality.

Conover's Colossal. Large shoots; of vigorous growth.

Palmetto, Larger than the Conover's and a heavier yielder.

\section{Rhubarb}

Plant 3 feet apart each way. Fertilize well late in the fall, spading in the fertilizer in the spring.

Iyatt's Linnaeus. Large, early, tender.

\section{INDEX}

Page

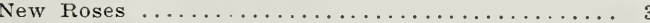

Select Everblooming Roses............... 4

Hybrid Perpetuals ...................

Tree Roses ......................... 6

Miscellaneous $\ldots \ldots \ldots \ldots \ldots \ldots \ldots \ldots \ldots \ldots \ldots \ldots$

Climbing Roses ..................... 8

Roses for Greenhouse..................... 9

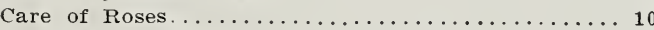

Hardy Perennials ...................11-15
Page

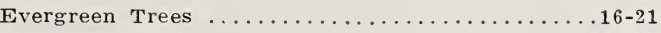

Evergreen Shrubs ..................22, 23

Deciduous Trees ........................ 25

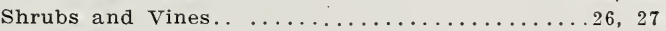

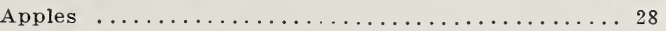

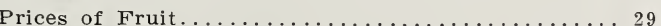

Cherries, Pears, Plums ................. 29

Peaches, Grapes ...................... 30

Apricots, Quinces, other fruits............... 31 



\section{S. G. HARRIS, TARRYTOWN, N. Y.}

The use of this ORDER SHEET will insure the prompt and correct filling of your order

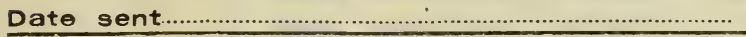

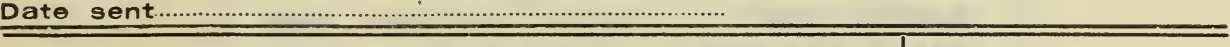

Namio

Post Office Address

Express Address

(if different from

P. O.)
No.

Rec'd

State

Shipped

By

1912

AMOUNT ENCLOSED

Ship about

Express

VARIETIES

STRONG EXTRA SELECTED HYBRID PERPETUALS

ALFRED COLOMB

ANNE DE DIESBACH

BARON DE BONSTETTIN

BARONESS ROTHSCHILD

BEN CANT

CLIO

EARL OF DUFFERIN

FISHER HOLMES

FRANCOIS MICHELON

FRAU KARL DRUSCHKI

GENERAL JACQUEMINOT

HUGH DICKSON

JEAN LIABAUD

JOHN HOPPER

LADY HELEN STEWART

LA ROSIERE

MABEL MORRISON

MADAME GABRIEL LUIZET

MAGNA CHARTA

MARCHIONESS OF LONDONDERRY

MARGARET DICKSON

MARGUERITE DE ST. AMANDE

MARIE BAUMANN

MARSHALL P. WILDER

MERVEILLE DE LYON

LS

$\$ 035$

35

35

35

35

35

35

35

35

35

35

35

35

35

35

35

35

35

35

35

35

35

35

35

35

35

MRS. GEO. DICKSON

40

40

40

35

35

35

ULRICH BRUNNER

See Prices per dozen and per 100, page 4. 
ALICE GRAHAME

ANTOINE RIVOIRE (Mrs. Taft)

BALDWIN (Helen Gould)

BABY RAMBLEP.

BARDOU JOB

BELLE SIEBRECHT

BESSIE BROWN

BETTY

CAPTAIN CHRISTY

CARINE

CAROLINE TESTOUT

CORALLINA

COUNTESS OF GOSFORD

DOROTHY PAGE ROBERTS

DEAN HOLE

DUCHESS OF WESTMINSTER

ETOILE DE FRANCE

EARL OF WARWICK

ELIZABETH BARNES

GEN. MAC ARTHUR

GLADYS HARKNESS

GRACE DARLING

GRACE MOLYNEUX

GUSTAVE REGIS

GRUSS AN TEPLITZ

HARRY KIRK

HIS MAJESTY

JOHANNA SEBUS

J. B. CLARK

KAISERIN AUGUSTA VICTORIA

KRONPRINZESSIN CECILIE

KILLARNEY

KONIGIN CAROLA

LADY BATTERSEA

LADY ALICE STANLEY

LADY URSULA

LADY ASHTOWN

LA FRANCE

LA TOSCA

LAURENT CARLE

LYON-ROSE

MABEL DREW

MADAM ABEL CHATENAY

MADAM JOS. COMBET

MADAM JULES GROLEZ

MADAM MELANIE SOUPERT

MADAM RAVARY

MARGARET

MAMAM COCHET

MARGARET MOLYNEUX 
MFS. C. CURTIS HARRISON

MRS. FOLEY HOBBS

MRS. FRED STRAKER

MRS. LEONARD PETRIE

MRS. WALTER EASLEA

MRS. WILFORD LLOYD

MY MARYLAND (1 year 50c) 75

OTTO VON BISMARK $\quad 75$

PERLE D'OR

PRINCE DE BULGARIE 50

SOUVENIR DE LA MALMAISON 35

SOUVENIR DE PIERRE NOTTING 40

SOUVENIR DU PRESIDENT CARNOT

VISCOUNTESS FOLKSTONE 40

WHITE COCHET $\quad 40$

WHITE KILLARNEY 50

WILLIAM SHEAN $\quad 50$

WM. R. SMITH $50 \mathrm{C}$

STANDARD ROSES

We otfer a grand collection of Rose Trees on Rugosa stock in the best varietles of hybrid Teas and Hytrid Perpetuals. XX size, 3 to 5 plants, S1.50 each: 6 or more plants, at \$1.25 each. $X$ size, 3 to 5 plants. S1.25 each; 6 or more, $\$ 1.00$ each. Crimson Rambler, Baby Rambler and Dorothy Perkins at the following prices, namely: Crimson Rambler, 2-year, 75 cents; 3 -year, S1.50; 4-year, \$2.00. Dorothy Perkins, 2-year, \$1.00; 3-year, \$2.00. Baty Rambler, 2-year, \$1.00; 3-year, \$1.50. Lady Gay, 3-year, $\$ 2.00$.

ALFRED COLOMB

ANNE DE DIESBACH

ANTOINE RIVOIRE

BABY RAMBLER

BARON DE BONSTETTIN

BELLE SIEBRECHT

CAROLINE TESTOUT

CRIMSON RAMBLER

DOROTHY PERKINS

ETOILE DE FRANCE

FRAU KARL DRUSCHKI

GRUSS AN TEPLITZ

KAISERIN AUGUSTA VICTORIA

KILLARNEY

LADY GAY

MAGNA CHARTA

MAMAN COCHET

MRS. JOHN LAING

MRS. R. G. SHARMAN-CRAL:FORD

PAUL NEYRON

SOLEIL D'OR

WHITE COCHET

ZEPHERINE DROUHIN

CLIMBING ROSES

AMERICAN PILLAR

ARDS ROVER

BLUE ROSE (3-yr., 75c)

CARMINE PILLAR

CLIMBING CAROLINE TESTOUT

CLIMBING K. A. VICTORIA

CRIMSON RAMBLER 
COROTHY PERKINS, 3 yr., 50c.

EVERGREEN GEM

FLOWER OF FAIRFIELD

GARDENIA

HIAWATHA

LADY GAY, 3-yr., 50c.

$35 c$

MINNEHAHA, 3-yr., 50c.

$35 \mathrm{c}$

SETIGERA, 3-yr., $50 \mathrm{c}$.

$35=$

TAUSENDSCHON

TRIER

WICHURAIANA

WEDDING BELLS

ZEPHERINE DROUHIN

MOSS ROSES

BLANCHE MOREAU

GRACILIS

CRESTED MOSS

SALET

WHITE BATH

ALBA

RUGOSA ROSES

ATROPURPUREA

DELLE POITEVINE

BLANC DOUBLE DE COUBERT

CONRAD F. MEYER

MADAM GEORGES BRUANT

RUBRA, 3-yr., 50c.

MISCELLANEOUS ROSES

AUSTRIAN COPPER

CABBAGE OR CENTIFOLIA

COQUETTE DES ALPES

CLOTHILDE SOUPERT

35

HARRISON'S YELLOW

35

40

MIGNONETTE

PERSIAN YELLOW

RUBIGINOSA

REMARKS

Varieties offered at 35 cents............ per 12, $\$ 3.50$; per 100, $\$ 25.00$ Varieties offered at 40 cents ........... per 12, 4.00 ; per $100,30.00$ Varieties offered at 50 cents. ............... 12, 5.00 ; per $100,35.00$ Varieties offered at 75 cents $\ldots \ldots \ldots \ldots \ldots \ldots \ldots \ldots \ldots \ldots$ per 12, 7.50 Six at dozen rate, fifty at one hundred rate, provided not less than three of a kind are ordered. 



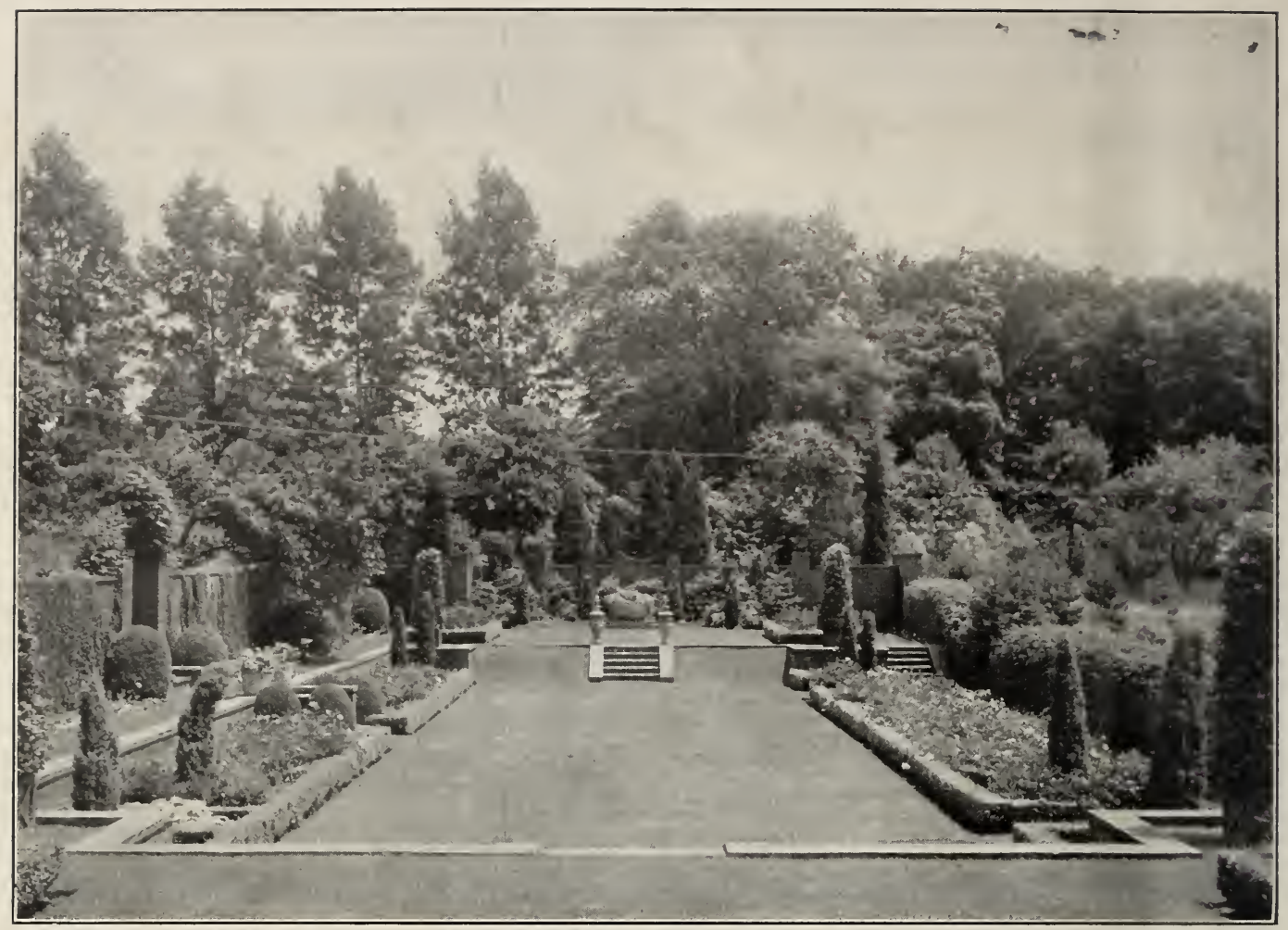

Formal Sunken Garden

\section{Rosedale Nurseries}

Our Nurseries were started in order to produce high-grade trees, which we sometimes found it difficult to buy for our landscape work. Most nurserymen either will not go to the expense of transplanting trees as often as they should be, or grow them so close that the trees do not have room to develop into shapely specimens. We frequently transplant all our trees, which develops a root system capable of insuring the successful and rapid growth of stock when it is planted by our customers. Constant attention is also given to shape trees into symmetrical form, protecting them against insect enemies, and thorough cultivation to make them strong and healthy. That we have been successful in producing stock of high quality is recognized by many of the largest buyers, who often, in addition to their own orders, send us customers from among their friends. One client at Ardsley-on-Hudson has sent us no less than five others; one from Mill Neck, L. I., no less than six.

\section{Landscape Department}

So much depends upon the intelligent selection of varieties and harmonious design in planting to make a landscape picture, that we consider this department of our work quite as important as getting together the very best material. The landscape should present pleasing pictures from various points of view-from the different living-rooms as well as from different positions on the grounds, arrangement for color effect, space for vistas and the screening of unsightly objects-but all in unity of design. This result can be attained only where one has had wide experience and observation, and is thoroughly familiar with the material which he uses. The landscape architect must have an eye to the beautiful. He must have a knowledge of agriculture, horticulture, entomology, surveying and drawing. Through correspondence with our customers, we give much valuable information in addition to that found in our Catalogue, but those contemplating planting to any extent should begin with a planting plan, drawn to scale, in which every tree and shrub is definitely located.

We maie a specialty of designs and have furnished plans for many of the most beautiful places on the Hudson and elsewhere. We are prepared to renovate old estates make planting plans for new ones, and in many other ways assist our patrons to the highest development of their grounds. To those in the vicinity of New York we make a preliminary visit without charge. Those at a distance should send us a sketch of their grounds with dimensions, points of conıass, location of buildings, trees, etc. From these data, we make a planting plan, drawn to scale, at a moderate cost.

By so doing, our clients would save expense and disappointment, because, without expert advice, planters are apt to select material for planting which will not thrive in a given locality; or, those not familiar with the ultimate sizes of trees and shrubs are apt to use two or three times the number required for the best results. 